\title{
Helen Hunt Jackson's Ramona: A Critical Edition
}

\author{
Caitlin Rose Conley \\ Colorado Springs, Colorado
}

B.M.A., DePauw University, 2011

A Thesis presented to the Graduate Faculty of the University of Virginia in Candidacy for the Degree of Master of Arts

\section{Department of English}

University of Virginia

May 2014 


\section{Table of Contents}

Acknowledgements $\ldots \ldots \ldots \ldots \ldots \ldots \ldots \ldots \ldots$ ii

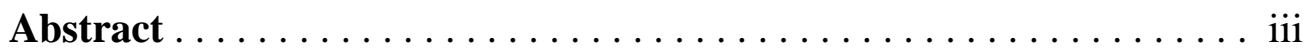

Introduction to the Critical Edition $\ldots \ldots \ldots \ldots \ldots \ldots \ldots$ iv

Historical Commentary ...................... iv

Textual Commentary ......................

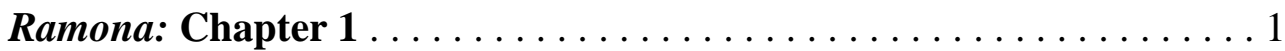

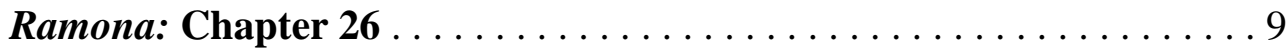

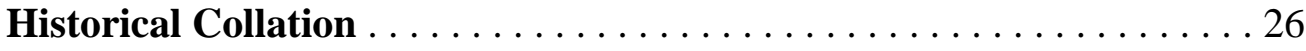

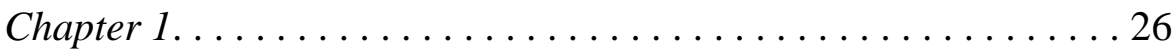

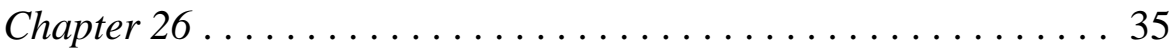

Textual Notes. . ........................ 53

Collation of Paragraph Breaks . . . . . . . . . . . . . . 68

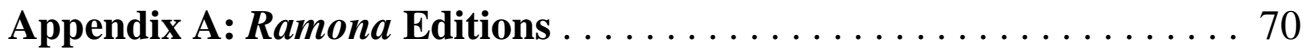

Appendix B: Descriptive List of Editions, 1884-2014 . . . . . . . . 75

Works Cited $\ldots \ldots \ldots \ldots \ldots \ldots \ldots \ldots \ldots \ldots \ldots \ldots \ldots \ldots \ldots \ldots \ldots \ldots \ldots \ldots$ 


\section{Acknowledgements}

I have many people to thank for supporting me and helping me to bring this project to fruition. I am very grateful to have had such a wonderful advisor in David Vander Meulen; I learned so much from his advice and I would have been lost without his support. I owe a great deal of my project's success to the Special Collections department at the Colorado College Tutt Library in Colorado Springs. Thanks especially to Jessie Randall for sharing your expertise with me on Helen Hunt Jackson, as well as your images of and report on the changing editions of Ramona. The Albert and Shirley Small Special Collections Library staff at the University of Virginia was always friendly and helpful, and made my hours of research there that much more delightful. Thank you also to the University of Virginia Rare Book School and Tess Goodman for helping me to access your copies of Ramona. My friend Stephanie Kingsley was always a great support. I enjoyed our brainstorming and work sessions!

Finally, thank you so much to my parents, Shari and Rob Conley. Mom, thank you especially for your runs to Colorado College to take pictures for me while I was in Virginia. And Dad, thanks for working with mom to get those pictures to me! I love you both, and I never would have been able to have such an amazing experience working on this project without you. 


\begin{abstract}
I begin by exploring the context, reception history, and scholarly conversation surrounding Helen Hunt Jackson’s 1884 novel Ramona. This historical commentary demonstrates the importance of studying the novel as part of the complex issues surrounding the $19^{\text {th }}$-century relationship between Native Americans, the United States government, and the American people_-among many other topics. As such a significant object of study, it is important to have a text of the novel that fulfills Jackson's final authorial intentions, for the text was corrupted in its transmission from Jackson's manuscript, to its serialization in the Christian Union, and to its publication in book form by Roberts Brothers. I collate the documents that Jackson was able to see and revise during her lifetime in order to reconstruct these lost intentions. In the textual commentary, I explain my editorial philosophies and guidelines. I ultimately present two chapters of the novel that I have edited according to these standards, as well as a record of all the changes that I made to the novel. The appendices give a list of the editions of Ramona that I examined for the project, as well as an overview of its publication history from 1884 until the present day.
\end{abstract}




\section{Introduction to the Critical Edition}

\section{Historical Commentary}

Summary of Ramona

Helen Hunt Jackson's 1884 novel Ramona is the extraordinarily popular love story of the half-Indian Ramona and the Temecula Indian Alessandro. The mystery of Ramona's parentage and the problem of how to award her inheritance is the impetus of the plot, lending a subtle gothic flavor to the storyline. Over the course of the novel, we discover that Ramona was born to a Scottish man, Angus Phail, and an Indian woman who remains unnamed. Her father brings her to his lost love, Ramona Ortegna, whom the child was named after. He begs her to care for his child and leaves little Ramona all that is left of his once vast riches. He vanishes and no one ever hears from him again. The elder Ramona passes away soon after, forcing her sister, the Señora Moreno, to take in the child, whom the Señora dislikes because of her aversion to Ramona's miscegenation.

The novel begins with a then-typical event on a Mexican Ranch, a sheep-shearing, for which the Señora hired a band of Indians, led by Alessandro. Alessandro falls instantly in love with Ramona, who gradually falls for him in turn, and they pledge themselves to be married. The Señora forbids their union and shows Ramona the jewels that her father has left her, threatening to keep them if she marries Alessandro. Alessandro, who had gone back to his home to let the clouds blow over, returns in despair, saying that the Temecula people have not only been forced out of their homes, 
but that many of them were murdered by white settlers and had their money and assets stolen. Ramona goes with him to be married anyway, though he is destitute and the Señora disowns her for doing so. They are married by a soldier-like Franciscan priest named Father Gaspara and begin their lives in poverty and marginalization.

After they manage to establish a home at last and have a child, the child gets sick and dies because the doctor at the government Indian Agency refuses to go and treat her. This event makes Alessandro go mad, and he accidentally takes a white man's horse, leaving his own horse in its place. The white man is furious, and murders Alessandro. Ramona, alone and impoverished with her second child, who is also named Ramona, is eventually rescued by Felipe and marries him. He gives her the jewels her father left her, which she in turn asks to be kept safe for her child. Finally, they leave the country for Mexico, with the air of going from hell into paradise.

Ramona in Context of Jackson's Evolving Strategies for Indian Reform

Ramona was a culmination of Jackson's previous literary efforts on behalf of the Native Americans, and turned out to be the last of the many literary weapons that she deployed in her war to secure just treatment for them. Her passion for "the Indian Question" caught fire late in her life and successful literary career. In 1879, when she was 49 years old, she heard Standing Bear speak in Boston about the horrors the Ponca tribe had endured because of the United States government's incompetent and cruel treatment. Their land and assets had been stolen; in their forced relocation to a reservation, they starved and died; and the land that they were supposed to live on could not be cultivated 
and did not support enough game to live on. ${ }^{1}$ Furious, Jackson decided from then on to focus all of her power on alleviating the suffering of Native Americans at the hands of white people.

She was relentless. From 1879 until 1885, when one project failed to garner the reactions she wanted, she simply began another. The different strategies she uses for these projects are interconnected, and what she learns from one piece she uses in the subsequent ones. Her writings on behalf of the Native Americans, then, cannot truly be considered separate; she builds on each of her previous works, reusing old tactics by framing them within new ones, in the hopes of finding the literary method and genre that would prove the catalyst to a massive movement.

She began her battle by writing furious letters and articles, employing her intricate network with the most powerful people in publishing. She mobilized for her first largescale attack on the American reading consciousness by meticulously doing research at the New York Astor Library. She believed that exposing the hard, bare facts of mistreatment of Native Americans throughout history would be the most effective way to persuade her readers to her cause. Her treatise A Century of Dishonor was published in 1881 by Harper and Brothers. With it, she meant to assail Congress from two fronts: she hoped readers of her book would pressure Congress for changes, and that Congress members, reading the book themselves, would be inspired on their own to take action. To this end, she paid to have a copy of the book sent to every member of Congress. ${ }^{2}$

\footnotetext{
${ }^{1}$ Phillips, Kate. Helen Hunt Jackson: A Literary Life. (Berkeley: University of California Press, 2003), 223. Phillips's biography examines Jackson's life according to her various genres of work and incorporates literary criticism.

${ }^{2}$ Phillips, Literary Life, 235.
} 
When the tough facts of history failed to guilt Congress into action, she was disappointed and disheartened, but readily changed tactics. Next, she combined hard fact with regionalism, and focused on a specific group of Native Americans as a case study: the Southern California Mission Indians, that is, the Native Americans who had been attached to and converted in the Franciscan Missions. In 1881, she journeyed to Southern California and wrote travel essays for Harper's and the Century Magazine that searched "out traditional ways of life amid the changes being wrought by the spread of American industrialization." ${ }^{3}$ These essays were the beginning of her understanding of this region, the one that would become the setting for Ramona.

Inspired by her visits to Southern California, she decided to become directly involved with the government. She managed an appointment as a special government agent to go and write a report on the condition of the Native Americans in California's southernmost counties. She would make recommendations on how to manage their land: whether the government should set land aside, or purchase more land to be made into reservations. She travelled to Southern California once again in order to gain eyewitness evidence along with a fellow agent, Abott Kinney, but ended up writing the report mostly on her own. She titled it the Report on the Condition and Needs of the Mission Indians of California. Unfortunately, even her government report did not inspire much change for the Native Americans. ${ }^{4}$

She did not waste what she learned in California. If history, reports, facts, and regional articles did not move the public and the government, perhaps a novel would. Novels had effected great social change in the past-Harriet Beecher Stowe's Uncle

\footnotetext{
${ }^{3}$ Phillips, Literary Life, 237.

${ }^{4}$ Phillips, Literary Life, 247.
} 
Tom's Cabin had given the movement for abolition enormous power. Her idea to use a novel to convey her message was inspired by her theory that "people will read a novel when they will not read serious books." 5 She implies that she meant to build on the small audience that $A$ Century of Dishonor found, versus giving the treatise up as a failure. In October of 1883 she suddenly received the inspiration for Ramona and wrote it more quickly than she had ever written anything before.

Her strategy for the novel was built on the tactics she used in A Century of Dishonor and her Southern California essays. She meant to use the case study of the Mission Indians and the Southern California region to focus the nation's attention on the United States government's appalling treatment of Native Americans overall, both throughout history and in her present day. While she did not employ bare facts, she writes in a letter to Thomas Bailey Aldrich, editor of the Atlantic Monthly, that "every incident in Ramona, (ie. Of the Ind. Hist) is true." "It is quite possible that Jackson hoped that readers would be inspired by the truth of her novel to seek out the facts given in her 1881 treatise.

In other words, she kept the factual and regional tactics of her previous work, but veiled them in a fictional plot and made them more appealing by portraying them through a sentimental mode of writing. She retained her perhaps naïve belief that if enough people were moved to demand help for the Native Americans from Congress, lawmakers would have to listen. Although the novel did enormously well, Jackson was, once again,

\footnotetext{
${ }^{5}$ Jackson, Helen Hunt. The Indian Reform Letters of Helen Hunt Jackson, 1879-1885. Valerie Sherer Mathes, ed. (Norman: University of Oklahoma Press, 1998), 337. This book is an essential resource to studies of Jackson's efforts for the Native Americans. It is currently the only book of Jackson's letters, which are difficult to gain access to because they are scattered all over the country, in often obscure locations. Her bibliography gives a helpful list of many of these locations.

${ }^{6}$ Jackson, Letters, 337.
} 
disappointed. Readers loved it for its story, rather than for its commitment to inspiring justice for Native Americans.

She decided that her next main project would be to appeal to an entirely different audience: children. She believed that a child's impression of Native Americans was one of fear and ignorance, attitudes that traveled with them into adulthood. She more than likely came to this conclusion because of her own views as a child: she writes in a letter to Charles Dudley Warner, an American novelist and magazine editor, on October 2, 1884 that "I grew up with my sole idea of the Indian derived from the accounts of Massacres. It was one of my childish terrors that Indians would come in the night, \& kill us!"7

In fact, she had just written a children's book that had as one of its themes the mistreatment of Native Americans. In the same year that she released Ramona, 1884, she published The Hunter Cats of Connorloa, which featured its main characters, orphans Jusy and Rea, learning about the new country that was to be their home- the United States. They were told that white settlers were treating Indians badly and forcing them out of their homes, when all they wanted to do was live in peace. ${ }^{8}$ The passage clearly takes its inspiration from the fate of the Temecula Indians in Ramona.

The book's main character was based on her fellow government agent Abbot Kinney: in a letter to him, she says "I have ordered a copy of the Hunter Cats of Connorloa sent to you. You will laugh to see yourself saddled with an orphan niece and nephew." ${ }^{\text {9 }}$ It seems probable that Jackson was inspired by this particular project to devote a story entirely to this theme, to be published in the magazine the Youth's Companion. However, she was never able to

\footnotetext{
${ }^{7}$ Jackson, Letters, 330.

${ }^{8}$ Jackson, Helen. The Hunter Cats of Connorloa. (Boston: Roberts Brothers, 1884).

${ }^{9}$ Jackson, Letters, 328.
} 
write it, or to find the key to winning American hearts to her beloved cause on a large scale. Compounded with a badly broken leg, she contracted stomach cancer, and was unable to fight her way out of the illness. She died on August 8. 1885.

Publishing Ramona

Publishing in periodicals was the bread and butter of Jackson's career, and she was incredibly well-connected with literary and publishing professionals. Indeed, she did not publish her first novel until 1876-when she was 46 years old — but rather preferred until then to bring together her pieces published in periodicals into compilations. She made very little from her published books, but demanded, and received, high paychecks from periodicals for her articles dealing with domestic advice and travel, as well as her short stories and poems. In general it was usual for American authors to make their reputations in periodicals and to find more readers through magazines, than through selling their published books. ${ }^{10}$

Because of her strong background in periodicals, it is surprising that Ramona was Jackson's only serialized novel. She decided to have it serialized in the Christian Union with the hope that it would become as visible to as many people as possible. She explains her motives for selecting this periodical in particular in a letter to Amelia Stone Quinton on April $2^{\text {nd }}, 1884$ - one month before Ramona appeared:

The paper has paid me (for them!) — a large price for the story — a good deal less than half what I should have for it in the Mags, — however — but I preferred this $-1^{\text {st }}$ because the Mags. Could not begin it for a year \& a half $2 \mathrm{~d}$ to hit the religious element $-3^{\text {rd }}$ to have only a weeks interval between the

\footnotetext{
${ }^{10}$ Phillips, Literary Life, 111
} 
numbers. - I believe 100,000 readers of this sort will do more for the cause, than four times that number of idle magazine readers. ${ }^{11}$

She had chosen a very successful magazine for her novel. The Christian Union was originally a Baptist periodical that was started in 1867 and was named the Church Union. In 1869, it was sold to J. B. Ford and Company, which made it into a nondenominational family periodical and renamed it the Christian Union. It was a large quarto of 16 pages, and then later of 24 pages, was not particularly well printed, and had a poor quality paper. But, it was very affordable, at a subscription costing just $\$ 3.00$ a year. The periodical had many distinguished authors who regularly contributed to it, including Louisa May Alcott, who like Jackson was regularly published by Roberts Brothers, and Harriet Beecher Stowe, the author of Uncle Tom's Cabin, one of Jackson's professed most important models for Ramona. ${ }^{12}$

Jackson knew the magazine well, for she had begun contributing to it in 1873. She began doing so because an editor whom she had a strong relationship with from the periodical that she published in the most, the New York Independent, Oliver Johnson, moved there in that year. ${ }^{13}$ The periodical was highly successful, though Frank Luther Mott points out that circulation numbers are difficult to pin down with any accuracy for $19^{\text {th }}$-century periodicals because publishers preferred to keep them secret. However, the 1870 's seems to have been a profitable time for the magazine and was the only religious periodical in the country to reach a reported circulation of 100,000. Although the Christian Union lost many readers after being rocked by a scandal concerning its editor in chief, it maintained a circulation of 20,000 and was still well respected. Ramona was

\footnotetext{
11 Jackson, Letters, 319.

${ }^{12}$ Mott, History, 3: 423

${ }^{13}$ Phillips, Literary Life, 110
} 
its greatest hit of the decade. ${ }^{14}$ It appeared from May 15 through November 6, 1884 and met with great success and high popularity, exactly as Jackson had intended.

Roberts Brothers, which published the first edition of Ramona in book form, was a small publishing firm that worked out of Boston. Though it was owned in part by Lewis Roberts, Thomas Niles truly ran the firm and made it what it was; when he died, the firm essentially died with him and was sold to Little, Brown and Company in 1898. At a time that publishers were condescending to female authors, Niles was known in particular for being friendly to them and supportive of their work. Raymond L. Kilgour, in his book on the history of the firm, explains that Niles, "whatever difficulties his shyness may have caused him, was sympathetic with women's interests and intellectual yearnings and was regarded as a friend by his authors". ${ }^{15}$ Niles published Louisa May Alcott, Sarah Woolsey, and Jean Ingelow, in addition to many others.

He had a good relationship with Jackson. She had published her first books, Verses and Bits of Travel, with Fields, Osgood and Co., but she had to pay for the plates herself. She changed to Roberts Brothers for her next book, probably getting their name from her friend Sarah Woolsey (who would later give her encouragement for Ramona). ${ }^{16}$ She published Bits of Talk about Home Matters with Niles in 1873, which was another compilation of essays she had published in periodicals.

Once it had been written, serialized, and type set, Ramona was printed at the Cambridge University Press, which was owned by John Wilson and his son-their names appear on the copyright page and on the last page of chapter 26 in the novel. The press

\footnotetext{
${ }^{14}$ Mott, Frank Luther. A History of American Magazines, 1741-1930. (Cambridge: The Belknap Press of Harvard University Press, 1958), Vol. 3: 423-427.

${ }^{15}$ Kilgour, Raymond L. Messrs. Roberts Brothers Publishers. (Ann Arbor: University of Michigan Press, 1952), 40.

${ }^{16}$ Kilgour, Roberts Brothers, 40, 125.
} 
did all of the printing for Roberts Brothers. The paper they used came from Tileston and Hollingsworth and was stored at the press itself. The books were then bound at the Riverside Bindery, which also stored them until it was time to ship them. ${ }^{17}$ The Bindery was also located in Cambridge and was founded by Charles Little, one of the partners of Little, Brown and Company.

Ramona's publishing history from the moment it appeared in book form in November of 1884 until its latest publishing in 2013 is incomplete, partly because of the destruction of the Roberts Brothers records in the 1930's, but mostly because there are so many printings of Ramona that it would be a gargantuan, and probably impossible, task to gain a complete picture of it. The only known number of its printings, and the most cited, comes from Ruth Odell's biography of Jackson. She explains that "if the test of a novel be, as is often stated as axiomatic, that it live, then Ramona may claim through its more than three hundred printings... to being an American classic". ${ }^{18}$ We have to take Odell's word on the three hundred printings - hers is the only statement on this aspect of the publication history that I was able to discover.

The novel's early history is the best documented. Kilgour explains that Thomas Niles, Jackson's editor at Roberts Brothers, believed in the novel from the first, giving it a large printing of 3,000 copies. Jackson, who was always insistent on being paid well for work, was advanced 1,000 dollars. ${ }^{19}$ It sold a thousand copies in its first month. Advertisements at the backs of the first editions give clues to the numbers printed and sold: by the end of 188522,000 copies were sold, by 1889, 65,000 were sold, and in 1893 100,000 copies of the book had been purchased. Overall, the novel was a steady seller,

\footnotetext{
${ }^{17}$ Kilgour, Roberts Brothers, 261.

${ }^{18}$ Odell, Helen Hunt Jackson, 226.

${ }^{19}$ Kilgour, Roberts Brothers, 259.
} 
versus being a best seller, especially in its first 60 years, with it being most popular in Southern California (the Los Angeles Library by itself bought a thousand copies). ${ }^{20}$

\section{Ramona's Troubled Reception}

Ramona is unique of Jackson's other writings for her cause in that it was wildly popular and had a large-scale effect. The fascinating trouble that it presents is that its popularity stems from all the wrong reasons. It was beloved by contemporary audiences, even through audiences to the present day, for its romance, realistic description of California scenery, and pastoral nostalgia — not for its passionate cry for justice.

Jackson's perception of whether the novel's message had gotten through shifted during the short period of its reception that she was able to witness - she died not quite a year after Ramona's publication. At first, she was hopeful that her missive had penetrated the country's hostile attitude towards Native Americans. She formed this optimism while watching reactions to the novel's serialization, which came before its distribution in book form. She wrote in an October letter to Warner that "It is winning good praise, I think \& I hope it will stir people up--...,21

She continued to meticulously read reviews, and analyze them throughout her correspondence, after the novel's publication in book form in November 1884. This analysis reversed her first impression that the novel's reception was headed in the right direction. Although the reviews lauded her novel, she was disappointed in the reasons that reviewers gave for its excellence. In December 1884 she dispiritedly writes to

\footnotetext{
${ }^{20}$ Hart, James D. The Popular Book: A History of America's Literary Taste. (New York: Oxford University Press, 1950), 203.

${ }^{21}$ Jackson, Letters, 330.
} 
Warner: "I am sick of hearing that the flight of Alessandro \& Ramona is an "exquisite idyll", \& not even an allusion to the ejectment of the Temecula band from their homes.",22 In the end, though she seems ambivalent about whether her book had after all inspired some action for the Indians, she focuses her hopes on the book's futurity. She writes to her husband in March 1885, "It Ramona \& the Cent. of Dishonor have not helped—one more would have made little odds—But they will tell in the long run—,"23

The answer to how audiences could have missed Jackson's message, or if they did not miss it could have ignored it, is complex and even still offers rich ground for scholarly inquiry. Jackson herself guesses why the novel failed in its intended effect in a January 1885 letter: "I fear the story has been too interesting, as a story--: so few of the critics seem to have been impressed by anything in it, so much as by its literary excellence, etc. etc.--" ${ }^{24}$ Ironically, Jackson in fact set out in the first place to write as engaging a "story" as she possibly could. The trouble was that the reading public became so immersed in the plot that they did not want to leave it; they did not want to translate their reading experience into the real world.

Jackson's agenda for Ramona was in this respect quite subversive; she wanted to lure readers into the story in order to get under their guard. She writes, "there is so much Mexican life in it, that I hope to get people so interested in it, before they suspect anything Indian, that they will keep on.--" 25 Asking why she thought her story needed to be subversive leads, for one thing, to an illumination of Jackson's conception of her targeted audience's identity. The problem that Jackson fought to resolve was the

\footnotetext{
${ }^{22}$ Jackson, Letters, 338.

${ }^{23}$ Jackson, Letters, 345.

${ }^{24}$ Jackson, Letters, 341.

${ }^{25}$ Jackson, Letters, 307.
} 
disconnection between the desires of the nation, of her reading public, and anything to do with Native Americans. In other words, she evidently did not think that people associated them with pleasure or entertainment, or indeed with any positive form of desire at allNative Americans were not "interesting" in a way that engaged a reader's want to read a book through. If there was no desire connected to Native Americans in the first place, Jackson's message would not only pass unheeded, but unread.

Readers desiring to avoid Native Americans would not even pick the novel up in the first place, if they connected the title with the Indian Question. Jackson changed her original title, which she was very proud of, because she was afraid it would alienate her readers. She writes to Aldrich that the story is "not to be called after, "In the Name of the Law," but "Ramona." - I grudge giving up the other title: but I am advised strongly that it will be a mistake; - will "show my hand". ${ }^{26}$ Perhaps if she did title the book "In the Name of the Law," it would have created a much different stir. But, probably concluding that the relative failures of her previous works came from their subject matter more than any other factor, Jackson did not want readers to know that there was a game afoot until it was too late.

Jackson's character Aunt Ri, who ends up as a mother-figure to Ramona, symbolizes the attitudes that Jackson perceived in her public. When Aunt Ri first meets Ramona in chapter 22, allowing Ramona's family to take shelter in her tent from a raging snowstorm, she does not think well of Indians. She cries: "Hev we reelly took in Injuns? What on airth — Well, well, she's fond uv her baby's enny white woman! I kind see teht; an', Injun or no Injun, they've go to stay naow. Yer couldn't turn a dog out'n sech

\footnotetext{
${ }^{26}$ Jackson, Letters, 318.
} 
weather's this". ${ }^{27}$ In Aunt Ri's conception of racial hierarchy, Indians were only just above animals. They were far below white people, if they could not even form an attachment to their children; only when Aunt Ri actually sees Ramona's affection for her child is she able to revise that opinion.

At the end of the novel, in chapter 26, the narrator explains that during Aunt Ri's stay with the Cahuilla people, "the last vestige of her prejudice against Indians had melted and gone". ${ }^{28}$ Empirical experience is the instrument of Aunt Ri's transformation. Only when she meets actual Native Americans and spends time among them is she able to value them. She says of her experience with the Cahuillas, "I jest wish the hull world could see what I've seen! Thet's all!"29 Indeed, Jackson emphasizes Aunt Ri's keen sight when she is first introduced: the narrator explains, "her pale blue eyes were still keensighted". 30

This theme permeates Jackson's correspondence as well. She repeats the refrain that if only people could see for themselves the misery of the Indians, they would work to help them. For instance, she writes in an 1883 letter to Henry Teller, the Secretary of the Interior from 1882 until 1885, of her quest to help save the land of the Saboba Indians, "I know if you could see the village, you would say, "it shall be protected". ${ }^{31}$ Similarly, In an August 1884 letter to Henry Laurens Dawes she writes "I wish you could see the Rincon village — the best cultivated lands we found — ditches, corrals, horses, cattle - they are an industrious people". ${ }^{32}$ Ramona, therefore, after a reader's desires were engaged

\footnotetext{
27 Jackson, Helen. Ramona. (Boston: Roberts Brothers, 1886), 382.

${ }^{28}$ Jackson, Ramona, 470.

${ }^{29}$ Jackson, Ramona, 471.

${ }^{30}$ Jackson, Ramona, 382.

31 Jackson, Letters, 269.

32 Jackson, Letters, 324.
} 
and sustained by the Mexican aspects of the novel, was meant to be as good a substitute for empirical experience that Jackson could create for her readers. Once they saw for themselves the character of the people they held prejudices against, those attitudes would melt away, even as Aunt Ri’s did.

Exactly how Jackson's intention to use these subversive and empirical methods to create an Aunt Ri-like transformation in her readers' attitudes is the concern that most often frames critical discourse surrounding the novel. In recent scholarly conversation, three main points have emerged as the focus of theories that work to explain this phenomenon: Ramona's character, the focus on the California landscape, and the novel's elegiac, nostalgic tone, especially as it relates to the its sentimental mode.

To look at some case studies of these theories, Dydia DeLyser posits that the book's message failed because the Native Americans have no futurity in the novel, and because Ramona never fully becomes a Native American - she is ethereal, above the rest of the characters. ${ }^{33}$ Jackson's biographer Kate Phillips similarly stresses Ramona’s lack of connection to Native American culture, remarking that Ramona and Alessandro are both "whitewashed," that they are too similar to their readers to truly represent the culture that Jackson wanted them to. In other words, though readers could connect to Ramona herself, they could not link her with Native American culture. Robert McKee Irwin points out a different difficulty readers could have in understanding Ramona in a Native American context, saying that "she is not a simple character to interpret in any framework of racial

\footnotetext{
${ }^{33}$ DeLyser, Dydia. Ramona Memories. (Minneapolis: University of Minnesota Press, 2005), 27. DeLyser's book Ramona Memories is a fascinating investigation that seeks to answer why Ramona inspired a thriving tourist industry in Southern California. Her book examines the practices of tourists at Ramona landmarks, the development of attractions, and the impact of the novel on social memory.
} 
or national allegory". ${ }^{34}$ It would not be easy to understand Ramona in a strict context of raising awareness and indignation about the Indian situation because of her Mexican upbringing and Scottish heritage.

Linked to the issue of Ramona's disconnection from Native American culture is the fact that the landscape is racialized as a Mexican space, and as a nostalgic Mexican space at that. DeLyser explains that the rise in travel accessible to the middle class allowed readers to concentrate on the novel's California landscape, over its social agenda, by going to visit it themselves. This was a powerful force in the reception of the novel and led to the creation of a massive tourist industry surrounding it in Southern California. Irwin also cites the issue of the novel's nostalgic setting, "which yearned for idyllically peaceful past of Spanish colonial mission culture" versus focusing heavily on contemporary Indian spaces. The result was that readers could focus on the Mexican aspects of the novel, instead of having their affections transferred from the Mexicans to the Native Americans. Phillips agrees, explaining that "Jackson seems to be describing events buried solidly in the past rather than ongoing travesties that demand present intervention. ${ }^{״ 35}$ She explains that Jackson implies that, because the novel's events seem to have happened so far in the past, the Native Americans, in the contemporary day, looked as though they were far past saving.

No doubt there is no one true reason as to why the novel had the effect that it did, but this multiplicity only makes the study of its reception more worthwhile. It leads to explorations of the deep contradictions that $19^{\text {th }}$-century American law was embroiled in

\footnotetext{
${ }^{34}$ Irwin, Robert McKee. "Ramona and Post Nationalist American Studies: On 'Our America' and the Mexican Borderlands". American Quarterly. 55.4 (December 2003): 539-567. McKee's focus is to push against Jose Marti's adoption of Ramona as a Latin American novel and calls for American Studies to analyze the Mexican Borderlands when forming theories concerning intercultural race.

${ }^{35}$ Phillips, Literary Life, 261.
} 
concerning the Native Americans. It is fertile ground for exploration of American imperialism, examinations of how the multiple colonizations of the land clashed together, the confusion surrounding the definition of race, and the prejudice and anxieties that enveloped miscegenation.

\section{Textual Commentary}

\section{Rationale for a New Edition}

This rich ground for scholars emphasizes the need for the existence of a reliable text of the novel. For, although just about every imaginable kind of edition exists already, none of them has focused on whether or not Jackson's authorial intentions have been fulfilled. If, and how, the text changed during its transmission from the manuscript, to the Christian Union, to proof stages, and then to the first edition - and if Jackson approved of these changes - is a subject needing exploration.

Indeed, only two existing editions carry a textual note, which gives a brief rationale for where the text of their particular edition is taken from, and why: the 2005 Modern Library Paperback Classic, and the 2008 Broadview Press edition. The rest of the editions are silent on matters of textual transmission, authorial intention, and if the text of the novel they have produced is accurate, according to Jackson's wishes.

The 2005 comes the closest to Jackson's intentions for her text:

The text of this Modern Library Paperback Classic of Ramona by Helen Hunt Jackson follows the first edition of Ramona: A Story by Helen Jackson (H. H.) 
(Boston: Roberts Brothers, 1884). Several obvious typographical errors have been silently corrected. ${ }^{36}$

The 1884 first edition is a choice made with this piece of good reasoning: it is the closest in time to Jackson's proofs. The problem remains, though, of not confirming that the editorial choices Roberts Brothers made in 1884 were sanctioned by Jackson.

Furthermore, the reader cannot know which "silent" emendations the editor has made to the text, and how these emendations might have deviated from Jackson's intentions.

The 2008 textual note also has problematic editorial methods:

This edition used here is the 1912 reprint by Little, Brown and Company. From the first edition by Roberts Brothers in 1884 to the Signet Classic (Penguin) edition of 2002, the text of the novel has been quite consistent. Here, the most glaring misspellings, typos, or punctuation errors have been silently corrected; however, most of Jackson's idiosyncratic hyphenations or inconsistencies in spelling have been retained. ${ }^{37}$

The first problem is its use of the 1912 Little, Brown and Company as its copy-text. Although type damage shows that the 1912 was printed from the first edition plates, it contains flaws that were not present in the first issues of the novel. Twenty-eight years after they were first created, the first edition plates were quite damaged, with pieces broken off. For example, the first sentence of the first chapter is supposed to begin: "It was sheep shearing time in Southern California;" In the 1912, the semicolon, being at the end of the line, has broken off, leaving no punctuation mark at all. The 2008 edition solves this problem by silently putting a comma after California, which, as an examination of the manuscript and first editions reveals, is not what Jackson wanted.

The next assertion the note makes is true, that the text has remained relatively stable over its long publication history--excepting some accidentals and compositor errors, as

\footnotetext{
${ }^{36}$ Textual Note in Ramona. New York: the Random House Publishing Group, 2005.

${ }^{37}$ Senier, Siobhan. "A Note on the Text" in Ramona. (Buffalo: Broadview Press, 2008), 34.
} 
well as the problems in the 1912 edition. However, what constitutes an "error" in the text, or how it is established that something is an error, is not explained. How does the editor know, for instance, that a "misspelling" was not the spelling regularly used by Jackson? In this vein, how does the editor know that the hyphenations and spelling inconsistencies were Jackson's? For instance, the manuscript reveals that the hyphenations in the first edition were not Jackson's at all; the Christian Union and Roberts Brothers added in most of them. Lastly, the principle of silently correcting "errors" does not give the reader an understanding of what has been corrected and why, nor does it give a picture of how the text has been transmitted.

I only single out these editions because they have explanations of their editorial methods, and because those textual notes demonstrate the need for more thorough work to be done in establishing a reliable text. These editions are useful in other ways besides understanding the text's transmission and the author's intentions- - their goals are not to discover and fulfill Jackson's intentions for what her text was, but to give historical contexts of and modern perspectives concerning the novel. Each edition of Ramona represents a unique historic moment in and of itself and would be valuable for that reason alone.

I seek to create a different kind of edition. My critical edition examines the transmission of the text from Jackson's hand to the Roberts Brothers first edition, in order to determine if the Roberts Brothers' editorial decisions were in fact authorized by Jackson. It renders visible the variants between the versions of the text that Jackson would have been able to see in her lifetime. I give a record of every editorial decision I 
made in order to explain why I have chosen to keep each variant in the text, and ultimately strive to build a text that best reflects Jackson's intentions for her novel.

Editorial Methods Used in Building this Text

In order to uncover the variants in the documents that Jackson would have been able to see, and perhaps revise, I collated the manuscript, Christian Union, available proofs, and Roberts Brothers first edition with each other, recording the findings in an Excel spreadsheet. I collated the proofs with the first edition by sight. I transcribed the manuscript, used OCR to create digital files of the Christian Union and the first edition, and collated them using JUXTA, a program developed originally by NINES, of the University of Virginia. I also compared the documents by sight, as a back up to the digital collation method.

Interpreting the variations once I had discovered them proved a challenging process because few details about Jackson's interaction with either the Christian Union or Roberts Brothers in preparing her text for publication have been preserved. How many proofs Jackson corrected and when she corrected them, what input her editor at Roberts Brothers, Thomas Niles, had into the manuscript, whether or not she was pleased with the changed punctuation that appeared in both the Christian Union and the first edition—all these factors are unknown. This lack of information is partly because Jackson, concerned with protecting her privacy, asked that all of her personal papers be burned upon her death. ${ }^{38}$ Additionally, both the correspondence between Jackson and Niles and any

\footnotetext{
${ }^{38}$ Odell, Helen Hunt Jackson, 219. She also requested that if a life of hers had to be written, it should be done by Hamilton Wright Mabie. He was assistant editor of the Christian Union in 1884 and would have worked closely with Jackson on Ramona. Clearly, then, Jackson had a good relationship with the magazine.
} 
records concerning Ramona's publication were lost when the Roberts Brothers archives were carelessly destroyed in the 1930's. ${ }^{39}$ In her surviving correspondence, she does not give many details about the editing and publication process of her novel. As a result of this scarcity of evidence, I needed to reconstruct the novel's proof and publication processes in order to build an edition that embodies her intentions for her text.

By saying I am "building” a text, I refer to G. Thomas Tanselle's essay "Editing Without a Copy-Text", in which he explains that the editorial process

remains one of building up a new text rather than making changes in an old one...the idea that a critical text emerges from active choices made among the variant readings (along with, of course, the editor's own interventions, when necessary) emphasizes editorial judgment. ${ }^{40}$

I take this perspective as the guiding philosophy of my editorial process. I do not use a copy-text, that is, I do not base my edition on one particular document, such as the manuscript. I do not assume that any one document is more "correct" than any other. Instead, I "build" my text from the blank page up. In other words, although I mostly use manuscript readings in my critical edition, I do not make a decision to include a reading in my edition without judging whether or not Jackson would have wanted it there, without weighing all possibilities equally. The text I build incorporates variations from the documents that Jackson would have been able to see and revise during her lifetime. In doing so, it aims to fulfill her final intentions for her text, that is, the latest revisions that she made to it, the latest form that she herself authorized.

\footnotetext{
${ }^{39}$ Kilgour, Roberts Brothers, 250

${ }^{40}$ Tanselle, G. Thomas. "Editing Without a Copy-Text." In Literature and Artifacts. (Charlottesville: The Bibliographical Society of the University of Virginia, 1998), 254. An important essay that explores the scholarly debate over the use of a copy-text, the need for critical editions, and the place of editorial judgment in the creation of those editions.
} 
I based my judgment on what Jackson would have intended for her text on research concerning her revision habits in general, the revision habits she demonstrated in the manuscript of Ramona itself, and the patterns I uncovered in how Ramona was edited for both the Christian Union and the Roberts Brothers first edition.

\section{Jackson's Revision Process}

Jackson would have cared deeply about having her work printed exactly as she would have wanted it to. Phillips explains that she learned much of her meticulous writing style from her mentor Colonel Higginson. He advised young writers to avoid unessential emphasis in punctuation such as exclamation points, underlining, and italics, allowing a sentence to emphasize itself. Philips explains that at the beginning of her career, "in the matters of sentence emphasis and organization...her narrative prose demonstrates an increasing sophistication," and later, in the 1870's when she was more established, that "her commitment to exacting word choice is evident in her correspondence with editors where she sometimes argues over the use of particular words or expresses dismay when blunders are committed in her work." ${ }^{41}$

Jackson wrote Ramona at an unusually fast pace, compared to her other novels. This pace, though, did not mean that she was sloppy in her manuscript, or that she was not satisfied with her first instincts. She writes in a letter on February 5, 1884,

Now you will ask what sort of English it is I write at this lightning speed. So far as I can tell, the best I ever wrote! I have read it aloud as I have gone on, to one friend, of keep literary perceptions and judgment...she says it is smoothstrong-clear. ${ }^{42}$

\footnotetext{
${ }^{41}$ Phillips, Literary Life, 99-100

${ }^{42}$ Jackson, Letters, 314.
} 
This remark strengthens the validity of her manuscript as a source of her final intentions. Her manuscript does show changes, but on the whole Jackson seemed satisfied with her first draft. As she wrote, she tended to be more certain about her word choice than her sentence structures. Most of her revisions, which she made as she wrote the manuscript, do not change the words in the sentence, but rather their order; words she cancels in one part of a sentence she will use in a later part. She made few overall revisions when she went back over the manuscript to make corrections, after she had finished writing it. These separate revisions are apparent because of their darker ink.

Throughout writing and then correcting the manuscript, it seems that she was less careful about editing for punctuation, than for making sure that her word choice and sentence structure was perfect. Often, when she revised her word choice, she would not revise the punctuation to go along with it, leaving instead the punctuation from her rejected sentence structure. ${ }^{43}$ Occasionally, she misses the fact that she's left out a punctuation mark altogether. There is no sure way to know what punctuation mark she intended in these cases. I have guessed that she would have caught them in her proof stage, and that Christian Union and Roberts Brothers, especially when they both have the same punctuation mark in the same place, reflect her proof corrections in their readings.

For in all likelihood, she corrected proofs of the novel for its serialization in the Christian Union. It was her usual habit to carefully correct proofs for all of her work, not just her novels. Phillips explains that "she often further revised her published periodical

\footnotetext{
${ }^{43}$ Most of the manuscript of Ramona is housed in Tutt Library, at Colorado College in Colorado Springs. The first page of chapter 16 is in Amherst at the Jones library, much of chapters 10 through 14 are at the Lilly Library of Indiana University at Bloomington, and twenty pages are missing altogether (Phillips).
} 
work before reprinting it in book form." ${ }^{\text {44 }}$ Jackson did correct proofs for Roberts

Brothers, proofs that I was able to examine. ${ }^{45}$ They have very few corrections, and only one that is clearly in Jackson's hand: a sentence that was added to chapter four. The rest point out mistakes in the type setting, misspelled words or a period in the middle of a sentence, for instance, and have, in another person's handwriting, a note along the lines of, "this was made right before printing."

The reason that I posit she corrected proofs for the Christian Union, with much more extensive revision than that she did for Roberts Brothers, is that the magazine and the first edition have mostly the same text. Between the magazine and first edition, there are only a few punctuation differences, which I attribute both to different house styles and lack of care on the Christian Union's part. For instance, the periodical omits some Spanish accents and hyphenations. Mott reinforces this probability, explaining that the magazine tended in general to be a little careless with printing its copy accurately. ${ }^{46}$ The few word choice differences it has with the first editions are likely due to the same cause. As for word changes that both the Christian Union and the first edition have, as different from the manuscript, it is likely that Jackson herself was the author of these changes in a proof stage. These changes are characteristic of the revision style Jackson shows in the manuscript itself. Here, edits of sentence structure appear, as well as some cancellations of minor words - the same kinds of changes are made from the manuscript in the periodical and first edition.

Since the Roberts Brothers first edition is so similar to the Christian Union serialization, it is likely that Roberts Brothers had either the serialization itself on hand

\footnotetext{
${ }^{44}$ Phillips, Literary Life, 100.

${ }^{45}$ These proofs are available for examination in the Tutt Library at Colorado College, Colorado Springs.

${ }^{46}$ The digitization of the weekly Christian Union chapters of Ramona is available online through ProQuest.
} 
while they typeset Ramona, or the proofs containing both Jackson's revisions as well as those made by the magazine. In all, though, what exactly the relationship was between the Christian Union and Roberts Brothers, and how it was that their documents ended up being so similar, can only be posited at through reconstruction and educated guessing.

In summary, it seems that this chronology is likely to have been Ramona's journey into print:

1. Jackson wrote the manuscript from December $1^{\text {st }}, 1883$ until March $1^{\text {st }}, 1884$, making revisions along the way.

2. She went back over the manuscript and made a few minor revisions.

3. She corrected proofs for the Christian Union between March $1^{\text {st }}$ and May $15^{\text {th }}$, 1884.

4. Ramona ran each week in the Christian Union from May $15^{\text {th }}, 1884$ until November $6^{\text {th }}, 1884$.

5. Roberts Brothers set type for the novel probably using the proofs Jackson corrected for the magazine.

6. Roberts Brothers sent Jackson proofs, with minor corrections of typos markedJackson adds a sentence to chapter four that does not appear in the first edition.

7. The published first edition came out in later November, after the serialization finished.

\section{Editorial Guidelines Concerning Substantives and Accidentals}

The manuscript, the probable proofs that she corrected before the serialization, the Ramona that appeared in the Christian Union, the proofs given to her by Roberts Brothers, and the Roberts Brothers first edition were all the manifestations of her novel that Jackson was able to see, and therefore to make changes to. Her final intentions would be found in these documents. In my examinations of the stages that Ramona went 
through, I have determined that the Roberts Brothers first edition is not the best representation of Jackson's intentions. It does contain her first proof edits, and so is a mostly good representation for her word choices, excepting the sentence Jackson added to chapter four that was never put in. However, it also has a large amount of changed punctuation from the manuscript. It is entirely possible that Jackson changed some of it herself. However, because she tended to make few punctuation revisions in her manuscript, and because a lot of the punctuation changes in the first edition are clearly made for reasons of regularizing grammar, or made to have the book conform to house style, I have tended to trust the manuscript's punctuation as being more valid.

These are the punctuation patterns of Jackson's, which appear in the manuscript, that I have found are most often disrupted by the Christian Union and Roberts Brothers:

- Using a comma to separate two descriptors, or a list of two things (for example, the Señora being "imperious, and brimful of storm")

- Sometimes separating a list of three adjectives with commas, but often intentionally not doing so (for example: soft dark eyes)

- Using semicolons before coordinating conjunctions like "and", "but"

- Using a comma to set off dialogue

- Not using commas to set off dependent clauses at the beginning or ending of sentences

- Not using commas to enclose interruptive clauses

- The tendency to use "which" the same way as "that", without a comma in front of "which"

- Not using the serial/oxford comma

There are a few patterns that I judge Jackson would have expected an editor to clean up. I recognize that it is dangerous to say that Jackson would have wanted these 
corrections by another's hand to be part of her intended work, for, as Tanselle has pointed out, intention is not the same as expectation. I have marked each change that I made in these respects, though, so if readers do not agree that she would have intended such changes to be made, they will be at least able to see where I have put them in. I have used the Roberts Brothers corrections in these instances:

- Putting in apostrophes for possessive cases (For example, "Felipe's breeches")

- Many apostrophes in dialect sections marking missing letters are missing ( for example, apostrophes marking the letter ' $\mathrm{g}$ ': killin')

- Most likely on her use of Spanish ${ }^{47}$

A special punctuation difficulty is how Jackson would have intended the placement of certain comma dashes (,-). Jackson hardly uses comma dashes in the manuscript, but many of these punctuation constructions appear in Roberts Brothers. Complicating matters, in most instances where Roberts Brothers has a comma dash, the Christian Union has an em dash. This is such a pervasive pattern that it requires special attention; did Jackson intend the comma dash, the em dash, or the punctuation that she originally had in the manuscript?

Additionally, there is no one discernable pattern in which these comma dashes/em dashes are inserted. They are used as though they were commas, to set off commentary on the idea in the previous clause ("Like the wind galloped Benito,--Alessandro half lying on his back..."). They are used as though they were colons, with the clause before it

\footnotetext{
${ }^{47}$ Jackson does not seem overly familiar with the language, for example putting an accent over the $\mathrm{n}$ of "canon" and not of "Senora, Senor, Senorita". In the Hunter Cats of Connorloa, also published in 1884, Jackson displayed even more uncertainty in her use of Spanish, sometimes leaving out entire sentences supposed to be in Spanish for Roberts Brothers to fill in. Phillips explains that Jackson had to work through Spanish books slowly, relying on her knowledge of French and Latin (236). Humorously, in her introduction to the 2005 edition, Denise Chávez writes: "I do wish someone had corrected your Spanish" (Chavez Xv). Ironically, though, someone did correct it - but only to the extent of its spelling.
} 
giving a general idea, then the clause with the comma dash listing details or components of that general idea ("...the rest of the maids came running,--Anita and Maria, the twins,..."). They are used between repeated words, in order to show a change of direction (“An exceedingly clever woman for her day and generation was Senora Gonzaga Moreno,--as for that matter, exceedingly clever for any day..."). They are used to set off dialogue (She was resolved upon having Indians,--“God knows why...”). Finally, they are used to mark an interruptive clause in the middle of a sentence ("In the dim light of the one candle,-Father Gaspara allowed himself no luxuries,--the exquisite...").

Because these are general patterns, and because they are so varied, I have judged that they represent Jackson's corrections. I believe that she wrote in comma dashes, not the em dashes, for two reasons. First, she preferred complex dash constructions. Her correspondence is full of colon dashes, comma dashes, semicolon dashes, and period dashes. Additionally, her manuscript has several semicolon dashes, as well as some comma dashes. Second, in the case where Jackson has a comma dash, Roberts Brothers does as well—but the Christian Union has a simple em dash. Indeed, the Christian Union changes all of the Jackson's complex dash constructions. My theory, then, is that whenever Jackson wrote a comma dash into her proofs, the Christian Union, preferring simpler punctuation, omitted the comma in front of it. Therefore, whenever a comma dash appears in the first edition, I take it to be intended by Jackson, and use it for my critical edition.

Other Christian Union patterns that emerge I see as idiosyncratic, that is, not representing authorial intention. These for the most part constitute the rare occasions when it will differ from the Roberts Brothers punctuation: 
- The tendency to add exclamation marks into the middle of a sentence

- When Jackson writes that a character "exclaimed" or "asked" something and does not use an explanation mark or punctuation mark to accent the tone, the Christian Union will take these descriptions of how a character says something literally, always putting in a question mark or exclamation point

- When Jackson and Roberts Brothers use "towards" the periodical uses "toward"

- Spelling pretense as "pretence" and defense as "defence"

- When Jackson and Roberts Brothers use "farther" Christian Union uses "further"

For both the magazine and the first edition, I have found broad patterns of what I perceive as house style, or as regularizing grammatical clauses. In these cases, or when I judge that a punctuation mark revised by Roberts Brothers is so far outside of Jackson's usual punctuation style, I usually will not use the Christian Union/Roberts Brothers punctuation mark:

- Most instances of hyphenation

- Changing to a different mark where Jackson puts a comma after a word in order to set off dialogue

- Deleting commas before "that"; a characteristic of Jackson's style

- Revising Jackson's spellings (for example, from verandah to veranda) or capitals (South side to south side)

- Using a semicolon to mark the first part of dialogue, when the dialogue is interrupted by commentary or description (for example, "Yes, Señora," answered the mollified Juan; "the poor beasts look..." Roberts Brothers put a semicolon after Señora)

- The tendency of creating extra dependent clauses in the middle of sentences

- The tendency of putting commas to mark dependent clauses that begin or end sentences; this practice is grammatical, but not something Jackson tends to do. 
- The capitalization of words that start dialogue in the middle of a sentence (for example: "It had been always, "ask Señor Felipe," "go to Señor Felipe," "Señor Felipe will attend to it," ever since Felipe..." Roberts Brothers would capitalize "ask" and "go")

- Changing "Oh" into "O" when it starts a sentence

- Correcting all comma splices

Editorial Decisions Concerning Matters Besides the Text

Turning to problems of intention besides the body of a text, spacing is a problem that needs attention. Jackson had many more paragraph breaks in her manuscript that appear in either the periodical or first edition. For example, when a character had a very long piece of dialogue, at least a page long, she would break the dialogue into separate paragraphs, per topic. Both the Christian Union and Roberts Brothers were clearly focused on putting as much type on the page as possible, and leave such passages in one long text block. Her paragraph breaks in places besides dialogue are also changed. Interestingly, both the Christian Union and Roberts Brothers have the same paragraph breaks.

John Lennard explains that this was a typical $19^{\text {th }}$-century publishing practice, to have as few paragraph breaks as possible in order to use the most economical amount paper. Authors were forced to control their space in different ways, by having very long sentences with many colons, semicolons, and unusual punctuation, such as semicolon dashes (;--) or colon dashes (:--). ${ }^{48}$ Roberts Brothers takes away Jackson's control of her

\footnotetext{
${ }^{48}$ Lennard, John. "Mark, space, axis, function: towards a (new) theory of punctuation on historical principles" in Ma(r)king the Text: The Presentation of meaning on the literary page. Joe Bray, Miriam Handley, Anne C. Henry, eds. (Vermont: Ashgate Publishing Ltd, 2000), 7.
} 
space not only by changing her punctuation, but by changing her paragraph breaks. Part of recovering her intentions, then, is to restore her original conception of her novel's space, which simultaneously opens up the page by creating more white space and makes sentences denser.

Whether or not a critical edition should include illustrations is a question brought up by an assertion of Henry Sandham's, who was the illustrator for the three separate editions of the book that came out in 1900 . He had accompanied Jackson on her trip to California in the fall of 1881, the purpose of which was to gather material for her four articles on Southern California for the Century Magazine. He claims in his "Notes on Ramona Illustrations" in the 1900 Pasadena edition that

I was fortunate enough to travel in company with Mrs. Jackson at the time that she was accumulating the material for what has since become the best-known of all her books, and it was originally the plan that we should work together on it. Seventeen years, however, passed before I was able to finish my share of the work that Mrs. Jackson so graciously designated as "our book. ${ }^{49}$

As far as I have been able to find, there is no corroboration to Sandham's claim that it was "our book." Indeed, Jackson did not even have the idea for Ramona until October of 1883. Aldrich had suggested to her that she write a Southern California novel much earlier than this, but Jackson did not have clear plans for it while she was gathering materials for Century Magazine. ${ }^{50}$ Furthermore, Ruth Odell adamantly makes it clear that Jackson did not have the novel in mind during this trip. ${ }^{51}$ Because Sandham's claim that Jackson actively wanted him to illustrate her book cannot be substantiated, and because

\footnotetext{
${ }^{49}$ Sandham, Henry. Note on Illustrations in Ramona. Pasadena Edition. (Boston: Little, Brown and Company, 1900), xxxi.

${ }^{50}$ Phillips, Literary Life, 252

${ }^{51}$ Odell, Helen Hunt Jackson, 171.
} 
Jackson did not even have the specific idea for Ramona in mind when she and Sandham worked together, I do not include Sandham's illustrations in my critical edition.

\section{Rationale for Editing Chapters 1 and 26}

Within the confines of this project, I chose to edit chapter 1 because it is the veil that Jackson throws over her true intentions of getting readers interested in Indian rights. The chapter, as many have pointed out, barely mentions Native Americans at all, let alone their battles with the United States Government. Neither Ramona nor Alessandro makes an appearance. It innocuously features a debate over when to begin the ranch's sheep-shearing and reveals the internal power structures of the Moreno ranch.

In contrast, the last chapter of the novel, chapter 26, has abandoned all pretense of being about anything but a battle for Native American rights. It holds a deep anger about the injustice Native Americans faced in the judicial process and the low value that white people held Native American lives to hold. Jackson's experience with Indian Agencies, which were created to care for Native Americans on reservations, comes out strongly in this chapter, which contains a thinly disguised anger and frustration over their powerlessness and inefficacy. It is among the most criticized portions of the novel because of its apparently happy ending: Ramona marries Felipe and begins a happy life in Mexico. Truly, though, the ending is nothing but tragic. Ramona lives in body, but her spirit died with Alessandro. With this ending, Jackson predicts, that if nothing is done for Native Americans, they will first be destroyed in spirit, and then have no physical space at all in the United States. They will vanish, wrecked in both body and soul. 


\section{Chapter 1}

It was sheep-shearing time, in Southern California; but sheep-shearing was late at the Señora Moreno's. The fates had seemed to combine to put it off. In the first place, Felipe Moreno had been ill. He was the Señora's eldest son; and since his father's death had been at the head of his mother's house. Without him, nothing could be done on the

5 ranch, the Señora thought. It had been always, "ask Señor Felipe," "go to Señor Felipe," "Señor Felipe will attend to it," ever since Felipe had had the dawning of a beard on his handsome face.

In truth it was not Felipe, but the Señora, who really decided all questions from greatest to least, and managed everything on the place, from the sheep pastures to the artichoke patch; but nobody except the Señora herself knew this. An exceedingly clever woman for her day and generation was Señora Gonzaga Moreno,- - as for that matter, exceedingly clever for any day and generation; but exceptionally clever for the day and generation to which she belonged. Her life, the mere surface of it, if it had been written, would have made a romance, to grow hot and cold over: sixty years of the best of old Spain and the wildest of new Spain, Bay of Biscay, Gulf of Mexico, Pacific Ocean,- - the waves of them all had tossed destinies for the Señora. The Holy Catholic Church had had its arms round her from first to last; and that was what had brought her safe through, she would have said, if she had ever said anything about herself, which she never did, - one of her many wisdoms. So quiet so reserved so gentle an exterior never was known to veil

20 such an imperious, and passionate nature, brimful of storm, always passing through stress; - never thwarted, except at peril of those who did it; adored and hated by turns and each at the hottest. A tremendous force, wherever she appeared was Señora Moreno; but no stranger would suspect it, gliding about, in her scanty black gown, with her rosary hanging at her side, her soft dark eyes cast down, and an expression of mingled melancholy and devotion on her face. She looked simply like a sad spiritual minded old lady, amiable and indolent, like her race, but sweeter and more thoughtful than their wont. Her voice heightened this mistaken impression. She was never heard to speak either loud or fast. There was at times even a curious hesitancy in her speech, which came near being a stammer, or suggested the measured care with which people speak who have been cured of stammering. It made her often appear as if she did not know her own mind: at which people sometimes took heart when if they had only known, the truth, they would have known that the speech hesitated solely because the Señora knew her mind so exactly, that she was finding it hard to make the words convey it as she desired, or in a way to best attain her ends.

About this very sheep-shearing there had been, between her and the head shepherd, Juan Canito, called Juan Can, for short and to distinguish him from Juan Jose, the upper herdsman of the cattle, some discussions which would have been hot and angry ones in any other hands than the Señora's.

Juan Canito wanted the shearing to begin, even though Señor Felipe were ill in bed; and though that lazy shepherd Luigo had not yet got back with the flock, that had 
been driven up the coast for pasture. "There were plenty of sheep on the place to begin with," he said one morning, "at least a thousand;" and by the time they were done, Luigo would surely be back with the rest, and as for Señor Felipe's being in bed, had not he, Juan Canito, stood at the packing bag, and handled the wool, when Señor Felipe was a

5 boy? Why could he not do it again? The Señora did not realize how time was going; there would be no shearers to be hired presently; since the Señora was determined to have none but Indians; of course, if she would employ Mexicans as all the other ranches in the valley did, it would be different; but she was resolved upon having Indians, -

"God knows why," he interpolated surlily, under his breath;

"I do not quite understand you, Juan," interrupted Señora Moreno, at the precise instant the last syllable of this disrespectful ejaculation had escaped Juan's lips; "speak a little louder. I fear I am growing deaf in my old age."

What gentle, suave, courteous tones! and the calm dark eyes rested on Juan Canito with a look to the fathoming of which he was as unequal as one of his sheep would have been. He could not have told why he instantly, and involuntarily said,

"Beg your pardon Señora,"

"Oh you need not ask my pardon, Juan," the Señora replied with exquisite gentleness,

"It is not you who are to blame, if I am deaf. I have fancied for a year I did not

20 hear quite as well as I once did. But about the Indians, Juan; did not Señor Felipe tell you that he had positively engaged the same band of shearers we had last autumn, Alessandro's band from Temecula? They will wait until we are ready for them. Señor Felipe will send a messenger for them. He thinks them the best shearers in the country. He will be well enough in a week or two, he thinks, and the poor sheep must bear their loads a few days longer. Are they looking well, do you think Juan? Will the crop be a good one? General Moreno used to say that you could reckon up the wool crop to a pound, while it was on the sheep's backs."

"Yes, Señora," answered the mollified Juan; "the poor beasts look wonderfully well considering the scant feed they have had all winter. We'll not come many pounds short of our last year's crop, if any. Though, to be sure, there is no telling in what case that - Luigo will bring his flock back."

The Señora smiled in spite of herself, at the pause and gulp with which Juan had filled in the hiatus where he had longed to set a contemptuous epithet before Luigo's name.

This was another of the instances, when the Señora's will and Juan Canito's had clashed, and he did not dream of it, having set it all down as usual to the score of young Señor Felipe. Encouraged by the Señora's smile, Juan proceeded:

"Señor Felipe can see no fault in Luigo, because they were boys together, but I can tell him, he will rue it, one of these mornings, when he finds a flock of sheep worse than dead on his hands, and no thanks to anybody but Luigo. While I can have him under 
my eye, here in the valley, it is all very well; but he is no more fit to take responsibility of a flock, than one of the very lambs themselves. He'll drive them off their feet one day, and starve them the next; and I've known him to forget to give them water. When he's in his dreams, the Virgin only knows what he won't do."

5 During this brief, and almost unprecedented outburst of Juan's the Señora's countenance had been slowly growing stern. Juan had not seen it.

His eyes had been turned away from her, looking down into the upturned eager face of his favorite colley, who was leaping and gambolling and barking at his feet.

"Down, Capitan, down!" he said in a fond tone, gently repulsing him, "Thou makest such a noise, the Señora can hear nothing but thy voice."

"I heard only too distinctly, Juan Canito," said the Señora, in a sweet but icy tone. "It is not well for one servant to backbite another. It gives me great grief to hear such words; and I hope when Father Salvierderra comes next month, you will not forget to confess this sin of which you have been guilty in thus seeking to injure a fellow being. If Señor Felipe listens to you, the poor boy Luigo will be cast out homeless on the world some day; and what sort of a deed would that be, Juan Canito, for one Christian to do to another? I fear the Father will give you penance, when he hears what you have said."

"Señora, it is not to harm the lad," Juan began, every fibre of his faithful frame thrilling with a sense of the injustice of her reproach.

20 But the Señora had turned her back. Evidently she would hear no more from him then. He stood watching her as she walked away, at her usual slow pace, her head slightly bent forward, her rosary lifted in her left hand, and the fingers of the right hand mechanically slipping the beads.

"Prayers, always prayers!" thought Juan, to himself, as his eyes followed her. "If

25 they'll take one to Heaven, the Señora'll go by the straight road, that's sure! I'm sorry I vexed her. But what's a man to do, if he's the interest of the place at heart I'd like to know. Is he to stand by, and see a lot of idle mooning louts run away with everything? Ah, but it was an ill day for the estate when the General died,- - an ill day! an ill day! And they may scold me as much as they please, and set me to confessing my sins to the

30 Father, it's very well for them, they've got me to look after matters. Señor Felipe will do well enough when he's a man, maybe; but a boy like him! Bah!" and the old man stamped his foot with a not wholly unreasonable irritation, at the false position in which he felt himself put.

"Confess to Father Salvierderra indeed!” he muttered aloud. "Ay, that will I. He's

35 a man of sense, if he is a priest,_-" at which slip of the tongue, the pious Juan hastily crossed himself,_-_"and I'll ask him to give me some good advice, as to how I'm to manage between this young boy at the head of everything and a doting mother who thinks he's the wisdom of a dozen grown men. The Father knew the place in the olden time. He knows it's no child's play to look after the estate even now, much smaller as it 40 is! An ill day when the old General died, an ill day indeed, the saints rest his soul!" 
saying this, Juan shrugged his shoulders, and whistling to Capitan, walked towards the sunny verandah of the South side of the kitchen wing of the house, where it had been for twenty odd years his habit to sit on the long bench, and smoke his pipe of a morning. Before he had got half way across the court yard, however, a thought struck him. He

5 halted so suddenly that Capitan, with the quick sensitiveness of his breed, thought so sudden a change of purpose, could only come from something in connection with sheep, and true to his instinct of duty, pricked up his ears, poised himself for a full run, and looked up in his master's face waiting for explanation and signal. But Juan did not observe him.

"Ha!'” he said, "Father Salvierderra comes next month does he? Let's see. Today is the twenty fifth. That's it. The sheep-shearing is not to come off till the Father gets here; then each morning it will be mass in the chapel; and each night, vespers, and the crowd will be here at least two days longer to feed, for the time they will lose, by that and by the confessions. That's what Señor Felipe is up to. He's a pious lad. I recollect now, it

15 was the same way two years ago. Well, well, it is a good thing for those poor Indian devils to get a bit of religion now and then; and it's like old times to see the chapel full of them kneeling, and more than can get in the door; I doubt not it warms the Señora's heart to see them all there, as if they belonged to the house as they used to; and now I know when it's to be, I have only to make my arrangements accordingly. It is always in the first 20 week of the month the Father gets here. Yes! she said, 'Señor Felipe will be well enough in a week or two he thinks.' Ha! Ha, it will be nearer two; ten days or thereabouts. I'll begin the booths next week. A plague on that Luigo for not being back here. He's the best hand I have to cut the willow boughs for the roofs. He knows the difference between one year's growth and another's; I'll say that much for him, spite of the silly dreaming head

25 he's got on his shoulders.

Juan was so pleased with this clearing up in his mind as to Señor Felipe's purpose about the time of the sheep shearing, that it put him in good humor for the day,- - good humor with everybody, and himself most of all; as he sat on the low bench, his head leaning back against the white washed wall, his long legs stretched out nearly across the 30 whole width of the verandah, his pipe firm wedged in the extreme left corner of his mouth, his hands in his pockets, he was the picture of placid content. The troop of youngsters which still swarmed around the kitchen quarters of Señora Moreno's house, about as numerous and inexplicable as in the grand old days of the General's time, ran back and forth across Juan's legs, fell down between them, and picked themselves up by

35 help of clutches at his leather trousers all unreproved, by Juan, though loudly scolded and warned by their respective mothers from the kitchen.

"What's come to Juan Can to be so good natured today," saucily asked Margarita the youngest and prettiest of the maids, popping her head out of a window, and twitching Juan's hair. He was so gray and wrinkled, that the maids all felt at ease with him. He 40 seemed to them as old as Methuselah; but he was not really so old as they thought, nor 
they so safe in their tricks. The old man had hot blood in his veins yet, as the under shepherds could testify.

"The sight of your pretty face, Señorita Margarita," answered Juan quickly, cocking his eye at her, rising to his feet, and making a mock bow towards the window.

"He! He! Señorita, indeed!” chuckled Margarita's mother, old Marda the cook. "Señor Juan Canito is pleased to be merry at the doors of his betters," and she flung a copper saucepan full of not over clean water so deftly past Juan's head, that not a drop touched him, and yet he had the appearance of having been ducked. At which bit of sleight of hand, the whole court yard, young and old, babies, cocks, hens, and turkeys all set up a shout and a cackle, and dispersed to the four corners of the yard as if scattered by a volley of bird shot. Hearing the racket, the rest of the maids came running, - Anita, and Maria the twins, women forty years old, born on the place, the year after General Moreno brought home is handsome young bride; - their two daughters Rosa, and Anita the Little, as she was still called, though she outweighed her mother; old Juanita the oldest woman in the household, of whom even the Señora was said not to know the exact age or history, and she poor thing could tell nothing having been silly for ten years or more, good for nothing except to shell beans: that she did as fast and well as ever, and was never happy except she was at it. Luckily for her, beans are the one crop never omitted, or stinted on a Mexican estate, and for sake of old Juanita they stored every year in the Moreno house,

20 rooms full of beans in the pod; (tons of them, one would think) enough to feed an army. But then, it was like a little army even now, the Señora's household; nobody ever knew exactly how many women were in the kitchen or how many men in the fields. There were always women cousins, or brother's wives or widows, or daughters who had come to stay, or men cousins, or sister's husbands or sons who were stopping, on their way up or down the valley. When it came to the pay roll, Señor Felipe knew to whom he paid wages; but who were fed and lodged under his roof that was quite another thing. It could not enter into the head of a Mexican gentleman to make either count or account of that. It would be a disgraceful niggardly thought.

To the Señora, it seemed as if there were no longer any people about the place, a beggarly handful, she would have said, hardly enough to do the work of the house, or of the estate, sadly as the latter had dwindled. In the General's day, it had been a freehanded boast of his that never less than fifty persons, men women and children were fed within his gates each day, how many more, he did not care, nor know. But that time had indeed gone, gone forever; and though a stranger, seeing the sudden rush and muster at door and

35 window which followed on old Marda's letting fly the water at Juan's head, would have thought, "good Heavens do all those women children and babies belong in that one house!",- - the Señora's sole thought as she at that moment, went past the gate, was,

"Poor things; how few there are left of them! I am afraid old Marda has to work too hard, I must spare Margarita more from the house to help her!" and she sighed 40 deeply, and unconsciously held her rosary nearer to her heart, as she went into the house, 
and entered her son's bedroom. The picture she saw there was one to thrill any mother's heart; and as it met her eye, she paused on the threshold for a second,- - only a second, however, and nothing could have astonished Felipe Moreno so much as to have been told that at the very moment when his mother's calm voice was saying to him,

"Good morning, my son. I hope you have slept well, and are better," there was welling up in her heart a passionate ejaculation, "Oh my glorious son; the Saints have sent me in him the face of his father! He is fit for a kingdom!"

The truth is, Felipe Moreno was not fit for a kingdom at all. If he had been, he would not have been so ruled by his mother without ever finding it out. But so far as mere physical beauty goes, there never was a king born, whose face, stature and bearing would set off a crown or a throne, or any of the things of which the outside of royalty is made up, better than would Felipe Moreno's.

And it was true, as the Señora said, whether the Saints had anything to do with it or not, that he had the face of his father. So strong a likeness is seldom seen. When Felipe once, on the occasion of a grand celebration, and procession put on the gold wrought velvet mantle, gaily embroidered short breeches fastened at the knee with red ribbons, and gold and silver trimmed sombrero, which his father had worn, twenty- five years before, the Señora fainted at the first look at him,- - fainted and fell; and when she opened her eyes, and saw the same splendid, gaily arrayed, dark bearded man, bending over her in distress with words of endearment and alarm, she fainted again.

"Mother, mother mia," cried Felipe,

"I will not wear them, if it makes you feel like this! Let me take them off. I will not go to this cursed parade," and he sprang to his feet and began with trembling fingers to unbuckle the sword belt.

"No, no, Felipe" faintly cried the Señora, from the ground. "It is my wish that you wear them;" and staggering to her feet, with a burst of tears, she re-buckled the old sword belt which her fingers had so many times - never un-kissed-buckled, in the days when her husband had bade her fare well, and gone forth to the un-certain fates of war.

"Wear them!" she cried, with gathering fire in her tones, and her eyes dry of tears, - "wear them, and let the American hounds see what a Mexican officer, and gentleman looked like, before they had set their base, usurping feet on our necks!" And she followed him to the gate, and stood erect, bravely waving her handkerchief, as he gallopped off, till he was out of sight. Then, with a changed face, and a bent head she crept slowly to her room, locked herself in, fell on her knees before the Madonna at the

35 head of her bed, and spent the greater part of the day praying that she might be forgiven, and that all heretics might be discomfited. From which part of these supplications she derived most comfort, is easy to imagine.

Juan Canito had been right in his sudden surmise that it was for Father Salvierderra's coming that the sheep shearing was being delayed, and not in consequence of Señor Felipe's illness, or of the non appearance of Luigo and his flock of sheep, Juan 
would have chuckled to himself still more, at his perspicacity had he over-heard the conversation going on between the Señora and her son, at the very time, when he, half asleep on the verandah was, as he would have called it, putting two and two together and convincing himself that old Juan was as smart as they were, and not to be kept in the dark 5 by al their reticence and equivocation.

"Juan Can, is growing very impatient about the sheep shearing," said the Señora. "I suppose you are still of the same mind about it, Felipe,- - that it is better to wait till Father Salvierderra comes? As the only chance those Indians have of seeing him, is here, it would seem a Christian duty to so arrange it, if it be possible; but Juan is very restive.

10 He is getting old, and chafes a little I fancy under your control. He cannot forget that you were a boy on his knee. Now, I, for my part, am like to forget that you were ever anything but the man for me to lean on."

Felipe turned his handsome face toward his mother, with a beaming smile of filial affection, and gratified manly vanity.

15 "Indeed, my mother, if I can be sufficient for you to lean on, I will ask nothing more of the Saints," and he took his mother's thin and wasted little hands, both at once, in his own strong right hand, and carried them to his lips as a lover might have done. "You will spoil me mother," he said, "You make me so proud."

"No, Felipe, it is I who am proud," promptly replied the mother, "and I do not call

20 it being proud; only grateful to God, for having given me a son wise enough to take his father's place, and guide and protect me, through the few remaining years I have to live. I shall die content seeing you at the head of the estate, and living as a Mexican Gentleman should, that is, so far as now remains possible in this unfortunate country. But about the sheep shearing, Felipe. Do you wish to have it begun before the Father is here? Of course Alessandro is all ready with his band. It is but two days' journey for a messenger to bring him. Father Salvierderra cannot be here before the tenth of the month. He leaves Santa Barbara on the first; and he will walk all the way, - a good six days journey, for he is old now and feeble; then he must stop in Ventura for a Sunday, and a day at the Ortegna's ranch, and at the Lopez's; - there, there is a christening. Yes the tenth is the very earliest

30 that he can be here, - - near two weeks from now. So far as your getting up is concerned, it might perhaps be next week. You will be nearly well by that time."

"Yes indeed," laughed Felipe, stretching himself out in the bed, and giving a kick to the bedclothes that made the high bed- posts and the fringed canopy roof shake and creak, "I am well now, if it were not for this cursed weakness when I stand on my feet. I

35 believe it would do me good to get out of doors."

In truth Felipe had been hankering for the sheep-shearing, himself. It was a brisk busy, holiday sort of time to him, hard as he worked, in it; and two weeks looked long to wait.

"It is always thus after a fever," said his mother, "The weakness lasts many weeks. I am not sure that you will be strong enough even in two weeks to do the packing; 
but as Juan Can, said this morning, he stood at the packing-bag when you were a boy, and there was no need of waiting for you, for that!"

"He said that, did he," exclaimed Felipe, wrathfully. "The old man is getting insolent. I'll tell him, that nobody will pack the sacks but myself, while I am master

5 here; - and I will have the sheep shearing when I please and not before."

"I suppose it would not be wise to say, that it is not to take place, till the Father comes, would it?" asked the Señora, hesitatingly, as if the thing were evenly balanced in her mind. "The Father has not that hold on the younger men, he used to have; and I have thought that even in Juan himself I have detected a remissness. The spirit of un-belief is

10 spreading in the country since the Americans are running up and down everywhere, seeking money like dogs with their noses to the ground! It might vex Juan if he knew that you were waiting only for the Father. What do you think?"

"I think it is enough for him to know that the sheep shearing waits for my pleasure," answered, Felipe, still wrathful, "and that is the end of it." And so it was; and moreover, precisely then end which Señora Moreno had had in her own mind from the beginning; but not even Juan Canito himself, suspected, of its being solely her purpose, and not her son's. As for Felipe, if any person had suggested to him, that it was his mother, and not he, who had decided that the sheep shearing would better be deferred until the arrival of Father Salvierderra, from Santa Barbara, and that nothing should be

20 said on the ranch about this being the real reason of the postponing, Felipe would have stared in astonishment, and have thought that person either crazy or a fool.

To attain one's ends in this way, is the consummate triumph of art. Never to appear as a factor in the situation; to be able to wield other men, as instruments, with the same direct and implicit response to will that one gets from a hand or a foot, - this is to

25 triumph, indeed; to be as nearly controller and conqueror of Fates, as Fate permits. There have been men prominent in the world's affairs at one time and another, who have sought and studied such a power, and have acquired it to a great degree. By it, they have manipulated legislators, ambassadors, sovereigns; and have grasped held and played with, the destinies of empires. But it is to be questioned whether even in these notable

30 instances, there has ever been so marvelous completeness of success, as is sometimes seen in the case of a woman in whom the power is an instinct, and not an attainment; a passion rather than a purpose. Between the last two results, between the two processes, there is just that difference which is always to be seen between the stroke of talent, and the stroke of genius.

Señora Moreno's was the stroke of genius. 


\section{Chapter 26}

The Capitan's house faced the East. Just as day broke, and the light streamed in at the open door, Ramona's eyes unclosed. Felipe and Aunt Ri both were by her side. With a look of bewildered terror, she gazed at them.

"Thar! Thar, naow, yer jest shet yer eyes 'n go right off ter sleep agin, honey," said Aunt Ri, composedly, laying her hand on Ramona's eyelids and compelling them down. 'We air hyar, Feeleepy 'n' me, 'n' we air goin' to stay. I allow yer needn't be affeerd o' nothin'; go ter sleep honey."

The eyelids quivered beneath Aunt Ri's fingers. Tears forced their way, and rolled slowly down the cheeks. The lips trembled; the voice strove to speak, but it was only like the ghost of a whisper, the faint question that came,

"Felipe?"

"Yes dear! I am here too," breathed Felipe. "Go to sleep. We will not leave you!" And again Ramona sank away into the merciful sleep which was saving her life.

"Ther longer she she kin sleep, ther better," said Aunt Ri with a sigh deep drawn

15 like a groan, "I allow I dread ter see her reely come to. 'T'll be wus'n the fust; she'll hev ter live it all over agin!"

But Aunt Ri did not know what forces of fortitude had been gathering in Ramona's soul, during these last bitter years. Out of her gentle constancy, had been woven the heroic fibre of which martyrs are made; this and her inextinguishable faith had made her strong, as were those of old, who - "had trial of cruel mocking, wandered about being destitute afflicted tormented, wandered in deserts and in mountains, and in dens and caves of the earth."

When she waked the second time, it was with a calm almost beatific smile that she gazed on Felipe, and whispered, "How did you find me dear Felipe?" It was rather by

25 the motions of her lips than by any sound that he knew the words. She had not yet strength enough to make an audible sound. When they laid her baby on her breast, she smiled again; and tried to embrace her, but was too weak.

Pointing to the baby's eyes, she whispered, gazing earnestly at Felipe,

"Alessandro." A convulsion passed over her face as she spoke the word, and the tears flowed. Felipe could not speak. He glanced helplessly at Aunt Ri, who promptly responded,

'Naow, honey, don't yeow talk. T'ain't good fer ye; 'n' Feeleepy 'n' me, we air in a powerful hurry ter git yer strong ' $n$ ' well, 'n' tote ye out er this_-” Aunt Ri stopped. No substantive in her vocabulary answered her need at that moment. "I allow ye kin go

35 'n' a week ef nothin' don't go agin ye, more 'n' I see naow; but ef yer git ter talkin', thar's no tellin' when yer'll git up. Yeow jest shet up honey. We'll look arter everything."

Feebly Ramona turned her grateful inquiring eyes on Felipe. Her lips framed the words, "With you?"

"Yes dear. Home with me," said Felipe, clasping her hand in his. "I have been 
An anxious look came into the sweet face. Felipe knew what it meant. How often he had seen it in the olden time. He feared to shock her by the sudden mention of the Señora's death; yet that would harm her less than continued anxiety.

"I am alone, dear Ramona," he whispered. "There is no one now but you, my sister, to take care of me. My mother has been dead a year."

The eyes dilated, then, filled with sympathetic tears;

"Dear Felipe," she sighed; but her heart took courage. Felipe's phrase was like one inspired; another duty, another work, another loyalty waiting for Ramona. Not only her child to live for, but to "take care of Felipe!" Ramona would not die! Youth, a mother's love, a sister's affection and duty, on the side of life; - the battle was won; and won quickly, too.

To the simple Cahuillas it seemed like a miracle; and they looked on Aunt Ri's weather beaten face with something akin to a superstitious reverence. They themselves were not ignorant of the value of the herb by means of which she had wrought the marvellous cure; but they had made repeated experiments with it upon Ramona, without success. It must be that there had been some potent spell in Aunt Ri's handling. They would hardly believe her when in answer to their persistant questioning, she reiterated the assertion that she had used nothing except the hot water, and "old man," which was her name for the wild wormwood; and which when explained to them, impressed them

20 greatly, as having no doubt some significance in connection with the results of her preparation of the leaves.

Rumors about Felipe ran swiftly throughout the region. The presence in the Cahuilla village, of a rich Mexican gentleman who spent gold like water, and kept mounted men riding day and night, after everything, anything he wanted for his sick

25 sister, was an event which in the atmosphere of that lonely country, loomed into colossal proportions. He had travelled all over California, with four horses, in search of her. He was only waiting till she was well, to take her to his home, in the South, and then he was going to arrest the man who had murdered her husband, and have him hanged, yes hanged! Small doubt about that; or, if the law cleared him, there was still the bullet. This rich Señor, would see him shot, if rope were not to be had. Jim Farrar heard these tales, and quaked in his guilty soul. The rope he had small fear of, for well he knew the temper of San Diego County juries and judges; but the bullet, that was another thing: and these Mexicans were like Indians in their vengeance. Time did not tire them, and their memories were long. Farrar cursed the day he had let his temper get the better of him on

35 that lonely mountain side; how much the better, nobody but he himself knew; nobody but he, and Ramona; and even Ramona did not know the bitter whole. She knew that Alessandro had no knife, and had gone forward with no hostile intent; but she knew nothing beyond that. Only the murderer himself knew, that the dialogue which he had reported to the judge and jury, to justify his act, was an entire fabrication of his own, and that instead of it, had been spoken but four words by Alessandro, and those were, 
"Señor, I will explain," and that even after the first shot had pierced his lungs, and the blood was choking in his throat, he had still run a step or two farther, with his hand uplifted deprecatingly, and made one more effort to speak, before he fell to the ground dead. Callous as Farrar was, and clear as it was in his mind that killing an Indian was no

5 harm, he had not liked to recal the pleading anguish in Alessandro's tone and in his face, as he fell. He had not liked to recal this, even before he heard of this rich Mexican brother-in-law who had appeared on the scene, and, now, he found the memories still more unpleasant. Fear is a wonderful goad to remorse. There was another thing too which to his great wonder, had been apparently overlooked by everybody; at least nothing had been said about it; but the bearing of it on his case, if the case was brought up a second time and minutely investigated, would be most unfortunate; and this was, that the only clue he had to the fact of Alessandro's having taken his horse, was that the poor half crazed fellow had left his own well known gray pony in the corral in place of the horse he took. A strange thing surely for a horse thief to do! Cold sweat burst out on Farrar's

15 forehead, more than once, as he realized how this, coupled with, the well known fact of Alessandro's liability to attacks of insanity, might be made to tell against him, if he should be brought to trial for the murder. He was as cowardly as he was cruel: never yet were the two traits separate, in human nature; - and after a few days of this torturing suspense and apprehension, he suddenly resolved to leave the country; if not forever, at

20 least for a few years, till this brother-in-law should be out of the way. He lost no time, in carrying out his resolution; and it was well he did not; for it was only three days after he had disappeared, that Felipe walked into Judge Wells's office one morning to make inquiries relative to the preliminary hearing which had been held there in the matter of the murder of the Indian Alessandro Assis by James Farrar. And when the Judge, taking

25 down his books, read to Felipe his notes of the case, and went on to say, "if Farrar's testimony is true, Ramona's the wife's must be false," and at any rate, "her testimony would not be worth a straw with any jury," Felipe sprang to his feet, and cried,

"She of whom you speak is my foster sister, and by God, Señor, if I can find that man, I will shoot him, as I would a dog! And I'll see, then, if a San Diego County jury will hang me for ridding the country of such a brute," and Felipe would have been as good as his word. It was a wise thing Farrar had done in making his escape.

When Aunt Ri heard that Farrar had fled the country, she pushed up her spectacles and looked reflectively at her informant. It was young Merrill.

"Fled ther country, hez he?" she said. "Wall he kin flee ez many countries ez he

35 likes an't won't dew him no good. I know yeow folks hyar don't seem ter think killin' an Indian 's enny murder, but I say tis; an' yeow'll all git it brung home ter yer, afore yer die; ef't ain't brung one way, 't'll be anuther; yeow jest mind what I say, 'n' don't yeow furgit it. Naow this miserable murderer, this Farrar thet's lighted out er hyar, he's nothin' more 'n' a skunk, but he's got the Lawd arter him naow. It's jest 's well he's gawn: I never did b'leeve in hangin'. I never could. It's jest tew men dead 'stead 'o one; I don't 
want to see no man hung; no marter what he's done. 'N' I don't want to see man shot down, nuther; no marter what he's done; 'n' this hyar Feeleepy, he's thet high strung, he'd ha' shot thet Farrar any minnit, quicker 'n lightning, ef he'd ketched him; so it's better all raound, he's lit about. But I tell yeow naow, he hain't made much by goin'!

5 Thet Injun he murdered'll foller him, night 'n' day, till he dies, 'n' long arter; he'll wish he wuz dead, afore he does die, I allow he will, naow. He'll be jest like a man, I knowed back in Tennessee; I wan't but a mite then; but I never forgot it. 'T's a great country for gourds East Tennessee is, whar I was raised; 'n' there wuz two houses, 'n' a fence between 'em, ' $n$ these gourds a runnin' all over the fence; 'n' one 'o ther children picked one 'o them gourds, an' they fit about it; ' $n$ ' then the women took it up, - ther children's mothers yer know, - ' $n$ ' they got fightin' abaout it, ' $n$ ' then 't the last, the men took it up, 'n' they fit; ' $n$ ' Rowell he got his butcher knife, ' $n$ ' he ground it up, ' $n$ ' he picked a quirril with Claiborne, $n$ ' he cut him inter pieces. They hed him up for't, 'n' somehow, they clared him. I don't see how they ever did, but they put't off ' $n$ ' put't off, 'n' 't last they got him free; ' $n$ ' he lived on thar a spell, but he couldn't stan' it; 'peared like he never hed no peace; ' $n$ ' he come over ter us, ' $n$ ' sed he,

'Jake', - they allers called daddy 'Jake,' or 'Uncle Jake',_ 'Jake', sed he, I can't stan' it, livin' hyar."

'Why, sez daddy, the law and the country's clar'd ye.'

20 'Yes, sez he, but the law o' God hain't; 'n' I've got Claiborne allers with me. Thar ain't any path so narrer but he's a walkin' in it, by my side, all day, 'n' come night, I sleep with him ter one side, 'n' my wife t'other, 'n' I can't stan' it!'

Them's ther very words I heered him say, 'n' I wusn't anythin' but a mite, but I didn't furgit it.

Wall sir, he went West, way aout hyar to Californy, ' $n$ ' he couldn't stay thar nuther, 'n' he come back hum agin, 'n' I was bigger then, a gal grown, 'n' daddy sez to him,--I heern him,-

'Wal! sez he, 'did Claiborne foller yer?'

'Yes,' sez he, 'He follered me; I'll never git shet o' him, in this world. He's allers

30 clos't to me everywhar.'

Yer see, 't was jest his conscience er whippin' him. Thet's all 'twas. 'T least, thet's all I think 't was; though thar wuz those thet said 't was Claiborne's ghost. ' $N$ ' thet'll be the way t'll be with this miserable Farrar; he'll live ter wish he'd let himself be hanged, or shot, or erry which way ter git out er his misery!"

Young Merrill listened with unwonted gravity to Aunt Ri's earnest words. They reached a depth in his nature which had been long untouched, a stratum, so to speak, which lay far beneath the surface. The character of the western frontiers man, is often a singular accumulation of such strata - the training and beliefs of his earliest days, overlain by successions of unrelated and violent experiences, like geological deposits.

40 Underneath the exterior crust of the most hardened and ruffianly nature often remains- 
its forms not yet quite fossilized - a realm full of the devout customs, doctrines, religious influences, which the boy knew, and the man remembers. By sudden upheaval, in some great catastrophe or struggle in his mature life, these all come again into the light. Assembly Catechism definitions which he learned in his childhood, and has not thought of since, ring in his ears; and he is thrown into all manner of confusions and inconsistencies of feeling and speech, by this clashing of the old and new man within him. It was much in this way that Aunt Ri's words smote upon young Merrill. He was not many years removed from the sound of a preaching of the straitest New England Calvinism. The wild frontier life had drawn him in, and under, as in a whirlpool; but he was New Englander yet, at heart.

“That's so Aunt Ri!" he exclaimed. "That's so. I don't spose a man that's committed murder'll ever have any peace, in this world nor in the next nuther, without he repents; but ye see, this horse stealin' business is different. 'T'ain't murder to kill a hoss thief, any way you can fix it; everybody admits that; a feller that's caught horse stealin' had ought to be shot; and he will be too, I tell you, in this country!"

A look of impatient despair spread over Aunt Ri's face.

“I hain't no patience left with yer," she said, “er talkin' abaout stealin' hosses, ez ef hosses wuz more'n human bein's! But lettin' thet all go, this Injun, he wuz crazy. Yer all knowed it. Thet Farrar knowed it. D'yer think ef he'd ben stealin' the hoss, he'd er left

20 his own hoss in the corral, same ez you might say leavin his kyerd to say 't wuz he done it? ' $N$ ' the hoss er tied in plain sight 'n' front uv his house, fur anybody ter see?"

"Left his own horse, so he did!" retorted Merrill. "A poor miserable knockneed old pony, that wan't worth twenty dollars; 'n' Jim's horse wuz worth two hundred, 'n' cheap at that."

"Thet ain't nuther here nor thar, in what we air sayin'," persisted Aunt Ri. "I ain't a speakin' on't ez a swap er hosses; what I say is, he wan't lyin' to cover't up thet he'd tuk the hoss. We air sum used ter hoss thieves in Temecula, but I never heered o' one yit, thet left his name fur a refference behind him, ter show which road he tuk, 'n fastened ther stolen critter ter his front gate when he got hum! I allow me 'n yeow hedn't better say anythin' much more on the subjeck, fur I allow we air bound to querril ef we dew;" and nothing that Merrill said could draw another word out of Aunt Ri, in regard to Alessandro's death. But there was another subject on which she was tireless, and her speech eloquent. It was the kindness and goodness of the Cahuilla people. The last vestige of her prejudice against Indians had melted and gone, in the presence of their simple hearted friendliness.

"I'll never hear a word said agin em, never, ter my longest day," she said. "The way the pore things hed jest stripped theirselves, to git things fur Ramony, beat all ever I see, among white folks, 'n' I've ben raound more 'n' most; 'n' they wan't lookin' fur no pay, nuther; fur they didn't know till Feeleepy ' $n$ ' me cum, thet she hed any folks anywhar, 'n' they'd ha' taken care on her till she died, jest the same. The sick allers ez 
took care on, among them, they sed, 's' long ez enny on em hez got a thing left. That's ther way they air raised. I allow white folks might take a lesson on 'em, in thet; ' $n$ ' in heaps uv other things tew. Oh, I'm done talkin' agin Injuns, naow don't yeow furgit it! But I know fur all that, 't won't make any difference; 'pears like thar cuddn't nobody

5 b'leeve ennythin ' $n$ ' this world 'though seein ' $t$ their selves. I wuz thet way tew; I allow I hain't got no call ter talk; but I jest wish the hull world could see what I've seen! Thet's all!"

It was a sad day in the village when Ramona and her friends departed. Heartily as the kindly people rejoiced in her having found such a protector for herself and her child,

10 and deeply as they felt Felipe's and Aunt Ri's good will and gratitude toward them, they were yet conscious of a loss, - of a void. The Gulf between them, and the rest of the world, seemed defined anew; their sense of isolation deepened; their hopeless poverty emphasized. Ramona, wife of Alessandro, had been as their sister,- - one of them; as such, she would have had share in all their life had to offer; but its utmost was nothing but

15 hardship and deprivation; and she was being borne away from it, like one rescued, not so much from death as from a life worse than death.

The tears streamed down Ramona's face as she bade them farewell. She embraced again and again, the young mother who had for so many days suckled her child, even, it was said, depriving her own hardier babe, that Ramona's should not suffer.

20 "Sister! You have given me my child," she cried. "I can never thank you! I will pray for you all my life."

She made no inquiries as to Felipe's plans. Unquestioningly, like a little child, she resigned herself into his hands. A power greater than hers was ordering her way; Felipe was its instrument. No other voice spoke to guide her. The same old simplicity of

25 acceptance which had characterized her daily life in her girlhood, and kept her serene and sunny then,-_-serene under trials, sunny in her routine of little duties,- - had kept her serene through all the afflictions, and calm if not sunny, under all burdens, of her later life, and it did not desert her even now.

Aunt Ri gazed at her with a sentiment as near to veneration as her dry humorous

30 practical nature was capable of feeling.

"I allow I donno but I sh'd cum ter believin' in Saints tew," she said, "ef I wuz ter live 'long sider er thet gal. Pears like she wuz suthin' more ' $n$ ' human. 'T beats me plum out, ther way she takes her troubles. Thar's some would say she hedn't no feelin'; but I allow she hez more'n most folks. I kin see't ain't thet. I allow I didn't never expect ter

35 think 's well uv prayin' to picters 'n strings er beads 'n sech; but ef it's thet keeps her up ther way she's kept up, I allow thar's more in it ' $n$ ' its hed credit fur. I ain't gwine ter say enny more agin it, nor agin Injuns. Pears like I'm gettin' heaps er new ideas inter my head, these days. I'll turn Injun mebbe afore I git through!"

The farewell to Aunt Ri was hardest of all. Ramona clung to her as to a mother.

40 At times, she felt that she would rather stay by her side, than go home with Felipe; then 
she reproached herself for the thought as for a treason and ingratitude. Felipe saw the feeling, and did not wonder at it. "Dear girl," he thought, "it is the nearest she has ever come to knowing what a mother's love is like!" And he lingered in San Bernardino, week after week, on the pretence that Ramona was not yet strong enough to bear the journey

5 home, when in reality his sole motive for staying was his reluctance to deprive her of Aunt Ri's wholesome and cheering companionship.

Aunt Ri was busily at work on a rag carpet for the Indian Agent's wife. She had just begun it, had woven only a few inches, on that dreadful morning when the news of Alessandro's death reached her. It was of her favorite pattern, the "hit-er-miss" pattern as she called it: no set stripes, or regular alternation of colors; but ball after ball of the indiscriminately mixed tints, woven back and forth, on a warp of a single color. The constant variety in it, the unexpectedly harmonious blending of the colors, gave her delight, and afforded her a subject too of not unphilosophical reflection.

"Wall," she said, "it's called the 'hit-er-miss' pattern; but it's 'hit' oftener 'n' tis 'miss'. Thar ain't enny accountin' fur ther way ther breadths'll come, sometimes; pears like 't wuz kind er magic, when they air sewed tergether; 'n' I allow thet's ther way it's gwine ter be with heaps er things in this life. It's jest a kind er 'hit-er-miss' pattren we air all on us livin' on; t'ain't much use tryin' ter reckon how ' $t$ 'll come aout; but the breadth's doos fit heaps better ' $n$ ' yer 'd think; come ter sew em, t'aint never no sech

20 colors ez yer thought 't wuz gwine ter be, but it's allers pooty, allers; never see a 'hit-ermiss' pattren ' $n$ ' my life yit thet wa'n't pooty; ' $n$ ' thar want never nobody fetched me rags, 'n' hed em all planned aout, 'n' jest ther way they wanted ther warp, 'n' jest haow the stripes wuz ter come, 'n' all, thet they wan't orful diserpynted when they cum ter see 't done. It don't never look 's' they thought 't would, never!

I larned thet lesson airley; 'n' I allers make em, write 't aout on a paper, jest ther wedth er every stripe, ' $n$ ' each er ther colors, so 's they kin see, it's what they ordered; ' $r$ else they'd allers say I hedn't wove 't' s I wuz told ter. I got ketched thet way oncet! I allow ennybody's a bawn fool gits ketched twice runnin', ther same way.

But fur me, I'll take the 'hit-er-miss' pattern, every time sir, straight along."

When the carpet was done, Aunt Ri took the roll in her own independent arms, and strode with it to the Agent's house. She had been biding the time when she should have this excuse for going there. Her mind was burdened with questions she wished to ask, information she wished to give, and she chose an hour when she knew she would find the Agent himself at home.

"I allow yer heered why I was behind time with this yere carpet," she said, "I wuz up ter San Jacinto Mounting, whar thet Injun wuz murdered. We brung his widder ' $n$ ' the baby daown with us, me ' $n$ ' her brother. He's tuk her home ter his house ter live. He's reel well off."

Yes, the Agent had heard this; he had wondered why the widow did not come to see him; he had expected to hear from her. 
"Wall, I did hent ter her thet praps yer could dew something, ef she wuz ter tell yer all abaout it; but she allowed thar wan't enny use in talkin'. Ther Jedge, he sed her witnessin' wouldn't be wuth nothin' to no jury; 'n' thet wuz what I wuz a wantin' to ask yeow, ef thet wuz so."

"Yes, that is what the lawyers here told me," said the Agent, "I was going to have the man arrested, but they said it would be folly to bring the case to trial. The woman's testimony would not be believed."

"Yeow've got power to git a man punished fur sellin' whisky to Injuns, I notice," broke in Aunt Ri, "hain't yer? I see yeour man 'n' the Marshall here arrestin' em pooty lively last month; they sed 'twas yeour doin'. Yeow was a gwine ter prossacute every livin' son o' hell,-— them wuz thar words, - thet sold whiskey ter Injuns."

"That's so!" said the Agent, "so I am, I am determined to break up this vile business of selling whiskey to Indians. It is no use trying to do anything for them while they are made drunk in this way. It's a sin and a shame."

"Thet's so, I allow ter yeow," said Aunt Ri; "thar aren't any gainsayin' thet. But ef yeow've got power ter git a man put in jail fur selling whiskey ' $t$ ' ' $n$ Injun, ' $n$ ' hain't got power ter git him punished ef he goes ' $n$ ' kills thet Injun, 't seems ter me thar's suthin' cur'us abaout thet."

"That is just the trouble in my position here, Aunt Ri," he said." I have no real 20 power over my Indians as I ought to have."

"What makes yer call em yeour Injuns?" broke in Aunt Ri.

The Agent colored. Aunt Ri was a privileged character, but her logical method of questioning was inconvenient.

"I only mean that they are under my charge," he said. "I don't mean that they

25 belong to me in any way."

"Wall, I allow not," retorted Aunt Ri, “enny more 'n' I dew. They air airnin their livin' sech 's tis, ef yer kin call it a livin'. I've been mongst em naow this hyar last tew weeks, 'n' I allow I've hed my eyes opened ter some things.

"What's thet doctor er yourn him thet they call the agency docter,-what's he got 30 ter do?"

"To attend to the Indians of this Agency when they are sick," replied the Agent promptly.

"Wall, thet's what I heern; thet's what yeow sed afore, 'n' thet's why Alessandro, the Injun thet wuz murdered, - - thet's why he put his name down 'n' yeour books, though

35 't went agin him orful ter do it; he wuz high spereted; ' $n$ ' ' $d$ allus took keer er hisself; but he'd ben druv out er first one place ' $n$ ' then another, tell he'd got clar down, ' $n$ ' pore; ' $n$ ' he jest begged thet docter er yourn to go to see his little gal, 'n' the docter wouldn't; 'n' more ' $n$ ' thet, he laughed at him, fur askin', 'n' they set the little thing on the hoss ter bring her here, 'n' she died afore they'd came a mile with her, ' $n$ ' $t$ ' was thet on top er all the rest, druv Alessandro crazy. He never hed none er them wandrin' speels till arter thet. 
Naow I allow thet wan't right er thet docter. I wouldn't hev no sech docter's thet raound my agency, ef I wuz yeow. Praps yer never heered uv thet. I told Ramony, I didn't bleeve yer knowed it, or ye'd hev made him go."

"No! Aunt Ri," said the Agent. "I could not have done that. He is only required to

5 doctor such Indians as come here."

"I allow then, thar ain't any gret use en hevin' him at all," said Aunt Ri, "pears like thar ain't more'n a handful uv Injuns raound here. I expect he gits well paid?" and she paused for an answer. None came. The Agent did not feel himself obliged to reveal to Aunt Ri what salary the Government paid the San Bernardino doctor for sending hap hazard prescriptions to Indians he never saw.

After a pause Aunt Ri resumed,

"Ef it ain't enny offence ter yeow, I allow I'd like tew know jest what tis yeow air here ter dew fur these Injuns. I've got my feelins considdable stirred up, being' among em, 'n' knowin' this hyar one, thets ben murdered. Hev ye got enny power to giv 'em ennything,- - food or sech? They air powerful pore, most on em."

"I have had a little fund for buying supplies for them, in times of special suffering; replied the Agent, "a very little; and the department has appropriated some money for wagons and ploughs; not enough however to supply every village; you see these Indians are in the main self supporting."

20 "Thet's jest it;" persisted Aunt Ri. “Thet's what I've been seein': 'n' thet's why I want so bad ter git at what tis the Guvvermunt means ter hev yeow dew fur em; I allow ef yeow ain't ter feed 'em, an' ef yer can't put folks inter jail fur robbin' 'n' cheatin' 'em, not ter say killin' 'em, - ef yer can't dew anythin' more 'n' keep 'em from gettin' whiskey, wall, I'm free ter say_-”

Aunt Ri paused; she did not wish to seem to reflect on the Agent's usefulness, and so, concluded her sentence very differently from her first impulse,-_ "I'm free ter say, I shouldn't like ter stan' in yer shoes!"

"You may very well say that Aunt Ri" laughed the Agent complacently. "It is the most troublesome Agency in the whole list, and the least satisfactory."

"Wall I allow it mought be the least satisfyin'," rejoined the indefatigable Aunt $\mathrm{Ri}$, "but I donno whar the trouble comes in, ef so be's thar's no more kin be done than yer wuz er tellin'." And she looked honestly puzzled.

"Look there Aunt Ri!" said he triumphantly, pointing to a pile of books and papers. "All those to be gone through with, and a report to be made out every month, and

35 a voucher to be sent for every lead pencil I buy; I tell you I work harder than I ever did in my life before, and for less pay."

"I allow yer hev hed easy times afore, then," retorted Aunt Ri, good naturedly satirical, "ef yeow air plum tired doin' thet!" and she took her leave, not a whit clearer in her mind as to the real nature and function of the Indian Agency than she was in the beginning. 
Through all of Ramona's journey home, she seemed to herself to be in a dream. Her baby in her arms; the faithful creatures Baba and Benito gaily trotting along; at a pace so swift that the carriage seemed gliding; Felipe by her side,- - the dear Felipe,- - his eyes wearing the same bright and loving look as of old,- - what strange thing was it,

5 which had happened to her, to make it all seem unreal? Even the little one in her arms,she too seemed unreal! Ramona did not know it, but her nerves were still partially paralyzed; nature sends merciful anesthetics in the shocks which about kill us. In the very sharpness of the blow, something lies its own healing. It would be long before Ramona would fully realize that Alessandro was dead. Her worst anguish was yet to come.

Felipe did not know and could not have understood this; and it was with a marvelling gratitude that he saw Ramona, day after day, placid, always ready with a smile when he spoke to her. Her gratitude for each thoughtfulness of his, smote him like a reproach; all the more that he knew her gentle heart had never held a thought of reproach in it, towards him. "Grateful to me!" he thought, "to me, who might have spared her all

15 this woe, if I had been strong!"

Never would Felipe forgive himself, no, not to the day of his death. His whole life should be devoted to her and her child, but what a pitiful thing was that to render!

As they drew near home, he saw Ramona often try to conceal from him that she had shed tears. At last he said to her,

"Dearest Ramona, do not fear to weep before me. I would not be any constraint on you. It is better for you to let the tears come freely, my sister. They are healing to wounds."

"I do not think so, Felipe," replied Ramona. "Tears are only selfish, and weak. They are like a cry because we are hurt. It is not possible always to hold them back, but I am ashamed when I have wept; and think also that I have sinned; because I have given a sad sight to others. Father Salvierderra always said that it was a duty to look happy, no matter how much we might be suffering."

"That is more than human power can do!" said Felipe.

"I think not," replied Ramona. "If it were, Father Salvierderra would not have

30 commanded it. And do you not recollect Felipe what a smile his face always wore? and his heart had been broken for many many years before he died. Alone, in the night when he prayed, he used to weep from the great wrestling he had with God, he told me, but we never saw him except with a smile.

When one thinks, in the wilderness, alone, Felipe, many things become clear. I

35 have been learning all these years, in the wilderness, as if I had had a teacher. Sometimes I almost thought that the spirit of Father Saliverderra was by my side, putting thoughts into my mind.

I hope I can tell them to my child, when she is old enough. She will understand them quicker than I did, for she has Alessandro's soul. You can see that, by her eyes; and 
all these things of which I speak, were in his heart, from his childhood. They belong to the air, and the sky, and the sun, and all trees know them."

When Ramona spoke thus of Alessandro, Felipe marvelled in silence. He himself had been afraid to mention Alessandro's name; but Ramona spoke it, as if he were yet by

5 her side. Felipe could not fathom this. There were to be many things yet, which Felipe could not fathom in this lovely sorrowing sunny sister of his.

When they reached the house, the servants who had been on the watch for days, were all gathered in the court yard, old Marda, and Juan Can, heading the group; only two absent, - Margarita and Luigo. They had been married, some months before, and were living at the Ortega's ranch, where Luigo, to Juan Can's scornful amusement, had been made head shepherd.

On all sides were beaming faces, smiles, and glad cries of greeting. Underneath these were affectionate hearts quaking with fear lest the home coming be but a sad one, after all. Vaguely they knew a little of what their dear Señorita had been through since she left them; it seemed that she must be sadly altered by so much sorrow; and that it would be terrible to her to come back to the place so full of painful associations; "and the Señora gone too!" said one of the outdoor hands, as they were talking it over, "It's not the same place at all, that it was when the Señora was here!"

"Humph!" muttered Juan Can, more consequential and overbearing than ever, for

20 this year of absolute control of the estate, "Humph! That's all you know. A good thing the Señora died, when she did, I can tell you! We'd never have seen the Señorita back here, else; I can tell you that my man! And for my part, I'd much rather be under Señor Felipe and the Señorita, than under the Señora, peace to her ashes! She had her day. They can have theirs now."

When these loving and excited retainers, saw Ramona, pale, but with her own old smile on her face, coming towards them with her babe in her arms, they broke into wild cheering; and there was not a dry eye in the group.

Singling out old Marda, by a glance, Ramona held out the baby, towards her, and said, in her old gentle, affectionate voice, "I am sure you will love my baby, Marda!"

"Señorita! Señorita! God bless you Señorita!" they cried, and closed up their ranks around the baby, touching her, praising her, handing her from one to another.

Ramona stood for a few seconds watching them; then she said, "Give her to me, Marda. I will myself carry her into the house," and she moved toward the inner door.

"This way! Dear! This way," cried Felipe; “it is Father Salvierderra's room I

35 ordered to be prepared for you, because it is so sunny for the baby!"

"Thanks kind Felipe!" cried Ramona, and her eyes said more than her words. She knew he had divined the one thing she had most dreaded in returning,- - the crossing again the threshold of her own room. It would be long now before she would enter that room. Perhaps she would never enter it. How tender and wise of Felipe! 
Yes! Felipe was both tender and wise, now. How long would the wisdom hold the tenderness in leash, as he day after day looked when the face of this beautiful woman,so much more beautiful now than she had been before her marriage, that Felipe sometimes, as he gazed at her, thought her changed even in feature. But in this very change, lay a spell which would for a long time surround her, and set her as apart from lover's thoughts as if she were guarded by a cordon of viewless spirits. There was a rapt look of holy communion on her face which made itself felt by the dullest perception, and sometimes overawed even where it attracted. It was the same thing which Aunt Ri, had felt, and formulated in her own humorous fashion: but old Marda, put it better, when one day, in reply to a half terrified low whispered suggestion of Juan Can's, to the effect that it was "a great pity the Señor Felipe hadn't married the Señorita, years ago,- - What if he were to do it yet?" she said, also under her breath, "it is my opinion he'd as soon think of Saint Catharine herself! Not but that it would be a great thing if it could be!"

The thing that the Señora had imaged to herself so often, had come about,- the presence of a little child, in her house, on the verandah, in the garden, everywhere; the sunny joyous blest presence. But how differently had it come! Not Felipe's child, as she proudly had pictured; but the child of Ramona; the friendless banished Ramona returned now, into full honor and peace, as the daughter of the house,--Ramona, widow of Alesssandro. If the child had been Felipe's own, he could not have felt for it a greater

20 love. From the first, the little thing had clung to him, as only second to her mother. She slept hours in his arms, one little hand hid in his dark beard, close to his lips, and kissed again and again when no one saw. Next to Ramona herself in Felipe's heart came Ramona's child; and on the child he could lavish the fondness he felt that he could never dare to show to the mother. Month by month, it grew clearer to Felipe that the main

25 springs of Ramona's life, were no longer of this earth; that she walked as one in constant fellowship with one unseen. Her frequent and calm mention of Alessandro did not deceive him. It did not mean a lessening grief: it meant an unchanged relation.

One thing weighed heavily on Felipe's mind, - the concealed treasure. A sense of humiliation withheld him, day after day from speaking of it. But he could have no peace until Ramona knew it. Each hour that he delayed the revelation he felt himself almost as guilty as he had held his mother to be. At last he spoke. He had not said many words, before Ramona interrupted him,

"Oh yes!" she said, "I knew about those things; your mother told me. When we were in such trouble I used to wish sometimes we could have had a few of the jewels. But

35 they were all given to the Church. That was what the Señora Ortegna said must be done with them if I married against your mother's wishes."

It was with a shame stricken voice that Felipe replied, "Dear Ramona, they were not given to the Church. You know Father Salvierderra died; and I suppose, my mother did not know what to do with them. She told me about them, just as she was dying."

"But why did you not give them to the Church dear?" asked Ramona, simply. 
"Why?" cried Felipe, "because I hold them to be yours, and yours only. I would never have given them to the Church, until I had sure proof that you were dead and had left no children."

Ramona's eyes were fixed earnestly on Felipe's face.

"You haven't read the Señora Ortegna's letter," she said.

"Yes I have;" he replied, "every word of it."

"But that said, I was not to have any of the things if I married against the Señora Moreno's will."

Felipe groaned. Had his mother lied? "No dear," he said, "that was not the word. It was if you married unworthily."

Ramona reflected. "I never recollected the words," she said. "I was too frightened; but I thought that was what it meant. I did not marry unworthily. Do you feel sure Felipe, that it would be honest for me to take them for my child?"

"Perfectly," said Felipe.

"Do you think Father Salvierderra would say I ought to keep them?"

"I am sure of it dear."

"I will think about it, Felipe. I cannot decide hastily. Your mother did not think I had any right to them, if I married Alessandro. That was why she showed them to me. I never knew of them till then. I took one thing,- - a handkerchief of my father's. I was very glad to have it, but it got lost, when we went from San Pasquale. Alessandro rode back a half day's journey to find it for me; but it had blown away. I grieved sorely for it."

The next day, Ramona said to Felipe,

"Dear Felipe, I have thought it all over about those jewels. I believe it will be right for my daughter to have them. Can there be some kind of paper, written for me to 25 sign, to say that if she dies, they are all to be given to the Church,- - to Father Salvierderra's College, in Santa Barbara? That is where I would rather have them go." "Yes dear," said Felipe, "and then we will put them in some safer place; I will take them to Los Angeles when I go. It is wonderful no one has stolen them all these years."

And so, a second time the Ortegna jewels were passed on, by a written bequest, into the keeping of that mysterious certain, uncertain thing we call the future, and delude ourselves with the fancy that we can have much to do with its shaping.

Life ran smoothly in the Moreno household,- - smoothly to the eye; nothing could be more peaceful fairer to see, than the routine of its days, with the simple pleasures, light 35 tasks, and easy diligence of all. Summer and winter were alike sunny — and had each its own joys. There was not an antagonistic or jarring element; and, flitting back and forth, from verandah, to verandah, garden to garden, room to room, equally at home, and equally welcome everywhere, went perpetually, running, frisking laughing rejoicing, the little child, that had so strangely drifted into this happy shelter,- - the little Ramona. As unconscious of aught sad or fateful in her destiny, as the blossoms with which it was her 
delight to play, she sometimes seemed to her mother to have been from the first in some mysterious way disconnected from it, removed, set free from all that could ever by any possibility link her to sorrow.

Ramona herself bore no impress of sorrow; rather her face had now an added

5 radiance. There had been a period soon after her return, when she felt that she for the first time waked to the realization of her bereavement; when every sight sound, and place seemed to cry out, mocking her with the name and the memory of Alessandro; but she wrestled with this absorbing grief as with a sin; setting her will steadfastly to the purposes of each day's duty, and most of all to the duty of joyfulness. She repeated to herself Father Salvierderra's sayings, till she more than knew them by heart; and she spent long hours of the night in prayer as it had been his wont to do.

No one but Felipe dreamed of these vigils and wrestlings. He knew them; and he knew too when they ceased, and the new light of a new victory diffused itself over Ramona's face: but neither did the first dishearten, nor the latter encourage him. Felipe was a clearer sighted lover now than he had been in his earlier youth. He knew that into the world when Ramona really lived, he did not so much as enter; yet her every act word look was full of loving thoughtfulness of and for him, loving happiness in his companionship. And while this was so, all Felipe's unrest could not make him unhappy.

There were other causes entering into this unrest besides his yearning desire to

20 win Ramona for his wife. Year by year the conditions of life in California were growing more distasteful to him. The methods, aims, standards of the fast incoming Americans were, to him, odious. Their boasted successes, the crowding of colonies, schemes of settlement, and development, - all were disagreeable, and irritating. This passion for money, and reckless spending of it, the great fortunes made in one hour, thrown away in

25 another, savored to Felipe's mind, more of brigandage and gambling, than of the occupations of gentlemen. He loathed them. Life under the new government grew more and more intolerable to him; both his hereditary instincts and prejudices, and his temperament revolted.

He found himself more and more alone in the country. Even the Spanish tongue

30 was less and less spoken. He was beginning to yearn for Mexico,- - for Mexico which he had never seen, yet yearned for, like an exile. There he might yet live among men of his own race and degree, and of congenial beliefs and occupations. Whenever he thought of this change, always came the quick memory of Ramona. Would she be willing to go? Could it be that she felt a bond to this land in which she had known nothing but suffering?

At last he asked her. To his unutterable surprise, Ramona cried,

"Felipe! The Saints be praised! I should never have told you. I did not think that you could wish to leave this estate. But my most beautiful dream for Ramona would be that she should grow up in Mexico." 
And as she spoke, Felipe understood by a lightning intuition, and wondered that he had not foreknown it, that she would spare her daughter, the burden she had gladly, heroically borne, herself, in the bond of race.

The question was settled. With gladness of heart almost more than he could have

5 believed possible, Felipe at once communicated with some rich American proprietors who had desired to buy the Moreno estate. Land in the valley had so greatly advanced in value, that the sum he received for it was larger than he had dared to hope; was ample for the realization of all his plans for the new life in Mexico. From the hour that this was determined, and the time for their sailing fixed, a new expression came into Ramona's face. Her imagination was kindled. An untried future beckoned, - a future which she would embrace and conquer for her daughter. Felipe saw the look, felt the change, and for the first time hoped. It would be a new world, a new life; why not a new love? She could not always be blind to his devotion; and when she saw it, could she refuse to reward it? He would be very patient and wait long, he thought. Surely since he had been patient so long without hope, he could be still more patient, now that hope had dawned. But patience is not hope's province, in breasts of lovers. From the day when Felipe first thought to himself,

"She will yet be mine," it grew harder and not easier, for him to refrain from pouring out his love in words. Her tender sisterliness which had been such balm and

20 comfort to him, grew at times intolerable; and again and again her gentle spirit was deeply disquieted with the fear that she had displeased him, so strangely did he conduct himself.

He had resolved that nothing should tempt him to disclose to her, his passion, and its dreams, until they had reached their new home. But there came a moment which 25 mastered him, and he spoke.

It was in Monterey. They were to sail on the morrow, and had been on board the ship to complete the last arrangements. They were rowed back to shore in a little boat. A full moon shone. Ramona sat bareheaded in the end of the boat, and the silver radiance from the water seemed to float up around her, and invest her as with a myriad halos.

30 Felipe gazed at her, till his senses swam; and when on stepping from the boat, she put her hand in his, and said as she had said hundreds of times before,"

"Dear Felipe! How good you are," he clasped her hands wildly, and cried, "Ramona! My love, oh, can you not love me!" The moonlight was bright as day. They were alone on the shore. Ramona gazed at him for one second, in surprise; only 35 for a second; then she knew all.

"Felipe! My brother!" she cried, and stretched out her hands as if in warning.

"No! I am not your brother," he cried. "I will not be your brother! I would rather die!"“Felipe!" cried Ramona again. This time her voice recalled him to himself. It was a voice of terror, and of pain. 
"Forgive me, my sweet one," he exclaimed. "I will never say it again. But I have loved you so long,--so long."

Ramona's head had fallen forward on her breast; her eyes fixed on the shining sands; the waves rose and fell rose and fell at her feet gently as sighs. A great revelation

5 had come to Ramona. In this supreme moment of Felipe's abandonment of all disguises, she saw his whole past life in a new life. Remorse smote her.

"Dear Felipe," she said, clasping her hands, "I have been very selfish. I did not know-"

"Of course you did not love," said Felipe- - "how could you! But I have never

10 loved anyone else. I have always loved you. Can you not learn to love me? I did not mean to tell you for a long time yet. But now I have spoken; I cannot hide it any more."

Ramona drew nearer to him - still with her hands clasped,

"I have always loved you," she said. "I love no other living man;-_but Felipe,_-, her voice sank to a solemn whisper,- “do you not know Felipe that part of me is dead,15 dead? can never live again?

You could not want me for your wife Felipe, when part of me is dead?"

Felipe threw his arms around her. He was beside himself with joy.

"You would not say that if you did not think that you could be my wife," he cried, "Only give yourself to me, my love, I care not whether you call yourself dead or alive!"

20 Ramona stood quietly in his arms. Ah well for Felipe that he did not know, never could know the Ramona that Alessandro had known. This gentle faithful grateful Ramona, asking herself fervently now if she would do her brother a wrong, yielding up to him what seemed to her, only the broken fragment of a life; weighing his words not in the light of passion, but calmest most unselfish affection,--Ah how unlike was she to that

25 Ramona, who flung herself on Alessandro's breast crying, "Take me with you! I would rather die, than have you leave me!"

Ramona had spoken truth. Part of her was dead. But Ramona saw now with infallible intuition, that even as she had loved Alessandro, so Felipe loved her. Could she refuse to give Felipe happiness, when he had saved her, saved her child? What else now remained for them, these words having been spoken?

"I will be your wife, dear Felipe," she said, speaking solemnly slowly, "if you are sure it will make you happy, and if you think it is right."

"Right!" ejaculated Felipe, mad with the joy unlooked for so soon. "Nothing else would be right! My Ramona, I will love you so you will forget you ever said that part of 35 you was dead!"

A strange look which startled Felipe swept across Ramona's face; it might have been a moonbeam. It passed. Felipe never saw it again.

General Moreno's name was still held in warm remembrance in the city of Mexico, and Felipe found himself at once among friends. On the day after their arrival, 40 he and Ramona were married in the cathedral, old Marda, and Juan Can, with his 
crutches, kneeling in proud joy behind them. The story of the romance of their lives, being widely rumored, greatly enhanced the interest with which they were welcomed, the beautiful young Señora Moreno was the theme of the city, and Felipe's bosom thrilled with pride to see the gentle dignity of demeanor, by which she was distinguished in all

5 assemblages. It was indeed a new world, a new life. Ramona might well doubt her own identity. But undying memories stood like sentinels in her breast. When the notes of doves calling to each other fell on her ear, her eyes sought the sky, and she heard a voice saying "Majella." This was the only secret her loyal loving heart had kept from Felipe. A loyal loving heart indeed it was; loyal, loving, serene; few husbands so blest, as was the

10 Señor Felipe Moreno. Sons and daughters came to bear his name. The daughters were all beautiful; but the most beautiful of them all, and, it was said, the most beloved by both father and mother, was the eldest one; the one who bore the mother's name and was only step daughter to the Señor;- - Ramona,- Ramona, daughter of Alessandro the Indian 


\section{Historical Collation}

All of the substantive and accidental variants between the manuscript, Christian Union, and Roberts Brothers first edition are listed below, by chapter. The first number for each entry refers to the page number; the second refers to the line number. An asterisk preceding the page-line number indicates that there is a textual note concerning that reading. The textual notes themselves are located at the end of the collation. Each note is listed by page-line number, followed by the reading accepted for the critical edition. A chart of the variants for paragraph breaks (see the textual commentary for a discussion on paragraph breaks) follows the textual notes.

For the textual variants, the reading in front of the bracket is the one accepted for the critical edition. The two readings following the bracket, separated by a semicolon, are the rejected readings. A tilde indicates a word that is the same between readings. A caret means that a punctuation mark in an accepted reading is missing from a rejected reading. Omit means that a word does not appear in a certain source.

In Chapter 1, Jackson has several words that are hyphenated because a new line begins in the middle of the word. Whether or not Jackson intended to hyphenate these words cannot be told for sure; I list these hyphenations after the chapter one variants. Chapter 26 had no line-end hyphenations in the manuscript.

Throughout, the following sigla are used:

M A reading from Jackson's manuscript

CU A reading from the Christian Union

RB1 A reading from the Roberts Brothers first edition

\section{Chapter 1}

1.1: time,] $\mathbf{M} ; \sim$ RB1, CU

1.2: Señora ] CU, RB1 ; Senora $M$

*1.2: fates] M; Fates CU, RB1

1.3: Señora's ] CU, RB1; Senora's M

1.3: son;] M ; son, CU, RB1

1.5: Señora ] CU, RB1 ; Senora M

1.5: always,] CU, RB1; always $\mathbf{M}$

1.5: Señor ] CU, RB1; Senor M

1.5: Señor ] CU, RB1; Senor M

1.6: Señor ] CU, RB1 ; Senor M

1.8: truth] $\mathbf{M}$; truth, CU, RB1

*1.8: Señora ] CU, RB1 ; Senora M

*1.8: Señora,] CU, RB1; Senora 、M 
1.9: sheep pastures] $\mathbf{M}$; sheep-pastures $\mathbf{C U}, \mathbf{R B 1}$

1.10: artichoke patch] $\mathbf{M}$; artichoke-patch CU, RB1

*1.10: patch; ] CU, RB1 ; . $\mathbf{M}$

1.10: Señora ] CU, RB1 ; Senora $\mathbf{M}$

1.11: Señora ] CU, RB1 ; Senora M

1.11: Moreno,-—] RB1 ; : ; M ; - CU

1.12: exceptionally ] M, RB1 ; especially $\mathbf{C U}$

1.14: romance, ] M, RB1 ; romance $\mathbf{C U}$

1.15: new ] M ; New CU, RB1

1.15: Spain, ] M, RB1 ; Spain; CU

1.15: Ocean,- - ] M, RB1 ; Ocean- CU

1.16: Señora ] CU, RB1 ; Senora $\mathbf{M}$

1.18: did,-—] RB1 ; ; M ; - CU

1.19: quiet ] M ; , CU, RB1

1.19: reserved ] $\mathbf{M}$; , CU, RB1

1.20: imperious, ] $\mathbf{M}$; imperious $\mathbf{C U}, \mathbf{R B 1}$

1.21: stress;- ] M ; stress; CU, RB1

1.21: turns ] $\mathbf{M} ; \sim$, CU, RB1

1.22: appeared ] M ; , CU, RB1

1.22: Señora ] CU, RB1 ; Senora $\mathbf{M}$

1.23: about, ] M, RB1 ; about CU

1.24: dark ] M, RB1 ; omit $\mathbf{C U}$

1.25: sad ] M ; , CU, RB1

1.25: spiritual minded ] M ; spiritual-minded CU, RB1

1.30: mind: ] M, RB1 ; ; CU

1.31: when ] M ; , CU, RB1

1.31: known, ] $\mathbf{M}$; . CU, RB1

1.32: Señora ] CU, RB1 ; Senora $\mathbf{M}$

1.32: exactly, ] M ; . CU, RB1

*1.35: been, ] CU, RB1 ; . $\mathbf{M}$

1.36: Can, ] M ; CU, RB1

*1.37: discussions ] CU, RB1 ; talks M

1.38: Señora's ] CU, RB1 ; Senora's M

1.39: Señor ] CU, RB1 ; Senor M

1.40: bed; ] M ; , CU, RB1

1.40: flock, ] M ; , CU, RB1

*2.1: coast ] CU, RB1 ; , M

2.2: morning, ] $\mathbf{M} ; \sim-\mathbf{C U} ; \sim,-\mathbf{R B 1}$

2.3: rest, ] M ; ; CU, RB1

2.3: Señor ] CU, RB1; Senor M

2.4: packing bag ] M ; packing-bag CU, RB1

2.4: Señor ] CU, RB1 ; Senor M

2.5: Señora ] CU, RB1 ; Senora $\mathbf{M}$

2.6: presently; ] M ; , CU, RB1

2.6: Señora ] CU, RB1 ; Senora $M$

2.7: Indians; ] M ; . CU, RB1 
2.7: of ] $\mathbf{M}$; Of CU, RB1

2.7: course, ] CU, RB1; . M

2.7: Mexicans ] $\mathbf{M} ; \sim, \mathbf{C U}, \mathbf{R B 1}$

2.8: Indians, $-\mathbf{R B 1} ; \sim, \mathbf{M} ; \sim-\mathbf{C U}$

2.9: breath; ] M ; . CU, RB1

2.10: Señora ] CU, RB1 ; Senora $M$

2.11: this ] M, RB1 ; the $\mathbf{C U}$

*2.13: tones! ] CU, RB1 ; tones: $\mathbf{M}$

*2.14-15: with a look to the fathoming of which he was as unequal as one of his own sheep would have been ] CU, RB1; with a look which he was as unequal as one of his own sheep to fathoming $\mathbf{M}$

2.15: instantly, ] $\mathbf{M} ; \sim$ CU, RB1

2.16: pardon ] M ; , CU, RB1

2.16: Señora ] CU, RB1 ; Senora $M$

2.17: Oh ] M ; , CU, RB1

2.17: Señora ] CU, RB1 ; Senora $M$

2.18: gentleness, ] M ; ; CU, RB1

2.20: Juan; ] CU, RB1 ; , M

2.20: Señor ] CU, RB1 ; Senor M

2.22: Señor ] CU, RB1; Senor M

*2.24: week or two, ] CU, RB1; week, or two M

2.25: think ] M ; , CU, RB1

2.26: wool crop ] M ; wool-crop CU, RB1

2.27: sheep's ] CU, RB1 ; sheeps M

2.28: Señora ] CU, RB1 ; Senora $M$

2.28: Juan; ] CU, RB1 ; . M

2.30: year's ] CU, RB1 ; years $\mathbf{M}$

2.32: Señora ] CU, RB1 ; Senora M

2.32: smiled ] $\mathbf{M}$; , CU, RB1

2.35: instances, ] M ; CU, RB1

2.35: Señora's ] CU, RB1 ; Senoras $\mathbf{M}$

2.36: clashed, ] M ; C CU, RB1

2.37: Señor ] CU, RB1; Senor M

2.37: Señora's ] CU, RB1 ; Senoras $\mathbf{M}$

2.37: proceeded: ] CU, RB1 ; . M

2.38: Señor ] CU, RB1 ; Senor M

2.38: together, ] M ; ; CU, RB1

*2.39: it, ] CU, RB1 ; . M

3.5: brief, ] $\mathbf{M} \sim \mathbf{C U}, \mathbf{R B 1}$

3.5: Señora's ] CU, RB1 ; Senora's M

3.7: turned ] M, RB1 ; , CU

3.8: colley, ] CU, RB1 ; M

3.9: Down, ] CU, RB1 ; ! M

*3.9: Capitan, ] CU, RB1 ; . M

3.9: tone, ] CU, RB1 ; . M 
3.9: him, ] M ; ; CU, RB1

*3.10: noise, ] M ; CU, RB1

3.10: Señora ] CU, RB1 ; Senora $M$

3.11: Señora ] CU, RB1 ; Senora M

*3.11: Senora, ] M ; Señora C CU, RB1

3.13: comes ] M; , CU, RB1

3.14: fellow being ] $\mathbf{M}$; fellow-being CU, RB1

3.15: Señor ] CU, RB1 ; Senor M

*3.15: world ] CU, RB1 ; , M

*3.16: day; ] CU, RB1 ; , M

*3.17: another? ] CU, RB1 ; . M

3.18: Señora ] CU, RB1 ; Senora M

3.20: Señora ] CU, RB1 ; Senora $M$

3.24: prayers! ] CU, RB1 ; . M

3.25: Heaven ] M ; heaven CU, RB1

3.25: Señora'll ] CU, RB1; Senora'll M

3.26: what's ] CU, RB1 ; whats $\mathbf{M}$

3.26: heart ] M ; , CU, RB1

3.27: know. ] M, RB1 ; ? CU

3.28: died,-— ] RB1 ; ; M ; - CU

3.28: day! ] CU, RB1 ; . M

3.29: Father, ] M ; ; CU, RB1

3.30: it's ] CU, RB1 ; its $\mathbf{M}$

3.30: them, ] M, RB1 ; , CU

3.30: they've ] CU, RB1 ; theyve $\mathbf{M}$

3.30: Señor ] CU, RB1 ; Senor M

3.32: irritation, ] M, RB1 ; $\mathbf{C U}$

3.34: Salvierderra ] M ; , CU, RB1

3.35: priest,-— ] RB1; , M ; , , - CU

3.35: tongue, ] M ; CU, RB1

3.36: himself,-— ] RB1 ; , M ; , 一 CU

3.37: everything ] $\mathbf{M}$; , CU, RB1

3.39: it's ] CU, RB1 ; its M

3.39: child's ] CU, RB1 ; childs $M$

4.1: and ] M, RB1 ; , $\mathbf{C U}$

4.2: verandah ] $\mathbf{M}$; veranda $\mathbf{C U}, \mathbf{R B 1}$

4.2: South ] M ; south CU, RB1

4.3: bench, ] M ; CU, RB1

4.4: half way ] M ; half-way CU, RB1

4.4: court yard ] M ; court-yard CU, RB1

4.6: purpose, ] M ; , CU, RB1

4.6: sheep, ] M ; ; CU, RB1

4.6: and ] $\mathrm{M} ; \sim, \mathbf{C U}, \mathbf{R B 1}$

4.8: master's ] CU, RB1 ; masters $\mathbf{M}$

4.9: month ] M ; , CU, RB1 
4.9: Today ] $\mathbf{M}$; To-day CU, RB1

4.10: twenty fifth ] $\mathbf{M} ; 25^{\text {th }} \mathbf{C U}, \mathbf{R B 1}$

4.11: here; ] M ; . CU, RB1

4.11: chapel; ] M ; , CU, RB1

4.11: night, ] M ; , CU, RB1

4.11: vespers, ] M ; ; CU, RB1

4.12: lose, ] $\mathbf{M}$; . CU, RB1

4.13: Señor ] CU, RB1; Senor M

4.16: Señora's ] CU, RB1 ; Senora's M

4.17: house ] $\mathbf{M}$; , CU, RB1

4.17: to; ] M ; : CU, RB1

4.19: Yes! ] M ; ; CU, RB1

4.19: Señor ] CU, RB1; Senor M

4.20: two ] M ; , CU, RB1

*4.20: Ha, it ] M ; ha! It CU, RB1

4.25: Señor ] CU, RB1; Senor M

4.25: Felipe's ] CU, RB1; Felipes M

4.26: sheep shearing ] M ; sheep-shearing CU, RB1

4.26: day,- ] RB1 ; ; $\mathbf{M}$; - CU

4.27: all; ] M ; . CU, RB1

4.28: white washed ] $\mathbf{M}$; whitewashed $\mathbf{C U}, \mathbf{R B 1}$

4.29: omit veranda ] CU, RB1 ; stone paved verandah $\mathbf{M}$

4.29: verandah ] $\mathbf{M}$; veranda $\mathbf{C U}, \mathbf{R B 1}$

4.29: firm wedged ] M, RB1 ; firm-wedged $\mathbf{C U}$

4.31: Señora ] CU, RB1 ; Senora $\mathbf{M}$

4.31: Moreno's ] CU, RB1; Morenos M

4.33: Juan's ] M ; Juans CU, RB1

4.34: trousers ] $\mathbf{M} ; \sim, \mathbf{C U}, \mathbf{R B 1}$

4.34: unreproved, ] $\mathbf{M} ; \sim$, CU, RB1

4.36: good natured ] $\mathbf{M}$; good-natured CU, RB1

4.36: today ] $\mathbf{M}$; to-day $\mathbf{C U}, \mathbf{R B 1}$

*4.36: today, ] M ; ? CU, RB1

4.36: Margarita ] M ; , CU, RB1

4.38: wrinkled, ] M ; CU, RB1

5.1-2: under shepherds ] $\mathbf{M}$; under-shepherds CU, RB1

5.3: Señorita ] CU, RB1 ; Senorita $M$

5.5: He! ] M ; he! CU, RB1

5.5: Señorita ] CU, RB1 ; Senorita $M$

5.6: Señor ] CU, RB1 ; Senor M

5.6: betters,"] M ; ;" CU, RB1

5.7: over clean ] M ; over-clean CU, RB1

5.7: head, ] M, RB1 ; CU

5.9: sleight of hand ] $\mathbf{M}$; sleight-of-hand $\mathbf{C U}, \mathbf{R B 1}$

5.9: hand, ] M ; . CU, RB1

5.9: cocks, ] CU, RB1 ; . M

5.11: bird shot ] $\mathbf{M}$; bird-shot CU, RB1 
5.11: running, - ] RB1 ; , M ; - CU

5.11: Anita, ] M ; C CU, RB1

5.12: Maria ] M ; , CU, RB1

5.12: place, ] M ; , CU, RB1

5.13: bride;-— ] M ; ; CU, RB1

5.13: daughters ] M ; , CU, RB1

5.13: Rosa, ] M ; CU, RB1

*5.14: mother; ] CU, RB1 ; , M

5.14: Juanita ] M ; , CU, RB1

5.15: Señora ] CU, RB1 ; Senora $M$

5.15: history, ] M ; CU, RB1

5.16: she ] M ; , CU, RB1

5.16: thing $\mathbf{M}] \sim$ ! CU ] , RB1

5.16: nothing ] $\mathbf{M} ; \sim, \mathbf{C U}, \mathbf{R B 1}$

5.18: omitted, ] M ; CU, RB1

5.19: estate, ] M ; ; CU, RB1

5.19: house, ] M, RB ; CU

5.20: pod; ] M ; , CU, RB1

*5.20: (tons of them, one would think) ] CU, RB1 ; (one would think), (tons of them;) $\mathbf{M}$

5.21: Señora's ] CU, RB1 ; Senoras $M$

*5.22: kitchen ] $\mathbf{M} ; \sim, \mathbf{C U}$,

*5.23: cousins, ] CU, RB1; . M

*5.23: widows, ] M ; CU, RB1

*5.23: daughters ] $\mathbf{M} ; \sim$, CU, RB1

*5.24: cousins, ] CU, RB1; . M

5.24: sons ] $\mathbf{M} ; \sim, \mathbf{C U}, \mathbf{R B 1}$

*5.24: stopping, ] $\mathbf{M} \sim, \mathbf{C U}, \mathbf{R B 1}$

5.25: pay roll ] $\mathbf{M}$; pay-roll CU, RB1

5.25: Señor ] CU, RB1 ; Senor $\mathbf{M}$

5.26: roof ] $\mathrm{M} ; \sim, \mathbf{C U}, \mathbf{R B 1}$

5.28: disgraceful ] M, RB1 ; , CU

*5.29: Senora, ] M ; , CU, RB1

*5.29: Señora ] CU, RB1 ; Senora M

5.29: place, a ] M ; place. A CU, RB1

5.31: freehanded ] M ; free-handed CU, RB1

5.32: men ] M ; , CU, RB1

5.32: children ] M ; , CU, RB1

5.33: day, ] M ; ; CU, RB1

*5.35: which ] M, CU ; , RB1

5.35: Juan's ] CU, RB1 ; Juans $\mathbf{M}$

5.36: "good ] M ; “Good CU, RB1

5.36: Heavens ] $\mathbf{M}$; heavens $\mathbf{C U}, \mathbf{R B 1}$

5.36: Heavens, ] M ; ! CU; , RB1

5.36: women ] M ; , CU, RB1

5.36: children ] M ; , CU, RB1 
5.37: house!",-—] M ; ? CU ; ! RB1

5.37: Señora's ] CU, RB1 ; Senoras $\mathbf{M}$

5.37: thought ] M ; , CU, RB1

5.37: was, ] CU, RB1 ; . M

5.38: things; how ] M ; things! How CU, RB1

*5.39: hard, ] M ; . CU, RB1

5.39: her! ] M, CU ; . RB1

5.39: and ] $\mathbf{M}$; And CU, RB1

5.40: house, ] M ; CU, RB1

*6.1: heart; ] CU, RB1 ; , M

6.2: she ] CU, RB1 ; the Señora $\mathbf{M}$

6.2: second,-—] RB1; ; M ; - CU

6.2: however, ] M ; ; CU, RB1

6.5: son. ] M ; , CU, RB1

6.6: "Oh ] M , CU; “'O RB1

6.6: son; ] M ; ! CU, RB1

6.6: in her ] M, RB1 ; to her CU

6.6: Saints ] M ; saints CU, RB1

6.10: born, ] M, RB1 ; CU

6.10: stature ] M ; , CU, RB1

*6.13: true, ] CU, RB1 ; 、 $\mathbf{M}$

*6.14: not, ] CU, RB1 ; - M

*6.14: Felipe ] CU, RB1; , M

6.15: celebration, ] $\mathbf{M} ; \sim$, CU, RB1

6.15: procession ] $\mathbf{M}$; , CU, RB1

6.15: put on a ] M, RB1 ; put on the CU

6.15: gold wrought ] $\mathbf{M}$; gold-wrought $\mathbf{C U}, \mathbf{R B 1}$

*6.16: mantle, ] CU, RB1 ; . M

6.17: gold and silver ] M ; gold-and-silver CU, RB1

6.17: trimmed ] M, RB1; omit $\mathbf{C U}$

6.17: worn, ] M ; CU, RB1

6.18: Señora ] CU, RB1 ; Senora $M$

6.18: him,- ] RB1 ; ; M ; - CU

6.19: dark bearded ] M ; dark-bearded CU, RB1

6.19: man, ] M, RB1 ; , CU

6.20: distress ] M ; , CU, RB1

6.22: them, ] M ; , CU, RB1

6.23: parade, ] M ; ; CU, RB1

6.25: faintly cried ] M, RB1; omit cried $\mathbf{C U}$

6.25: Señora ] CU, RB1 ; Senora M

6.26: and ] M, RB1 ; , CU

6.26-27: sword belt ] M ; sword-belt CU, RB1

6.27: belt ] M ; , CU, RB1

*6.27: times- ] CU, RB1 ; , 一 M

6.27: un-kissed-] CU, RB1 ; , - M 
6.27: buckled, ] M, RB1 ;

6.28: fare well ] M ; farewell CU, RB1

6.29: tears, - ] RB1; , M ; - CU

6.30: officer, ] M ; CU, RB1

6.31: like, ] M ; CU, RB1

*6.32: gallopped ] M ; galloped CU, RB1

6.33: Then, ] M ; , CU, RB1

6.33: face, ] M ; CU, RB1

6.36: comfort, ] M ; . CU, RB1

6.39: sheep shearing ] M ; sheep-shearing CU, RB1

6.40: Señor ] CU, RB1 ; Senor M

6.40: non appearance ] $\mathbf{M}$; non-appearance CU, RB1

7.1: more, ] M ; CU, RB1

*7.1: perspicacity ] M ; , CU, RB1

7.1: over-heard ] M ; over heard CU, RB1

7.2: Señora ] CU, RB1 ; Senora $\mathbf{M}$

7.2: son, ] M, RB1 ; , CU

7.2: time, ] M ; . CU, RB1

7.2: he, ] M ; CU, RB1

7.3: verandah ] $\mathbf{M}$; veranda $\mathbf{C U}, \mathbf{R B 1}$

7.3: verandah ] $\mathbf{M} ; \sim, \mathbf{C U}, \mathbf{R B 1}$

7.6: Can, ] M ; . CU, RB1

7.6: sheep shearing ] $\mathbf{M}$; sheep-shearing CU, RB1

7.6: Señora ] CU, RB1 ; Senora $\mathbf{M}$

7.7: Felipe, — ] RB1 ; , M ; - CU

7.8: him, ] M ; , CU, RB1

7.10: little ] M ; , CU, RB1

7.10: fancy ] $\mathbf{M}$; , CU, RB1

7.11: Now, ] M ; , CU, RB1

*7.13: Felipe ] CU, RB1 ; , M

7.13: mother, ] M ; , CU, RB1

7.14: affection, ] M ; , CU, RB1

*7.15: Indeed, ] CU, RB1 ; . M

7.16: Saints ] M ; saints CU, RB1

7.16: Saints, ] M ; ; CU, RB1

7.16: mother's ] RB1

7.18: me ] M ; , CU, RB1

7.19: mother, ] M ; ; CU, RB1

7.20: proud; ] $\mathbf{M}$; , CU, RB1

7.20: God, ] M ; god . CU, RB1

7.21: me, ] M ; C CU, RB1

7.22: content, ] M ; , CU, RB1

7.23: should, ] M ; ; CU, RB1

7.24: sheep shearing ] M ; sheep-shearing CU, RB1 
7.24: course ] M, CU ; , RB1

7.25: days' ] CU, RB1 ; days $\mathbf{M}$

7.26: tenth ] $\mathbf{M} ; 10^{\text {th }} \mathbf{C U}, \mathbf{R B 1}$

7.27: first ] $\mathbf{M} ; 1^{\text {st }} \mathbf{C U}, \mathbf{R B 1}$

7.27: first; ] M ; , CU, RB1

7.27: way,-— ] RB1 ; , M ; - CU

7.28: at Ventura ] M, RB1 ; in Ventura CU

7.29: Lopez's;- - ] M ; - CU ; , -

7.29: Yes ] M ; , CU, RB1

7.29: tenth ] $\mathbf{M} ; \sim 10^{\text {th }} \mathbf{C U}, \mathbf{R B 1}$

7.30: here,-—] RB1 ; ; M ; - CU

7.32: Yes ] M, RB1; , CU

7.32: bed, ] CU, RB1 ; bed, like a giant, $\mathbf{M}$

7.34: creak, ] M ; ; CU, RB1

7.36: truth ] M ; , CU, RB1

7.36: sheep-shearing, ] M ; . CU, RB1

7.36: brisk ] M ; , CU, RB1

7.37: worked, ] M ; , CU, RB1

7.39: mother, ] M ; . CU, RB1

8.1: Can, ] M ; C CU, RB1

8.2: you, ] M ; . CU, RB1

8.3: he, ] M ; ! CU, RB1

8.4: him, ] M ; , CU, RB1

8.5: here;-—] M ; ; CU, RB1

8.5: sheep shearing ] $\mathbf{M}$; sheep-shearing $\mathbf{C U}, \mathbf{R B 1}$

8.5: please ] $\mathbf{M}$; , CU, RB1

8.6: say, ] M ; CU, RB1

8.6: place, ] M ; CU, RB1

8.7: Señora ] CU, RB1 ; Senora $\mathbf{M}$

8.8: men, ] M ; , CU, RB1

8.8: have; ] M ; , CU, RB1

8.10: everywhere, ] $\mathbf{M}$; CU, RB1

8.11: money ] $\mathbf{M}$; , CU, RB1

8.13: sheep shearing ] $\mathbf{M}$; sheep-shearing $\mathbf{C U}, \mathbf{R B 1}$

8.15-16: and moreover, ] $\mathbf{M}$; and, moreover, CU, RB1

8.15: Señora ] CU, RB1 ; Senora M

8.15: had had in ] CU, RB1; had in $\mathbf{M}$

8.16: himself, ] M; , CU, RB1

8.16: suspected, ] M ; . CU, RB1

8.17: son's ] CU, RB1 ; sons $\mathbf{M}$

8.17: him, ] M ; CU, RB1

8.18: sheep shearing ] $\mathbf{M}$; sheep-shearing $\mathbf{C U}, \mathbf{R B 1}$

8.19: Salvierderra, ] M ; . CU, RB1

8.22: way, ] M ; CU, RB1

8.23: appear ] CU, RB1 ; , M 
8.24: foot,-] RB1; ; $\mathbf{M} ; \sim-\mathbf{C U}$

8.24: this is ] CU, RB1; , M

*8.25: triumph, ] CU, RB1; . $\mathbf{M}$

8.25: Fates, ] M ; , CU, RB1

8.25: Fate ] M ; fate CU, RB1

8.26: world's ] CU, RB1 ; worlds M

8.27: power, ] M ; . CU, RB1

*8.27: degree. ] CU, RB1 ; : M

8.27: By it, ] M ; CU, RB1

*8.28: sovereigns; ] CU, RB1 ; , M

8.28: grasped ] M ; , CU, RB1

8.28: held ] M ; , CU, RB1

8.29: with, ] M ; CU, RB1

8.30: instances, ] M ; , CU, RB1

8.30: success, ] M ; C CU, RB1

8.31: instinct, ] $\mathbf{M} \sim \mathbf{C} \mathbf{C U}, \mathbf{R B 1}$

8.33: talent, ] M ; . CU, RB1

8.35: Señora ] CU, RB1 ; Senora $M$

8.35: Señora ] M, RB1, ; The Señora CU

6.26: re-buckled

Line End Hyphenations:

6.27: un-kissed

6.28: un-certain

7.4: over-heard

7.33: bed-posts

8.11: un-belief

\section{Chapter 26}

9.1: the East ] CU, RB1 ; to the East $\mathbf{M}$

9.2: both were ] CU, RB1 ; were both $\mathbf{M}$

*9.4: Thar! ] M ; , CU, RB1

*9.4: Thar, ] M ; thar, CU, RB1

*9.4: naow, ] M ; naow! CU, RB1

9.4: yer ] $\mathbf{M}$; Yer CU, RB1

9.4: agin ] M, RB1; ag'in $\mathbf{C U}$

9.5: eyelids ] M ; , CU, RB1

9.7: nothin'; ] M ; . CU, RB1

9.7: sleep ] M ; , CU, RB1

9.10: came, ] M ; - CU ; , - RB1

9.12: Yes ] M ; , CU, RB1

9.12: here ] M ; , CU, RB1 
*9.12: Felipe. ] M, CU ; ; RB1

9.14: sleep, ] M, RB1 ; $\mathbf{C U}$

9.14: Ri ] M ; , CU, RB1

9.14: sigh ] M ; , CU, RB1

9.14: deep drawn ] M ; deep-drawn CU, RB1

9.15: groan, ] M ; . CU, RB1

9.16: agin ] M, RB1 ; ag'in $\mathbf{C U}$

9.18: soul, ] M ; . CU, RB1

9.18: constancy, ] $\mathbf{M}$; . CU, RB1

9.19: this ] $\mathbf{M} ; \sim, \mathbf{C U}, \mathbf{R B 1}$

9.19: faith ] M ; , CU, RB1

9.20: who- ] M ; CU, RB1

9.21: about ] M ; , CU, RB1

9.21: destitute ] $\mathbf{M} ; \sim, \mathbf{C U}, \mathbf{R B 1}$

*9.21: afflicted ] M ; , CU, RB1

9.23: calm ] M ; , CU, RB1

*9.24: whispered, ] CU, RB1 ; - M

9.24: me ] M ; , CU, RB1

9.27: again; ] M ; , CU, RB1

9.31: responded, ] M ; : CU, RB1

9.35: week ] M ; , CU, RB1

9.35: agin ] M, RB1 ; ag'in $\mathbf{C U}$

9.35: ye, ] M ; . CU, RB1

9.36: thar's ] CU, RB1 ; thars $M$

9.36: up ] M ; , CU, RB1

9.39: Yes ] M ; , CU, RB1

9.39: dear. ] M ; , CU, RB1

9.39: Home ] M ; home CU, RB1

*10.2: time. ] M, RB1 ; ! CU

10.3: Señora's ] CU, RB1 ; Senora's M

*10.6: then, ] M ; . CU, RB1

10.6: tears; ] $\mathbf{M}$; . CU, RB1

*10.7: Felipe, ] M ; , CU, RB1

10.8: loyalty ] M ; , CU, RB1

10.9: Felipe!"] M ; Felipe"! CU, RB1

*10.10: life;- ] M ; - CU ; ,- RB1

10.10: won; ] M ; , CU, RB1

10.13: weather beaten ] $\mathbf{M}$; weather-beaten CU, RB1

10.17: when ] $\mathbf{M}$; , CU, RB1

10.18: water, ] $\mathbf{M} ; \sim$, CU, RB1

10.19: which ] M ; , CU, RB1

10.23: village, ] M ; CU, RB1

10.24: night, ] CU, RB1 ; night, ten, fifteen, twenty miles, $\mathbf{M}$

10.24: anything ] $\mathbf{M}$; , CU, RB1

10.25: country, ] $\mathbf{M} ; \sim$, CU, RB1 
10.26: travelled ] M, RB1 ; traveled CU

10.27: home, ] M ; , CU, RB1

10.27: South ] M ; south CU, RB1

*10.27: South, ] M ; ; CU, RB1

*10.28: hanged, ] M ; ; CU ; ,- RB1

10.28: yes ] M ; , CU, RB1

*10.30: Señor ] CU, RB1 ; Senor M

*10.30: Senor, ] M ; Señor CU, RB1

*10.30: Farrar ] CU, RB1 ; Farrell M

*10.31: of, ] CU, RB1 ; ; M

*10.32: judges; ] CU, RB1 ; - M

*10.32: bullet, ] CU, RB1 ; ! M

*10.32: that ] CU, RB1 ; That $\mathbf{M}$

10.35: he himself ] M, RB1 ; omit himself $\mathbf{C U}$

10.35: knew; ] $\mathbf{M}$; - CU ; ,— RB1

10.36: he, ] M ; CU, RB1

10.36: Ramona; ] M, CU ; : RB1

10.37: intent; ] M, RB1 ; : CU

10.38: knew, ] M ; CU, RB1

10.40: that ] M ; , CU, RB1

11.1: Señor ] CU, RB1 ; Senor M

11.1: explain, ] M ; ; CU, RB1

11.2: farther ] M, RB1 ; further $\mathbf{C U}$

11.3: speak, ] M ; . CU, RB1

11.5: recal ] $\mathbf{M}$; recall $\mathbf{C U}, \mathbf{R B 1}$

11.5: face, ] M ; CU, RB1

11.6: recal ] M ; , CU, RB1

11.6: this, ] M, RB1 ; $\mathbf{C U}$

11.7: scene, ] M ; ; CU, RB1

11.7: and, ] M ; CU, RB1

11.7: now, ] M, RB1 ; CU

11.8: thing ] $\mathbf{M} ; \sim, \mathbf{C U}, \mathbf{R B 1}$

11.8: too ] M ; , CU, RB1

11.9: wonder, ] M ; CU, RB1

11.9: least ] M ; , CU, RB1

11.11: time ] CU, RB1 ; , M

*11.11: investigated, ] CU, RB1 ; . $\mathbf{M}$

11.11: unfortunate; ] M, CU ; . RB1

11.11: and ] M, CU ; And RB1

11.12: clue ] M ; clew CU, RB1

11.12: horse, ] M, RB1 ; $\mathbf{C U}$

11.12: poor ] $\mathbf{M}$; , CU, RB1

11.12-13: half | crazed ] M ; half-crazed CU, RB1

11.13: well-known ] M ; well known CU, RB1

11.14: thing ] M ; , CU, RB1 
11.14: surely ] M ; , CU, RB1

11.14: horse thief ] M ; horse-thief CU, RB1

11.15: with, ] M ; CU, RB1

11.15: well known ] M ; well-known CU, RB1

11.16: him, ] M, RB1 ; $\mathbf{C U}$

11.18: separate, ] $\mathbf{M}$; CU, RB1

11.18: nature;-—] M ; CU, RB1

11.19: country; ] M ; , CU, RB1

11.20: time, ] M ; , CU, RB1

*11.21: not; ] M ; , CU, RB1

11.22: disappeared, ] M, RB1 ; . CU

11.22: office ] M ; , CU, RB1

*11.22: morning ] M ; , CU, RB1

11.24: Indian ] M ; , CU, RB1

11.24: Assis ] $\mathbf{M}$; , CU, RB1

*11.24: Judge ] M, CU ; judge RB1

*11.24: Judge, ] CU ; . M ; judge, RB1

*11.25: say, ] CU, RB1 ; . M

11.26: Ramona's ] M ; , CU, RB1

11.26: wife's ] M ; , CU, RB1

*11.26: at any rate, "her ] $\mathbf{M}$; at "any rate, her CU, RB1

11.28: foster sister ] M ; foster-sister CU, RB1

11.28: foster sister, ] $\mathbf{M}$; foster-sister; CU, RB1

11.28: Señor ] CU, RB1 ; Senor M

11.29: him, ] M ; . CU, RB1

11.30: brute, ] M ; ! CU, RB1

11.30: and Felipe ] M, RB1 ; And Felipe CU

*11.32: fled ] CU, RB1 ; , M

11.34: Wall ] $\mathbf{M}$; , CU, RB1

11.35: likes ] M ; , CU, RB1

11.36: Indian's ] M ; Injun's CU, RB1

11.36: ter yer, ] $\mathbf{M} ; \sim$. CU, RB1

11.37: die; ] M, CU ; : RB1

11.38: Farrar ] M ; , CU, RB1

11.38: he's nothin'] CU, RB1 ; hes nothin $\mathbf{M}$

11.39: he's got ] CU, RB1; hes got $\mathbf{M}$

11.39: arter him ] M, CU ; , RB1

11.39: It's jest ] M ; Its jest CU, RB1

11.39: gawn: ] M ; ; CU, RB1

11.40: one; ] M ; . CU, RB1

12.1: hung; ] M ; , CU, RB1

12.1: done. ] M ; , CU, RB1

12.1: 'N' I don't ] M ; 'n' I don't CU, RB1

12.2: nuther; ] M ; , CU, RB1

12.2: high strung ] M ; high-strung CU, RB1 
12.3: Farrar ] M ; , CU, RB1

12.3: it's ] CU, RB1 ; its $M$

12.4: raound, ] $\mathrm{M} ; \sim$, CU, RB1

12.4: yeow ] M ; , CU, RB1

12.5: foller him ] M ; , CU, RB1

12.5: day, ] M, RB1 ; $\mathbf{C U}$

12.5: dies, ] CU, RB1 ; ; M

*12.5: arter; ] CU, RB1 ; . M

12.6: dead, ] M ; , CU, RB1

12.6: man, ] M ; CU, RB1

12.7: Tenessee; ] M ; . CU, RB1

12.7: wan't ] M ; wa'n't CU, RB1

12.7: then; ] M , CU, RB1

12.8: gourds ] M ; , CU, RB1

*12.8: there ] M ; thar CU, RB1

12.9: a runnin' ] M, RB1 ; a-runnin' CU

12.10: up,- ] RB ; , $\mathbf{M} ; \sim-\mathbf{C U}$

12.10: children's ] CU, RB1 ; childrens $\mathbf{M}$

12.11: mothers ] $\mathbf{M} ; \sim, \mathbf{C U}, \mathbf{R B 1}$

12.11: know,-— ] RB1; , M ; - CU

12.11: abaout it, ] M ; ; CU, RB1

12.11: last, ] M ; CU, RB1

12.12: butcher knife ] $\mathbf{M}$; butcher-knife CU, RB1

12.13: somehow, ] M ; CU, RB1

12.14: they put't off ] $\mathbf{M} ; \sim, \mathbf{C U}, \mathbf{R B 1}$

12.15: free; ] M, RB1 ; : CU

*12.16: sed he, ] CU, RB1 ; , M

12.17: 'Jake',—] M, RB1 ; - CU

12.17: 'Jake,'] RB, CU ; - M

12.17: 'Uncle Jake',- ] RB ; , M ; - CU

12.19: "Why ] CU, RB1 ; “ M

12.19: ye.'] CU, RB1; ” M

12.20: 'Yes ] CU, RB1 ; “ M

*12.20: hain't; ] RB1 ; ! M ; , CU

12.21: narrer ] M ; , CU, RB1

12.21: day, ] M ; ; CU, RB1

12.22: t'other, ] $\mathbf{M} ; \sim$; CU, RB1

*12.22: it!" ] M ; it!' CU, RB1

12.23: anythin'] M, CU ; ennythin' RB1

12.25: Wall ] $\mathbf{M} ; \sim, \mathbf{C U}, \mathbf{R B 1}$

12.26: agin ] M, RB1; ag'in CU

12.26: agin, ] M ; ; CU, RB1

12.27: him, — ] RB1 ; , M ; - CU

*12.27: him, ] M ; - CU ; ,- RB1

12.28: Wal! ] M ; , CU, RB1 
12.29: me; ] M ; , CU, RB1

12.29: him, ] M ; CU, RB1

12.30: everywhar.' ] CU, RB1 ; everywhar. M

12.32: think't was ] M ; think't wuz CU, RB1

12.32: said't was ] M ; said't wuz CU, RB1

12.33: Farrar; ] M ; . CU, RB1

12.33: he'll ] M ; He'll CU, RB1

12.34: hanged, ] M, CU ; RB1

12.34: misery! ] M ; . CU, RB1

12.34: way ] M ; , CU, RB1

*12.35: listened ] CU, RB1 ; , M

12.36: untouched, ] M ; ; CU, RB1

12.37: western ] M ; Western CU, RB1

12.37: frontiers man] $\mathbf{M}$; frontiersman $\mathbf{C U}, \mathbf{R B 1}$

12.37: frontiers man, ] M ; CU, RB1

12.38: strata,-— ] RB1 ; , M ; - CU

12.38: days, ] M ; CU, RB1

*12.40: nature ] CU, RB1 ; , M

*12.40: remains- ] CU, RB1 ; , M

*13.1: fossilized-] CU, RB1 ; , M

13.1: a realm ] $\mathbf{C U}, \mathbf{R B 1}$; an age $\mathbf{M}$

*13.1: customs, ] CU, RB1 ; . M

13.4: definitions ] $\mathbf{M}$; , CU, RB1

13.5: ears; ] M ; , CU, RB1

*13.6: speech, ] M ; . CU, RB1

13.9: him in, ] $\mathbf{M} ; \sim$, CU, RB1

13.10: yet, ] M ; CU, RB1

13.11: so Aunt ] M ; so, Aunt CU, RB1

*13.11: so. I ] M ; so! I CU, RB1

13.11: spose ] M ; s'pose CU, RB1

13.12: peace, ] M ; , CU, RB1

13.12: world ] M ; , CU, RB1

13.13: see, ] M ; $\wedge \mathbf{C U}, \mathbf{R B 1}$

13.13: horse stealin' ] M ; horse-stealin' CU, RB1

*13.13: different. ] CU, RB1 ; ; $\mathbf{M}$

13.13-14: hoss | thief ] CU, RB1 ; hoss-thief CU, RB1

13.14: that; a ] $\mathbf{M}$; that. A CU, RB1

13.14: horse stealin' ] M ; horse-stealin' CU, RB1

13.15: shot; ] M, RB1 ; : CU

13.15: be ] M ; , CU, RB1

13.16: Ri's ] CU, RB1 ; Ris $\mathbf{M}$

13.17: hosses, ] M ; $\wedge \mathbf{C U}, \mathbf{R B 1}$

*13.18: crazy. ] CU, RB1 ; $\wedge \mathbf{M}$

13.19: Farrar ] CU, RB1 ; Farrell M

13.20: ez ] M ; , CU, RB1 
13.20: say ] M ; , CU, RB1

13.21: it? 'N' ] M ; it; 'n' CU, RB1

13.21: house, ] M ; $\wedge \mathbf{C U}, \mathbf{R B 1}$

13.21: anybody ] M, CU ; ennybody RB1

13.22: poor ] $\mathbf{M}$; , CU, RB1

13.22: miserable ] $\mathbf{M}$; , CU, RB1

13.22: knock kneed ] M ; knock-kneed CU, RB1

13.23: wan't ] M ; wa'n't CU, RB1

13.23: Jim's ] CU, RB1 ; Jims M

13.23: wuz ] M, CU ; was RB1

13.25: thar, ] M ; , CU, RB1

13.26: hosses; what ] $\mathbf{M}$; hosses. What CU, RB1

13.26: wan't ] M ; wa'n't CU, RB1

13.27: hoss thieves ] $\mathbf{M}, \mathbf{C U}$; hoss thieves RB1

13.27: yit, ] M ; . CU, RB1

13.28: refference ] M, RB1 ; reference $\mathbf{C U}$

13.31: Ri, ] M ; CU, RB1

*13.32: tireless, ] CU, RB1 ; . $\mathbf{M}$

13.34: gone, ] M, RB1 ; CU

13.35: simple hearted ] $\mathbf{M}$; simple-hearted CU, RB1

*13.35: hearted ] CU, RB1 ; , M

13.38: see, ] M ; CU, RB1

13.38: most; 'n' ] M, CU ; most. 'N' RB1

13.38: wan't ] M ; wa'n't CU, RB1

13.39: know ] M ; , CU, RB1

13.40: anywhar ] M, CU ; RB1

*14.1: took care on, ] M ; , CU, RB1

14.3: Injuns ] CU, RB1 ; Indians $\mathbf{M}$

14.3: naow ] M ; , CU, RB1

14.4: know ] M ; , CU, RB1

14.5: their selves ] $\mathbf{M}$; theirselves CU, RB1

14.5: selves. ] CU, RB1; ; M

*14.5: tew; ] CU, RB1 ; . M

14.10: good will ] M ; good-will CU, RB1

14.10: toward ] M, CU ; towards RB1

14.11: loss,-- ] RB1 ; , M ; -- CU

14.11: them, ] M ; , CU, RB1

14.12: world, ] M ; CU, RB1

14.12: anew; ] M ; , CU, RB1

14.12: deepened; ] M ; , CU, RB1

*14.13: Ramona, ] CU, RB1 ; . M

14.13: sister,-- ] RB1 ; , M ; -- CU

14.14: offer; but ] M, CU ; offer. But RB1

14.14: nothing ] M ; , CU, RB1

14.16: from death ] M ; , CU, RB1 
14.18: again, ] $\mathbf{M}$; , CU, RB1

14.19: babe, ] M ; CU, RB1

14.20: "Sister! You ] M ; Sister, you CU, RB1

14.20: cried. ] M ; ; CU, RB1

14.20: thank you! ] M ; : CU ; ; RB1

14.21: you, ] M ; . CU, RB1

*14.25: girlhood, ] CU, RB1 ;

14.26: then,-- ] RB1 ; , M ; -- CU

14.26: duties,-- ] RB1 ; , M ; -- CU

14.27: calm ] M ; , RB1, CU

14.27: burdens, ] M, CU ; . RB1

14.28: life, ] M ; ; CU, RB1

14.29: dry ] M ; , CU, RB1

14.30: practical ] M ; , CU, RB1

14.31: Saints ] M ; saints CU, RB1

*14.31: said, ] CU, RB1 ; . M

14.32: Pears ] M ; 'Pears CU, RB1

14.32: more 'n' ] M ; more'n CU, RB1

14.33: Thar's ] CU, RB1 ; Thars $\mathbf{M}$

14.35: picters ] M ; , CU, RB1

14.35: beads ] M ; , CU, RB1

14.35: it's ] M ; t's RB1, CU

14.37: agin it] M, RB1 ; ag'in it $\mathbf{C U}$

14.37: agin Injuns ] $\mathbf{M}$; ag'in Injuns CU, RB1

14.37: Pears ] M ; 'Pears CU, RB1

14.37: getting' ] M ; gittin' CU, RB1

14.38: Injun ] M ; , CU, RB1

14.38: mebbe ] M ; , CU, RB1

14.40: times, ] M ; CU, RB1

14.40: side, ] M ; CU, RB1

15.1: thought ] $\mathbf{M} ; \sim, \mathbf{C U}, \mathbf{R B 1}$

15.1: treason ] M, RB1 ; , CU

15.2: thought, ] M ; ; CU, RB1

15.3: Bernardino, ] M ; , CU, RB1

15.4: pretense ] M, RB1 ; pretence $\mathbf{C U}$

15.9: pattern as ] $\mathbf{M}$; pattern, as CU, RB1

15.10: stripes ] M, RB1 ; stripe CU

15.10: stripes, ] M ; stripe $\mathbf{C U}$; stripes, $\mathbf{R B 1}$

15.10: colors; ] $\mathbf{M}$; $\mathbf{C U}$; , RB1

15.13: subject ] M ; , CU, RB1

15.13: too ] M ; , CU, RB1

15.14: it's called] CU, RB1 ; its called $\mathbf{M}$

15.14: 'hit-er-miss' ] CU, R.B1 ; hit-er-miss $\mathbf{M}$

15.14: it's 'hit ] CU, RB1 ; its 'hit $\mathbf{M}$

15.15: pears ] M ; 'pears CU, RB1 


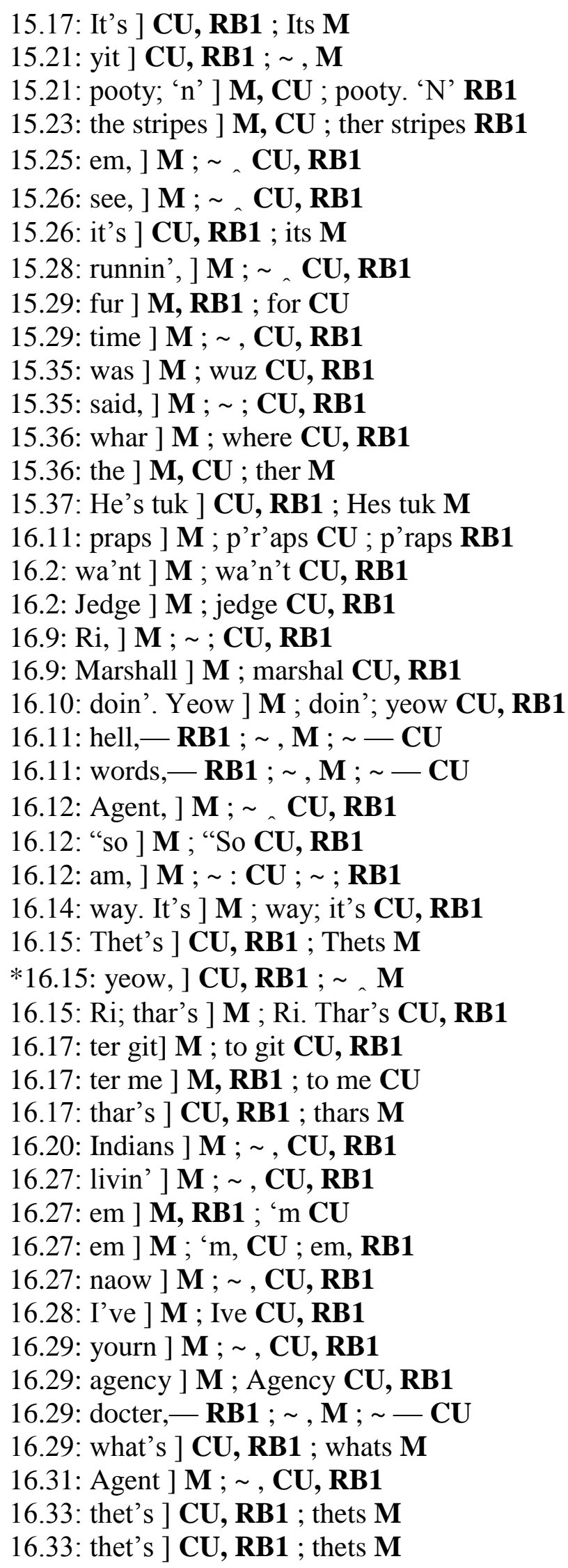


16.33: sed ] M, RB1 ; said CU

16.33: thet's ] CU, RB1 ; thets $\mathbf{M}$

16.34: murdered,- ; M, RB1 ; - CU

16.34: thet's ] RB1, CU ; thets $\mathbf{M}$

16.34: books ] M, RB1; book CU

16.35: it; he ] M, CU ; it. He RB1

16.35: high spereted ] $\mathbf{M}$; high-spereted CU, RB1

16.36: he'd ] CU, RB1; hed M

16.38: him, ] M ; . CU, RB1

16.38: askin', 'n' ] M ; askin'; 'n' CU ; askin'. 'N' RB1

16.39: her, ] M ; ; CU, RB1

16.39: thet ] M ; , CU, RB1

17.1: Naow ] M ; , CU, RB1

17.1: wan't ] M ; wa'n't CU, RB1

17.1: docter's ] CU, RB1 ; docters $\mathbf{M}$

17.2: Praps ] M ; Pr'aps CU, RB1

*17.2: thet. ] CU, RB1 ; ? M

17.2: Ramony, ] M ; , CU, RB1

17.4: No! ] M ; , CU, RB1

17.4: Agent. ] M ; ; CU, RB1

17.4: that. He ] M ; that; he CU, RB1

17.6: allow ] $\mathbf{M} ; \sim, \mathbf{C U}, \mathbf{R B 1}$

17.6: Ri, ] M ; ; CU, RB1

17.6: pears ] M ; 'pears CU, RB1

17.9-10: hap | hazard ] M ; hap-hazard CU, RB1

17.11: resumed, ] M ; : CU, RB1

17.12: tew ] M ; ter CU, RB1

*17.13: Injuns. ] CU, RB1 ; ? M

17.14: one, ] M, RB1 ; CU

17.14: thet's ] CU, RB1 ; thets $\mathbf{M}$

17.15: ennything, - ] RB1 ; ; M ; - CU

17.15: food ] M ; , CU, RB1

17.16: them, ] M ; CU, RB1

17.17: suffering; ] M, RB1 ; , CU

*17.17: Agent ] CU, RB1 ; agent M

*17.17: Agent, ] RB1 ; agent, $\mathbf{M}$; Agent; CU

17.17: department ] M ; Department CU, RB1

17.18: enough ] M ; , CU, RB1

17.18: however ] M ; , CU, RB1

17.18: village; ] M, RB1 ; : CU

17.18: see ] M, RB1 ; , CU

17.19: self supporting ] M ; self-supporting CU, RB1

17.20: Thet's jest ] CU, RB1 ; Thets jest $\mathbf{M}$

17.20: it; ] M ; , CU, RB1

17.20: Thet's what ] CU, RB1 ; Thets what $\mathbf{M}$

17.20: thet's why ] CU, RB1 ; thets why $\mathbf{M}$ 
17.21: tis ] $\mathbf{M}$; ' $t$ is $\mathbf{C U}, \mathbf{R B 1 1}$

17.21: em; ] M, CU ; . RB1

17.22: folks ] CU, RB1 ; anybody $\mathbf{M}$

17.23: ‘em, 一] RB1 ; , M ; - CU

*17.24: say—] CU, RB1 ; , M

17.26: so, ] M ; . CU, RB1

17.26: impulse,-—] RB1 ; ; M ; - CU

17.26: say, ] M ; . CU, RB1

17.27: shoes! ] M ; . CU, RB1

17.28: that ] M ; , CU, RB1

17.28: Agent ] $\mathbf{M} ; \sim, \mathbf{C U}, \mathbf{R B 1}$

17.30: Wall ] M ; , CU, RB1

17.30: satisfyin' ] CU, RB1 ; satisfyin $\mathbf{M}$

17.31: Ri, ] M ; ; CU, RB1

17.33: there ] $\mathbf{M} ;$ , CU, RB1

17.33: he ] M ; , CU, RB1

17.35: lead pencil ] $\mathbf{M}$; lead-pencil CU, RB1

17.35: buy; ] $\mathbf{M}$; . CU, RB1

*17.37: good naturedly ] M ; good-naturedly CU, RB1

17.37-38: good naturedly | satirical $\mathbf{M}$; omit $\mathbf{C U}$; good-naturedly satirical RB1

18.1: home ] M, RB1 ; omit CU

18.1: home, ] M ; omit $\mathbf{C U}$; $\mathbf{R B 1}$

18.2: creatures ] $\mathbf{M} ; \sim, \mathbf{C U}, \mathbf{R B 1}$

18.2: Benito ] M ; , CU, RB1

18.2: gaily ] M ; gayly $\mathbf{C U}, \mathbf{R B 1}$

18.2: along; ] M ; , CU, RB1

18.3: side, - ] RB1; , M ; - CU

18.3: Felipe, - ] RB1; , M ; - CU

18.4: old, - ] RB1 ; ; $\mathbf{M} ; \sim-\mathbf{C U}$

18.4: it, ] M ; CU, RB1

18.5: her, ] M ; . CU, RB1

*18.5: unreal? ] CU, RB1; ! M

18.5: arms, - ] RB1 ; . M ; - CU

18.6: she ] RB1, CU ; She M

18.6: she ] $\mathbf{M}$; , RB1, CU

18.6: too ] M ; , RB1, CU

18.7: paralyzed; nature ] $\mathbf{M}$; paralyzed. Nature CU, RB1

18.8: blow, ] M ; , CU, RB1

18.12: his, ] M ; CU, RB1

18.14: it, ] M ; CU, RB1

18.14: towards ] M, RB1 ; toward CU

18.14: thought, ] M ; . CU, RB1

18.14: "to ] M ; "To CU, RB1

18.15: woe, ] M ; . CU, RB1

*18.16: himself, ] M, CU ; ,- $\mathbf{R B 1}$ 
18.17: child, ] M ; ; CU, RB1

18.19: her, ] M ; : CU, RB1

18.23: selfish, ] M ; CU, RB1

18.24: back, ] M ; ; CU, RB1

18.25: wept ; ] M ; , CU, RB1

18.25: sinned; ] M ; , CU, RB1

18.28: do! ] CU, RB1 ; , M

*18.29: not, ] CU, RB1 ; ! M

18.30: recollect ] M ; , CU, RB1

18.30: Felipe ] M ; , CU, RB1

18.31: many many ] $\mathbf{M}$; many, many CU, RB1

18.31: night ] M ; , CU, RB1

18.32: weep ] $\mathbf{M}$; , CU, RB1

18.32: me, ] M ; ; CU, RB1

18.34: thinks, ] M ; , CU, RB1

18.35: learning ] M ; , CU, RB1

18.35: years, ] M ; , CU, RB1

18.36: side, ] M ; CU, RB1

18.38: child, ] M ; , CU, RB1

18.39: soul. You ] M ; soul, you CU ; soul; you RB1

18.39: that, ] M ; CU, RB1

18.39: eyes; and ] M, CU ; eyes. And RB1

19.1: speak, ] M ; , CU, RB1

19.1: heart, ] M ; . CU, RB1

19.2: air, ] M ; CU, RB1

19.2: sky, ] M ; CU, RB1

19.4: it, ] M ; CU, RB1

19.5: yet, ] M ; , CU, RB1

19.6: lovely ] M ; , CU, RB1

19.6: sorrowing ] $\mathbf{M} ; \sim, \mathbf{C U}, \mathbf{R B 1}$

19.7: servants ] M ; , CU, RB1

19.8: court yard ] M ; court-yard CU, RB1

19.8: Marda, ] M ; CU, RB1

19.8: Can, ] M ; CU, RB1

19.9: absent,—] RB1; , M ; - CU

19.9: married, ] M ; CU, RB1

19.13: home coming ] M ; home-coming CU, RB1

19.13: one, ] M ; CU, RB1

19.14: Señorita ] CU, RB1 ; Senorita M

19.15: sorrow; ] M ; , CU, RB1

19.16: associations; "and ] M ; associations. "And CU, RB1

19.17: Señora ] CU, RB1 ; Senora M

19.17: gone ] $\mathbf{M} ; \sim, \mathbf{C U}, \mathbf{R B 1}$

19.17: too! ] M ; , CU, RB1 
19.18: all, ] M ; CU, RB1

19.18: Señora ] CU, RB1 ; Senora M

19.18: here! ] M ; . CU, RB1

*19.19: "Humph!" ] CU, RB1 ; . M

19.20: estate, ] M ; . CU, RB1

19.20: That's ] M ; that's CU, RB1

19.21: Señora ] CU, RB1 ; Senora M

19.21: died, ] M ; CU, RB1

19.21: Señorita ] CU, RB1; Senorita M

19.22: else; ] CU, RB1 ; ! M

*19.22: man! And ] CU, RB1 ; man; and M

19.22: Señor ] CU, RB1 ; Senor M

*19.23: Señorita ] CU, RB1 ; Senorita M

*19.23: Senorita, ] M ; Señorita CU, RB1

19.23: Señora ] CU, RB1 ; Senora M

*19.23: ashes! ] CU, RB1 ; . M

19.25: saw, ] M ; CU, RB1

19.25: Ramona, ] M, CU ; - RB1

19.26: face, ] M, CU ; - RB1

19.27: cheering; ] M ; , CU, RB1

19.28: Marda, ] M ; CU, RB1

19.28: baby, ] M ; CU, RB1

19.28: towards ] M, RB1 ; toward CU

19.29: said, ] M, CU ; . RB1

19.29: her old ] CU, RB1; her own old M

19.30: Señorita ] CU, RB1 ; Senorita M

19.30: Señorita ] CU, RB1; Senorita M

19.30: you ] M ; , CU, RB1

19.30: Señorita ] CU, RB1 ; Senorita M

19.30: cried, ] M ; ; CU, RB1

19.32: stood for a ] M, RB1 ; stood a CU

19.33: house, ] M ; ; CU, RB1

19.34: way, ] M ; ! CU, RB1

19.34: Dear! ] M ; dear, CU ; dear; RB1

19.34: Felipe; "it ] M ; Felipe. "It CU, RB1

19.36: Thanks ] M ; , CU, RB1

19.37: returning,_; RB1 ; ; M ; - CU

20.1: Yes! ] M ; ; CU, RB1

20.2: woman,- RB1 ; , M ; - CU

20.4: feature. ] M ; ? CU, RB1

20.5: change, ] $\mathbf{M}$; . CU, RB1

20.6: lover's ] CU, RB1 ; lovers $M$

20.7: face ] M ; , CU, RB1

20.8: Ri, ] M ; , CU, RB1

20.9: fashion: but ] $\mathbf{M}$; fashion. But CU, RB1 
20.9: Marda, ] M ; CU, RB1

20.9: when ] M ; , CU, RB1

20.10: half terrified ] M ; half-terrified CU, RB1

20.10: terrified ] $\mathbf{M} ; \sim, \mathbf{C U}, \mathbf{R B 1}$

20.10: low whispered ] $\mathbf{M}$; low-whispered CU, RB1

*20.10: Can's ] CU ; Cans M ; Can RB1

20.11: Señor ] CU, RB1 ; Senor M

*20.11: Señorita ] CU, RB1 ; Senorita M

*20.11: Senorita, ] M ; Señorita CU, RB1

20.11: ago,-—] RB1 ; . M ; - CU

20.11: what ] CU, RB1 ; What $\mathbf{M}$

20.12: yet! ] M ; ? CU, RB1

20.12: she ] CU, RB1 ; Marda M

20.12: breath, "its ] M, CU ; breath. "Its RB1

20.14: Señora ] CU, RB1 ; Senora M

20.14: often, ] M ; CU, RB1

20.14: about,—RB1; ; M ; - CU

20.15: child, ] M ; , CU, RB1

20.15: verandah ] $\mathbf{M}$; veranda $\mathbf{C U}, \mathbf{R B 1}$

20.15: everywhere; ] M, RB1 ; , CU

20.16: sunny ] M ; , CU, RB1

20.16: joyous ] M ; , CU, RB1

*20.16: child, ] CU, RB1 ; ; M

20.17: pictured; ] M ; , CU, RB1

20.17: friendless ] $\mathbf{M}$; , CU, RB1

20.18: now, ] M ; , CU, RB1

20.18: peace, ] M ; , CU, RB1

20.18: house,- RB1; , M ; - CU

20.20: him, ] M ; , CU, RB1

20.24: month, ] M ; C CU, RB1

20.25: life, ] M ; CU, RB1

20.28: mind,- - ] RB1 ; , M ; - CU

20.29: after day ] M ; , CU, RB1

20.31: words, ] M, RB1 ; . CU

20.32: him, ] M ; . CU, RB1

20.33: Oh ] M ; , CU, RB1

20.33: said, ] M ; . CU, RB1

*20.33: things; ] CU, RB1 ; , M

20.34: trouble ] M ; , CU, RB1

20.35: Señora ] CU, RB1 ; Senora M

20.37: shame stricken ] M ; shame-stricken CU, RB1

20.37: replied, ] M ; . CU, RB1

20.37: Dear Ramona ] CU, RB1 ; Dear omit $\mathbf{M}$

20.38: suppose, ] M ; , CU, RB1

20.39: them, ] M ; , CU, RB1 
20.40: Church ] M ; , CU, RB1

21.1: Felipe, ] M ; . CU, RB1

21.2: had sure ] CU, RB1; had had sure $\mathbf{M}$

21.5: haven't ] M ; have not CU, RB1

21.5: Señora ] CU, RB1 ; Senora $\mathbf{M}$

21.5: letter, ] M ; ! CU ; ? RB1

21.6: Yes ] M ; , CU, RB1

21.6: have; ] M ; , CU, RB1

21.7: said, ] M ; CU, RB1

21.7: Señora ] CU, RB1 ; Senora M

21.9: No ] M ; , CU, RB1

21.10: was ] M ; , CU, RB1

21.13: sure ] M ; , CU, RB1

21.16: it ] M ; , CU, RB1

21.18: them, ] M, RB1 ; $\mathbf{C U}$

21.19: thing, $-\mathbf{R B 1} ; \sim ; \mathbf{M} ; \sim-\mathbf{C U}$

21.19: father's ] CU, RB1 ; fathers $\mathbf{M}$

21.20: it, ] M ; ; CU, RB1

21.20: lost, ] M ; . CU, RB1

21.21: half day's ] M ; half-day's CU, RB1

21.22: day, ] M ; CU, RB1

21.22: Felipe, ] M ; ; CU, RB1

21.24: paper, ] M ; . CU, RB1

21.25: dies, ] M ; . CU, RB1

21.25: Church,-to ] RB1 ; Church? To M ; Church-to CU

*21.26: Barbara? ] CU, RB1 ; . M

21.27: Yes ] M ; , CU, RB1

21.27: Felipe, ] M ; ; CU, RB1

21.27: place; ] M ; . CU, RB1

21.29: years. ] M, CU ; ! RB1

21.30: so, ] M ; CU, RB1

21.31: mysterious ] $\mathbf{M} ; \sim, \mathbf{C U}, \mathbf{R B} 1$

21.33: household,-—] RB1; ; M ; - CU

21.33: eye; nothing ] $\mathbf{M}$; eye. Nothing $\mathbf{C U}, \mathbf{R B 1}$

21.34: peaceful ] M ; , CU, RB1

*21.35: sunny- ] M ; , CU, RB1

21.35: had each ] M, RB1 ; each had CU

21.37: verandah, ] $\mathbf{M}$; veranda $\mathbf{C U}, \mathbf{R B 1}$

21.37: verandah ] $\mathbf{M}$; veranda $\mathbf{C U}, \mathbf{R B 1}$

21.37: home, ] $\mathbf{M} ; \sim$, CU, RB1

21.38: frisking ] M ; , CU, RB1

21.38: laughing ] $\mathbf{M} ; \sim$, CU, RB1

21.39: child, ] M ; CU, RB1

21.39: shelter,- RB1; , M ; - CU

21.40: destiny, ] M ; , CU, RB1 
22.5: period ] $\mathbf{M}$; , CU, RB1

22.6: sight ] M ; , CU, RB1

22.7: Alessandro; but ] M ; Alessandro. But CU, RB1

22.9: day's ] M ; days CU, RB1

22.9: all ] M ; , CU, RB1

22.10: heart; ] M, RB1 ; : CU

22.11: prayer ] $\mathbf{M} ; \sim, \mathbf{C U}, \mathbf{R B 1}$

22.13: knew ] M ; , CU, RB1

22.13: too ] M ; , CU, RB1

22.14: nor ] CU, RB1; or $\mathbf{M}$

22.15: clearer sighted ] M ; clearer-sighted CU, RB1

22.16: lived, ] M ; . CU, RB1

22.16: act ] $\mathbf{M} ; \sim, \mathbf{C U}, \mathbf{R B 1}$

22.16: word ] $\mathbf{M}$; , CU, RB1

22.17: look ] M ; , CU, RB1

22.21: standards ] M, RB1 ; , CU

22.22: were,] M ; , CU, RB1

22.22: him, ] M ; CU, RB1

22.23: settlement, ] M ; . CU, RB1

22.23: development,-—RB1; , M ; - CU

22.23: disagreeable, ] M ; C CU, RB1

22.24: money, ] M ; , CU, RB1

22.25: mind, ] $\mathbf{M}$; , CU, RB1

22.25: gambling, ] $\mathbf{M}$; CU, RB1

22.28: temperament ] $\mathbf{M} ; \sim \mathbf{C U}, \mathbf{R B 1}$

22.30: Mexico,-—] RB1 ; ; $\mathbf{M} \sim-\mathbf{C U}$

22.30: Mexico, ] M ; CU, RB1

22.31: for, ] M ; CU, RB1

22.33: memory ] M, RB1 ; thought $\mathbf{C U}$

22.34: land ] M ; , CU, RB1

22.35: suffering? ] M, RB1 ; . CU

22.36: cried, ] $\mathbf{M}$; : CU, RB1

22.37: Saints ] M ; saints CU, RB1

22.38: be ] M ; , CU, RB1

23.2: daughter, ] $\mathbf{M} ; \sim$, CU, RB1

23.3: borne, ] M ; CU, RB1

23.10: beckoned,-—] RB1 ; , M ; - CU, RB1

23.13: devotion; and ] M, RB1 ; devotion. And CU

23.14: Surely ] M ; , CU, RB1

23.15: patient ] M, CU ; , RB1

23.15: dawned. ] M, CU ; ! RB1

23.16: province, ] $\mathbf{M} ; \sim$ CU, RB1

23.18: harder ] M ; CU, RB1

23.19: sisterliness ] M ; , CU, RB1 
23.23: her, ] M ; . CU, RB1

23.30: at her, ] M ; . CU, RB1

23.30: when ] $\mathbf{M} ; \sim$, CU, RB1

23.31: said ] $\mathbf{M}$; CU, RB1

23.32: Felipe! ] M ; . CU, RB1

23.32: cried, ] CU, RB1 ; . M

23.33: Ramona! My ] M ; Ramona, my CU, RB1

23.33: love, oh, ] M ; love! Oh, CU, RB1

23.33: me! ] M ; ? CU, RB1

23.34: surprise; only ] $\mathbf{M}$; surprise. Only CU, RB1

23.37: brother, ] $\mathbf{M} ;$ ! CU, RB1

23.39: terror, ] M ; CU, RB1

24.1: one, ] M, CU ; ! RB1

24.2: long,-—] RB1 ; , M ; - CU

24.2: long. ] M ; ! CU, RB1

24.3: breast; ] M ; , CU, RB1

24.4: fell rose ] M ; fell, rose CU, RB1

24.9: not ] M ; , CU, RB1

24.9: Felipe-] M ; . CU, RB1

24.9: you! ] M ; ? CU, RB1

24.12: him- ] M ; , CU, RB1

24.13: man;- ] M ; ; CU, RB1

24.13: but ] M ; , CU, RB1

24.13: Felipe,- ] RB1 ; , M ; - CU

24.14: whisper,- ] RB1; , M ; - CU

24.14: know ] M ; , CU, RB1

24.14: Felipe ] M ; , CU, RB1

24.14: dead,—dead? ] RB1 ; dead? Dead? M ; dead—dead? CU

24.15: dead? ] RB1, CU ; Dead? $\mathbf{M}$; ]

24.16: wife ] M ; , CU, RB1

24.16: dead? ] M ; ! CU, RB1

24.20: Ah ] M ; , CU, RB1

24.21: know ] M ; , CU, RB1

24.21: gentle ] M ; , CU, RB1

24.21: faithful ] $\mathbf{M}$; , CU, RB1

24.23: her, ] M ; , CU, RB1

24.23: words ] $\mathbf{M} ; \sim, \mathbf{C U}, \mathbf{R B 1}$

24.24: calmest ] M ; , CU, RB1

24.24: Ah ] M ; ah, CU, RB1

24.25: Ramona, ] M ; CU, RB1

24.25: crying, ] CU, RB1 ; CU, RB1

24.26: die, ] M ; . CU, RB1

24.27: now ] M ; , CU, RB1

*24.28: her. Could ] CU, RB1 ; her; could

24.31: solemnly ] M ; , CU, RB1 
24.34: so ] M, CU ; , RB1

24.39: arrival, ] M ; , CU, RB1

24.40: Marda, ] M ; CU, RB1

25.3: Señora ] CU, RB1 ; Senora M

25.3: city, ] M ; , CU, RB1

25.4: demeanor, ] $\mathbf{M}$; CU, RB1

25.7: calling ] M ; , CU, RB1

25.7: other ] $\mathbf{M} ; \sim$, CU, RB1

25.8: saying ] M ; , CU, RB1

25.8: Majella. ] M ; ! CU, RB1

25.8: her loyal ] $\mathbf{M}$; $\mathbf{C U}, \mathbf{R B 1}$

25.9: A loyal ] $\mathbf{M}$; , CU, RB1

25.9: was; ] M, CU ; ,- RB1

25.9: serene; few ] M, CU ; serene. Few RB1

25.9: blest, ] M ; CU, RB1

25.10: Señor ] CU, RB1; Senor M

25.12: one; ] M ; : CU, RB1

25.12: name ] M ; , CU, RB1

25.13: step daughter ] M ; stepdaughter CU ; step-daughter RB1

*25.13: Señor ] CU, RB1 ; Senor M

*25.13: Senor;- - ] M ; Señor - CU ; Señor,- RB1

25.13: Ramona,-— ] CU, RB1 ; , M 


\section{Textual Notes}

1.2: fates] Although Jackson sometimes capitalizes "fate" or "fates" and sometimes not, there is no evidence to suggest that she intended these capitalizations to be standardized, or vice versa. Apparently, $\mathrm{CU}$ and RB1 standardize her capitalizations based on the frequency that she capitalizes the particular word. Because she capitalizes fate more often than not, they assume that it is meant to always be capitalized.

1.8: Señora; 1.8: Señora,] Even though Jackson can be inconsistent with certain grammar rules, she usually does follow the rule of putting a comma in front of "who" that is a nonrestrictive clause. I have therefore used the RB and CU comma here. I have also used the RB1 CU spelling of Senora, which includes the accent.

1.10: patch; ] The manuscript does not have a punctuation mark after patch, and since it is characteristic of Jackson's writing to have a semicolon before a coordinating conjunction, I have used the RB and CU punctuation here.

1.35: been, ] When she cancels a part of the sentence in the manuscript, Jackson has a tendency to not also revise the punctuation of the old sentence structure to reflect the construction of the new. In a proof phase, she likely would have gone to these places and added in the punctuation that she intended. The manuscript here reads: "been severat consultations". If she had kept "several consultations", a comma would not have been needed after "been", as indeed there is no comma there in the manuscript. I judge that the $\mathrm{CU}$ and RB1 insertion of a comma here reflects Jackson's revision in a proof phase. Therefore, I have kept the comma as being a product of authorial intention.

1.37: discussions ] There is no apparent reason for both $\mathrm{RB}$ and $\mathrm{CU}$ to both change this relatively trivial word. Probably Jackson herself changed it in a proof stage. The first word she used in the manuscript was "consultations". Then she crossed it out and wrote in "talks". It seems reasonable that she still might not have been happy with "talks" and wrote in "discussions" as her final choice.

2.1: coast ] Jackson writes in her manuscript: "...that had been driven up the coast, miles down the valley toward Ventura for pasture." Ascertaining the authorial punctuation mark here is tricky, since the comma after coast works for the both the old and new sentence structures. The possibility is strong that Jackson decided to leave in the comma while correcting her proofs. The deciding factor in determining the intended variant is Jackson's pattern of leaving in unwanted punctuation when she makes a cancel. With this factor in mind, I decided that RB1's reading reflects Jackson's intentions.

2.13: tones! ] Jackson does sometimes put exclamation marks in the middle of sentences. Especially since both CU and RB1 agree, the possibility is strong that the mark comes from a proof revision that Jackson made.

2.14-15: with a look to the fathoming of which he was as unequal as one of his own sheep would have been ] In her manuscript most of Jackson's cancels concern sentence 
structure and the order of words, versus word or punctuation changes. This reversal of clauses is in line with this tendency, so it seems likely that Jackson was the author of this change in sentence structure.

2.24: week or two, ] Jackson writes in the manuscript: "He will be well enough in a week, more ${ }^{\text {or two }}$ he thinks,". Likely this situation is another for which Jackson did not revise her punctuation when she revised her word choices. For this reason, I have indicated that the $\mathrm{CU}$ and $\mathrm{RB} 1$ reading is authorial.

2.39: it, ] Jackson writes in the manuscript: ..."he will rue the day it one of these mornings, when"... It looks like she wrote "rue the day", thought about it, crossed out "the day", and continued on with the sentence, forgetting to put in the comma. She most likely revised this sentence in her proofs.

3.9: Capitan, ] Jackson writes in the manuscript: ..."he said gently repulsing him in a fond tone gently repulsing him"... It looks like Jackson would have changed the punctuation in proofs to make the tone fonder, less harsh, by having fewer stops. She wrote "fond" and did not change her punctuation to match it in the manuscript. Likely she would have made this tonal change in a proof stage.

3.10: noise, ] The manuscript reads: ..."thou makest such a noise, the Senora can hear nothing but thy voice." The comma is essentially replacing that, and Jackson usually puts commas before that. CU and RB1 in most cases delete Jackson's commas before "that". Since this situation is similar enough to fall into this pattern of house style, I have kept Jackson's original punctuation.

3.11: Senora, ] The two variants in 3.11 both involve the same word; I have used the spelling from $\mathrm{CU}$ and $\mathrm{RB}$, but the punctuation that comes after it from the manuscript.

3.15: world ; 3.16: day; ; 3.17: another? ] In the manuscript, Jackson made changes to the Senora's tone in this passage. She started out wanting an "icy" tone, but later went back and wrote "sweet but icy" tone. Then, in her proof stage, she probably followed her pattern of revising punctuation for re-written manuscript passages, in order to better convey the revised tone. The sentence that Jackson originally wrote, the one in the "icy" tone, is: "If Senor Felipe listens to you, the poor boy Luigo will be cast out homeless on the world, some day, and what sort of a deed would that be for one Christian to do to another." Probably deciding that this original punctuation did not convey sweetness, Jackson deleted the interruptive clause and put in one of her characteristic semicolons before "and". Then she turned the clause after the semicolon into a question.

4.20: Ha, it ] In several instances, CU and RB1 insert exclamation marks for repeated words when they make up their own sentences, and especially when they convey sound: for example, "Ha" and "Ha". Because creating parallelism in exclamation marks seems to be a result of house style, I have kept Jackson's comma here. 
4.36: today, ] CU tends to take tone literally: since the character is said to be "asking", CU put in a question mark. Jackson's comma, however, better captures the "saucy" tone. Because this punctuation mark seems to be a CU idiosyncrasy, I have kept Jackson's punctuation.

5.14: mother; ] Although Jackson is often inconsistent even within her own general punctuation patterns, it is unusual for her to write sentences in which she does not give lists either with all the items separated by a punctuation mark, or none of them separated by a punctuation mark. She would not write a list with only some of the items separated by punctuation marks. In this case, she separates most items of the list with semicolons. Because she is so consistent in employing this method as one of her ways of writing lists, it is likely that she simply left out the semicolon here by accident. I have therefore kept the $\mathrm{CU}$ and $\mathrm{RB} 1$ semicolon here.

5.20: (tons of them, one would think) ] From the manuscript, it looks like Jackson wrote the clause "one would think" first, and then decided to enclose it in parentheses. In spite of ending the parentheses, she decided to continue it after all, with the clause "tons of them", enclosing it in its own parentheses. It also looks like she thought about adding even more, and so inserted the semicolon at the end of "them", but decided in the end not to. In her proofs, she switched the clauses, in a characteristic sentence structure change. She then probably took the opportunity to clean up her intentions for the parentheses, and remove the semicolon after "them", as she did not continue the sentence beyond that point.

5.22: kitchen ] RB has a comma after kitchen, coming before "or". Even though Jackson often puts a comma before "or" in a list of two things, the pattern is not consistent enough to warrant putting in a comma here on the strength of that piece of evidence alone.

5.23: cousins, ] This part of the sentence was heavily revised, making it a prime candidate for inclusion in Jackson's pattern of not revising the punctuation when she changes word choice. Since she shows that she did want commas separating the listed items earlier in this sentence, I have kept the CU and RB1 comma as being authorial. See note for 5.14 for a similar situation.

5.23: widows, ; 5.23: daughters ] Jackson uses commas in order to separate the different groups of relatives in this list. These variants present a challenge because it is difficult to tell here where she meant to distinguish one group of relatives from another. It changes the meaning to put the comma after "daughters", as RB1 and CU do, versus after "widows", as Jackson does. In the manuscript, "daughters" is more general and could mean daughters of anyone. For RB1 and CU, "daughters" is specific, meaning daughters of the brothers. There are no revisions or cancels made at or around this point in the manuscript, significantly lowering the possibility that Jackson went back to change the comma placement after "widows" in a proof stage, though the possibility still exists that did so. I have kept the manuscript's meaning and punctuation as being definitely authorial, and also as being the most likely product of Jackson's last intentions. 
5.24: cousins, ] Again, Jackson demonstrated a preference for separating the different relatives with commas, so I have taken this revision by RB1 to be within authorial intention.

5.24: stopping, ] For the previous two entries, RB1's comma after "sons" changes the meaning, making it seem that all of the relatives listed in the sentence were continually stopping at the house. In contrast, Jackson's comma after "stopping" makes it seem that only the sister's husbands or sons were stopping at the house. This revision by RB1 is similar to that made to 5.22 (see the accompanying note) concerning widows and daughters, making it general that all the previous relatives, not just the widows and daughters, had come to stay. Since Jackson meant the opposite in her manuscript, and since this situation with "stopping" is very similar to the situation with "widows", I have kept her original meaning here as well.

5.29: Senora, ; 5.29: Señora ] I have used the CU and RB spelling of the word, but the manuscript punctuation, turning "Senora," into "Señora,".

5.35: which ] While it is grammatically correct here to have the comma before which, Jackson does not make a habit of following this rule.

5.36: hard, ] CU and RB1 possibly misread this comma as a period, especially since it's followed by a capital letter. In any case, I have kept Jackson's original comma.

6.1: heart; ] Jackson writes in the manuscript: "The picture she saw there was one to thrill any mother's heart, and the Senora paused for a second on the threshold as it met her eye; enly and as it met here eye"... Not only does Jackson have a pattern of using a semicolon before conjunctive coordinators, but she has a habit of not changing her punctuation when she revises a sentence structure. Additionally, in her cancel she had a semicolon as her last piece of punctuation. For these reasons, I have decided that Jackson inserted the semicolon in her proof stage that RB1 uses, and kept it as being authorial.

6.13: true, ] Deciding which variant constituted authorial intention was difficult, as Jackson about equally does and does not add commas to mark dependent phrases. There is a cancel after "true", which implies the possibility that she would have meant to put a comma there. I have therefore decided that the likelihood of the CU and RB1 comma being authorial is higher than not, and kept it in the edition. The possibility is still strong, however, that Jackson did not intend the comma here, especially since CU and RB1 habitually put in commas to mark dependent clauses where Jackson has left them out.

6.14: not, ] This variant is tricky to read in the manuscript because after "not" Jackson has written a comma underneath of a dash. Does she mean a comma, or a dash, or a comma dash? RB1 and CU chose the comma. I have decided to retain it ultimately because Jackson's intentions in the manuscript are impossible to ascertain, but also because she both rarely uses em dashes and has a habit of putting commas before "that". 
6.14: Felipe ] In the manuscript, the sentence begins, "When Felipe," and continues with four lines of cancels before it gets to "once,". I decided to go with the lack of comma after Felipe because the extensive revisions after "Felipe" make it likely that Jackson went back to revise the punctuation here. However, the comma would not be out of character for Jackson to have here, and the possibility remains that she intended to leave it in.

6.16: mantle, ] Jackson has a strong enough pattern of either separating all items in a list with punctuation, or not separating any of them with punctuation, that the comma here is plausible. Since Jackson puts a comma between the short breeches and sombrero, it makes sense that she would want all the articles of clothing separated by commas.

6.27: times- ] This situation is unusual because, for once, Jackson has the comma dashes in her manuscript. Equally unusual, however, is that both RB1 and CU agree on the em dash. For this reason, it is quite likely that Jackson decided on the em dash during her proof stage. I have kept the em dash as being her authorial intention.

6.32: gallopped ] The Oxford English Dictionary does not show that Jackson's spelling was in use in the 19th century. It is possible that she simply spelled the word wrong. However, there is no evidence connected more specifically to Jackson to suggest that she would have wanted this word's spelling changed, so I have kept the spelling as being authorial.

7.1: perspicacity ] RB1 moves the comma from after "more", to after "perspicacity", which creates a more familiar sentence structure. However, it is not outside of Jackson's demonstrated style to have a comma in such a place, and there is no evidence to suggest that Jackson would have wanted the comma's placement changed.

7.13: Felipe ] The manuscript reads: "The handsome and vain Felipe, turned his handsome face toward his mother"... This is another instance in which Jackson has revised the wording of the sentence and has, more than likely, changed the punctuation to go along with the revised sentence structure later in a proof stage. Based on this theory, I have kept the CU and RB1 punctuation.

7.15: Indeed, ] The manuscript reads here: “Indeed mother my mother,". It looks plausible that this is another place that Jackson has not gone back to revise her punctuation, after cancelling part of a sentence. Additionally, having a one word dependent clause is within her punctuation style. For these reasons, I have kept the CU and RB1 comma.

8.25: triumph, ] In the manuscript the sentence is: ...this is is, to bre trimmph art triumph indeed;" Jackson was not clear how she wanted to structure this sentence and made several attempts at it before she found her way. Even though she tends to create comma splices, the comma is usually placed before the verb. I suspect that in this place Jackson did not put down the punctuation for the sentence that she wanted because she was so unsure while she wrote it. She likely returned to this place in proofs and revised her 
punctuation; I have therefore taken RB1's punctuation as being a reflection here of these corrected proofs.

8.29: degree. ] The manuscript reads: ... "to a great degree: they have manipulated"... Jackson did not go back and correct the punctuation after "degree" when she cancelled her word choices. Because she capitalizes "By" she clearly meant it to be the beginning of a new sentence. Hence, the mark after "degree" would need to be terminal. I have gone with RB1's punctuation as being authorial because it produces a terminal piece of punctuation.

8.28: sovereigns; ] It would be characteristic of Jackson to have a semicolon separating these two long independent clauses. Mostly, though, I have decided to take the CU and RB1 punctuation as authorial because Jackson has a cancel after "sovereigns". It is probable, given her tendencies in using semicolons, that she would have in her proofs written in a semicolon here.

\section{Chapter 26}

9.4: Thar! ; 1.4: Thar, ; 1.4: naow, ] For the three punctuation changes made in line 1.4, CU and RB1 have moved the location of Jackson's exclamation point. Jackson's sentence is thus: "Thar! Thar, naow," and it is changed to this: "Thar, thar, naow!" There is no reason to keep the changes made in the magazine and first edition, so I have kept Jackson's original punctuation here.

9.12: Felipe. ] Unusually, the manuscript and the magazine have agreed with each other, while the first edition contains the variant. Also unusually, the manuscript shows that Jackson has made a punctuation revision here, along with a word choice revision. She first wrote: "whispered Felipe," then wrote "breathed Felipe;". She turned the semicolon into a period during the round of corrections that she made with the darker inked pen: the period is in this darker ink, but the upper part of the semicolon is still present, in the lighter ink, making it confusing as to what mark she intended. The magazine read it as a period, while the first edition read it as the original semicolon. Because the period is in the darker ink, which is used for her later corrections of her manuscript, I have judged it to be her final intention and kept the period here.

9.21: afflicted ] Jackson makes a conflation here of Hebrews 36-38. Sometimes Roberts Brothers is okay with her method of sometimes not separating a list of three adjectives with commas, but here, perhaps thinking that conventional grammar was in order for a quotation of bible verses, they have added in the separating commas. I have kept Jackson's punctuation, as being authorial.

9.24: whispered, ] Jackson put an em dash after whispered in the manuscript. Usually, $\mathrm{CU}$ and RB have no issue with em dashes, and it is unusual for Jackson to set off dialogue using one. She does generally have a comma setting off dialogue - although I would not make a punctuation judgment based on just this pattern alone. These two 
patterns together, however, indicate the strong possibility of Jackson's revising the em dash in the manuscript to a comma in the proofs. Therefore, I have used the comma here instead of the em dash.

10.2: time. ] CU tends to take sentence structures that imply exclamations and questions literally. The sentence as Jackson and RB1 have it is: How often he had seen it in the olden time. Beginning the sentence with "how" implies an exclamation, hence CU has added an exclamation mark; this punctuation mark implies an excitement or anger inherent in the statement. The lack of an exclamation mark as Jackson has it, however, softens the sentence's tone into a nostalgic melancholy and gives a very different picture of Felipe's relationship with his mother. Felipe in this sentence harbors no resentment or anger towards his mother; just regret.

10.6: then, ] Jackson writes in the manuscript: "The eyes dilated, then, filled"... When she inserted "then" she was also conscious of what she wanted punctuation-wise. In general, when she adds words, versus cancelling a part of a sentence and then re-writing it, she is more careful to put in the punctuation she wants. I have hence kept her original punctuation.

10.7: Felipe, ] It is difficult to tell whether Jackson wanted this change or not. Even though RB1 does not tend to add exclamation marks to the prose in the way that CU does, it tends to prefer parallel exclamation marks. For example, in chapter one they changed "Ha! ha," into "Ha! Ha!". In this case, exclamation marks in the following sentences are used to make dramatic a transformation of Ramona's mindset, from despair to hope: "Not only her child to live for, but to "take care of Felipe"! Ramona would not die!" The comma after Felipe, as it originally was in the manuscript, implied a resignation and a passivity on Ramona's part, especially since it comes before the word "sighed". The change to an exclamation mark, however, changes this resignation into hope, a tone that better matches the rest of this passage. It is quite possible that Jackson meant for this change to happen. However, it is also possible that she meant the comma to represent Ramona automatically saying the words "dear Felipe" while she was internally occupied with the uplift in her emotions. Both interpretations work, but offer subtly different readings of the passage and of how Ramona's internal life relates to her eternal one. I have left the manuscript's comma because it could go either way. Keeping the mark I know that Jackson preferred at one point is the only way to legitimately punctuate this word.

10.10: life; - ] Both CU and RB1 tend to delete Jackson's more unusual punctuation marks, such as the semicolon dash. For this reason, though I usually take RB1's comma dashes as authorial, I have kept Jackson's semicolon dash here. It appears that CU wanted to preserve something of Jackson's intended punctuation, and so dropped the semicolon; then RB1, per its usual pattern, probably corrected the CU em dash into the comma dash.

10.27: South, ] While it is in character for Jackson to have a semicolon in front of a coordinating conjunction like "and", in this case the semicolon looks like an edit made by $\mathrm{CU}$ and RB1. In the manuscript, Jackson writes: "to take her to his home, and then he in 
the South, and then he"... Her revision demonstrates her surety about having a comma in front of "and then he". CU and RB1 probably inserted the semicolon in order to give a wider separation between the first half of the sentence, which is about Felipe taking care of his sister, and the second half, which is about his murderous feelings towards Alessandro's killer.

10.28: hanged, ] Jackson's authorial intention is ambiguous here. Unusually, RB1 has written a comma dash not in a place where CU has written an em dash. My theory that CU leaves out the comma in front of dashes whenever Jackson has a comma dash in her corrected proofs hangs on the pattern that RB1 almost always corrects $\mathrm{CU}$ and has the full comma dash. This theory does not apply here, and so it is much less likely that the RB1 comma dash is authorial. Complicating matters, though, is that Jackson has a pattern of inserting comma dashes between repeating words, such as in a place like this between "hanged" and "yes hanged." It is possible that CU either made a mistake in putting the semicolon here, or had some unknown conscious reason for leaving out the em dash. However, it is equally possible that RB1 picked up on this pattern of Jackson's for comma dashes, and obligingly followed it in this instance when Jackson failed to. Because these alternatives are equally plausible, I have fallen back on the original manuscript punctuation, as being verifiably authorial.

10.30: Señor ; 2.30: Senor, ] For this variant, as well as the previous variant, I have chosen to keep CU and RB iteration of Señor, which includes the Spanish accent. However, I have also chosen to keep the manuscript comma after this word. In other words, the spelling of the word is from $\mathrm{CU}$ and $\mathrm{RB}$, and the punctuation is from the manuscript.

10.30: Farrar ] Jackson changed this character name from Farrell to Farrar in the middle of chapter 26, but missed revising the name in some places. This forgetfulness was a habit of hers: in The Hunter Cats of Connorloa, she changed a character name from Wilson to George, but in the earlier parts of the manuscript forgot to make the change. She either went back and changed the name to Farrar in her proofs, or the editors did so for her.

10.31: of, ; 2.32: judges; ; 2.32: bullet, ;2.32: that ] These variants involve some unusual punctuation revisions. The sentence in the manuscript is (bold is mine): "The rope he had small fear of; for well he knew the temper of San Diego County juries and judges, but the bullet! That was another thing"... The revised sentence in CU and RB is: "The rope he had small fear of, for well he knew the temper of San Diego County juries and judges; but the bullet, that was another thing".... The semicolon after "of" and the comma after "judges" were switched. The resulting construction is characteristic of Jackson's style, with a semicolon before the coordinating conjunction "but." The exclamation point after "bullet" has been exchanged with a comma. Since CU has a tendency of preferring exclamation points in clearly exclamatory passages, it is significant that here they do not retain the exclamation point. Furthermore, it is characteristic of Jackson to have long sentences with both semicolons and colons. Based on these factors, I have decided that the revision of this sentence's punctuation is authorial, done in a proof stage. 
11.11: investigated, ] Jackson writes this clause in the manuscript: "if the case were brought ${ }^{\text {up }}$ a second time, ${ }^{\text {and }}$ minutely investigated would be most unfortunate". It appears that Jackson first thought to list three circumstances in this clause and so put a comma between "time" and "minutely", but then decided to just keep the two items, and so inserted "and". It is likely that this clause is another place in which Jackson has made a sentence structure revision and not changed the punctuation to go along with it. For this reason, I have kept $\mathrm{CU}$ and $\mathrm{RB} 1$ punctuation.

11.21: not; ] Jackson's punctuation in the manuscript is ambiguous here: she has either put a semicolon or a comma dash after "not". Because she so rarely uses comma dashes in her manuscript, the probability was in the favor of it being a messy semicolon. I therefore keep her original semicolon here, as a semicolon, though the possibility remains still that she wrote a comma dash.

11.22: morning ] In the manuscript, Jackson inserted "one morning" into the sentence after she had written it out: "Felipe walked into Judge Wells's office one morning to make inquiries"... It is quite possible that she would have wanted the clause "one morning" to be punctuated with commas. However, often she does not mark off dependent clauses in the middle of sentences. Weighing her two tendencies, of not revising punctuation when she changes sentence structure in manuscript and not marking dependent clauses, I have judged it more likely that she would not have wanted commas here.

11.24: Judge ; 3.24: Judge, ] For these variants, I have taken the capitalization from the manuscript and $\mathrm{CU}$, and the comma from $\mathrm{CU}$ and $\mathrm{RB} 1$. I have taken the comma because in the manuscript Jackson made a word choice revision that changed the sentence structure, but did not put in punctuation to mark that changed structure. She writes: ..."the Judge 's own life-taking down his books, read to Felipe"... It is within Jackson's demonstrated style to have a comma here, so I have taken the CU and RB1 punctuation mark as being Jackson's.

11.25: say, ] Jackson has no punctuation mark after "say" in the manuscript. She does usually set off dialogue with a comma, so I have taken the CU and RB1 comma as authorial.

11.26: at any rate, "her ] There is no evidence pointing firmly as to whether or not this change was authorial. It is the only revision of where a piece of dialogue begins that I have seen, and so have no basis with which to compare it. For lack of a reason to change it, I have left the manuscript's original placement of the quotation marks.

11.32: fled ] It is odd that Jackson would put a comma here, directly after a verb. In her manuscript, she writes: "When Aunt Ri heard that Farrar had fled, the country the country, she"... It appears that Jackson was not sure what she wanted in this sentence. For these reasons, I have gone with the $\mathrm{CU}$ and $\mathrm{RB} 1$ comma. 
12.5: arter; ] Jackson clearly wrote the sentence this way in the manuscript, with the semicolon after "arter" instead of "dies": "Thet Injun he murdered'll foller him, night 'n' day, till he dies ' $n$ ' long arter; he'll wish he-could die wuz dead, afore he does die." With the semicolon here, the sentence does not make sense. It says that Alessandro's ghost would follow Farrar until he dies, and that after Farrar dies he will wish that he's dead. It is possible that Jackson moved the semicolon in a proof stage, or if an editor at the Christian Union changed it, it is likely that she would agree with the edit.

12.8: there ] Jackson is irregular with Aunt Ri's dialect in several places. CU and RB1 correct these deviations: changing there into thar, Indians into Injuns, and so on. It is quite possible that Jackson made mistakes in these places, that she did want Aunt Ri's dialect to be regular. However, there is no concrete evidence that legitimizes this possibility, so I have left the manuscript inconsistencies in.

12.16: sed he, ] Jackson did not put a punctuation mark after "he" in the manuscript. Since she so often uses commas to set off dialogue, I have gone with the CU and RB1 punctuation here.

12.20: hain't; ] This punctuation change is ambiguous as to whether or not it could be authorial. It is unusual for CU and RB1 to change an exclamation mark in this way. The change is not consistent with the house style patterns I have observed. Additionally, Jackson tends to use semicolons before coordinating conjunctions, though this is a lesser factor since she does not do so for a large minority of coordinating conjunctions. It seems more possible, based on these patterns, that Jackson changed the exclamation mark in the proofs, than that $\mathrm{CU}$ and RB1 changed the punctuation on their own. Because CU often makes mistakes in setting type, and because Jackson would be less likely use a comma here, I have gone with the RB1 semicolon.

12.25: it!" ] Jackson does not have quotation marks at the end of this piece of dialogue. Because she showed a preference for enclosing this section of reported dialogue in double apostrophes, I have put them in here, instead of using the single apostrophe of CU and RB1.

12.27: him, ] While Jackson did use the comma dashes earlier on this page to show Aunt $\mathrm{Ri}$ interrupting herself, as Aunt Ri does in this use of comma dashes, it is odd for Jackson to set off dialogue using a comma dash. Usually she employs commas for this purpose. It is possible that Jackson would have meant the first comma dash to be there (the variant listed in 4.29), but wanted a comma for this variant, instead of a second comma dash. Since RB1 does not have a paragraph break after this variant, the comma dash does not look unusual or have an unusual abruptness in the first edition. Jackson, however, does have a paragraph break here, and I have decided to retain all of her paragraph breaks for the critical edition (see the chart collating paragraph breaks). If I used the RB1 comma dash, combined with the paragraph break, it would create an unusually large caesura in Jackson's prose and add perhaps unwanted significance to the next lines. For this reason, I have not retained the comma dash in this place, but readers should be aware that it is a possibility that Jackson meant for the comma dash to be here. 
12.35: listened ] Jackson has a long cancelled passage after this word, so it is more than likely that she followed her pattern of not revising punctuation when she revises sentence structure. I have therefore kept the CU and RB1 punctuation here.

12.40: remains — ; 5.1: fossilized — ; 4.40: nature ] Jackson has extensive revisions after "nature" in the manuscript. She writes: ..."underneath the exterior crust of the most

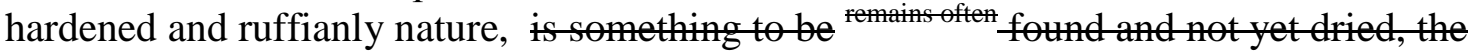
often remains, its forms not quite fossilized, the shatter youth s the childs old the this an age, when the full of the devout customs"... With a characteristic comma splice, she wrote a comma after "nature" in front of "is," but her proof revisions to the rest of the sentence demonstrate that, in the end, she probably did not mean for the comma to be there. CU and RB1 surprisingly agree on the placement of two em dashes, after "remains" and after "fossilized". The revised sentence reads: "underneath the exterior crust of the most hardened and ruffianly nature often remains - its forms not yet quite fossilized - a realm full of the devout customs". I have taken these em dashes to be authorial (see the discussion on em dashes in the textual note). Because it would be uncharacteristic of Jackson to have a phrase interrupting her sentence right before using an em dash, I have judged that she took the comma out after "nature" in her proof stage. I have determined that all three variants, therefore, are products of Jackson's revisions.

13.1: customs, ] Jackson sometimes separates lists using commas and sometimes does not; it is one or the other. She writes in the manuscript: ..."customs Calivinistic doctrines, religious influences, which the boy knew"... In this case, because she did use commas to separate "doctrines" and "religious influences", I have used the CU and RB comma between "customs" and "doctrines".

13.6: speech, ] In her manuscript, Jackson writes: ..."he is thrown into all manner of confusions, and inconsistencies of speech feeling and speech, between by this clashing of the old and new man within him." Conceivably, Jackson did not cancel the comma after "speech" when she cancelled "between", going back in the proofs later to cancel it. However, Jackson does not have a consistent pattern of how she uses commas before starting a clause with "by". I have not made a change from the manuscript here because there is no distinct evidence either for or against the comma.

13.11: so. I ] Both CU and RB1 have added the exclamation mark here, following their pattern of creating parallel exclamation marks for words or phrases that repeat. Since Jackson wrote, "That's so Aunt Ri!" they evidently decided that the next "That's so" needed an exclamation mark as well.

13.13: different. ] In the manuscript, Jackson clearly capitalized the word after "different". She writes: "this horse stealin' business is different; that's 'T'ain't murder". She wrote the semicolon and "that's", but then changed her mind and decided to end the sentence. Thus, she capitalized the next word and then, most likely, in her proofs corrected the semicolon into a period. 
13.18: crazy. ] Jackson has no punctuation mark here, but she does clearly capitalize the word after "crazy," demonstrating an intention for a terminal piece of punctuation. I have therefore put in the CU and RB1 period.

13.32: tireless, ] In her manuscript, Jackson writes: ... "she was tirelessly eloquent. It was and her language speech eloquent"... Jackson likely went back in a proof stage to add the comma in front of "and". It is furthermore a characteristic construction of hers to separate two descriptive items with a comma in front of "and".

13.35: hearted ] Jackson writes in the manuscript: ..."in the presence of these simple hearted, and friendliness"... She put the comma after "hearted" with a different sentence structure in mind; most likely it would have been her characteristic construction of two descriptive words separated by a comma in front of "and." She most likely went over this place in her proofs and cancelled this comma, left over from a rejected sentence structure.

14.1: took care on, ] The evidence is not conclusive either for or against this comma. In the manuscript, Jackson writes: "The sick allers ez took care on, in those villages among them, they sed,". The comma works with the original sentence structure, before "in", and in the new sentence structure, before "among". There is no grammatical reason, within Jackson's style, for Jackson to remove it, but it is possible that in revisions she decided to do so. For lack of a strong reason to do otherwise, I have gone with the last authorial intention that I know existed and kept the punctuation from the manuscript.

14.5: tew; ] Essentially, a semicolon and a comma were switched in this group of sentences. The manuscript reads: ..."pears like there cuddn't nobody b'leeve ennythin' 'n' this world 'thought seein' 't their selves; I wuz thet way tew. I allow I hain't got not call ter talk; but"... The first edition switches the semicolon after "selves" with the period after "tew". There is no grammatical reason to do so, the change is not consistent with the patterns of house style that I have observed, and it is within the character of Jackson's style. I therefore think it most likely that Jackson made this change in a proof stage.

14.13: Ramona, ] Jackson writes in the manuscript: "Ramona had been as Alessandro's wife had wife of Alessandro, had been as their sister"... It is probable that Jackson would have gone back to put in a comma after "Ramona" in a proof phase, especially since she revised the structure of the sentence here.

14.25: girlhood, ] The manuscript is ambiguous here as to whether Jackson intended a comma or not. She writes: ..."which had characterized her girlhøød , and kept her". Above the cancelled words and the un-cancelled comma, she writes, "daily life in her girlhood and kept", which makes the complete clause "which had characterized her daily life in her girlhood and kept". However, that she could have meant for the un-cancelled comma to go in front of "and," especially as she had an "and" after it in the first place. I keep the CU and RB1 punctuation because this is in my view the strongest possibility. 
14.31: said, ] Jackson has no punctuation mark here. The comma inserted here in CU and RB1 is characteristic of Jackson's style, as she so often uses commas to set off dialogue. I have, therefore, kept it as being more than likely authorial.

16.15: yeow, ] Jackson has no punctuation mark here at the end of this piece of dialogue, where she normally would have. Having a comma here would be within her characteristic writing, so I have left in the $\mathrm{CU}$ and RB1 comma for a lack of having an alternative to consider.

17.2: thet. ] It is unusual for CU and RB1 both to change a question mark, and to agree on what punctuation mark should be put in its place. Furthermore, I have seen no patterns indicating house style concerning the placement of question marks. I have decided to take the period, then, as an authorial revision of Aunt Ri's tone.

17.13: Injuns. ] This is the second question mark changed in Aunt Ri's dialogue during her conversation with the Indian Agent. Again, because it is rare for a question mark to be changed and because there is no indication of a house style concerning punctuation marks, it is likely that Jackson went back through and changed Aunt Ri's feelings towards the Indian Agent.

17.17: Agent ; 9.17: Agent, ] Although I am not regularizing Jackson's capitalization or spelling in general, because she capitalizes "Agent" in every single other instance in this chapter, I judge the implication is that she would have wanted it capitalized here as well. She is usually much more varied in her non-grammatical capitalization. The comma after this word is from the manuscript and RB1.

17.24: say_ - J Jackson is ambiguous here in her manuscript. After Aunt Ri finishes speaking, she writes two crosses: "I'm free ter say," + + Aunt Ri paused;"... What the purpose is of these crosses I do not know. Possibly they indicate dashes, but in several other places in the manuscript they do not correspond with a change of punctuation in $\mathrm{CU}$ or RB1, that is, they are clearly not dashes. I have used the CU and RB1 em dash here, though not without hesitation.

17.37: good naturedly ] Jackson possibly wrote "good naturedly" as one word in the manuscript. I decided it was most likely that she had a long serif on the $n$, making it look as though it was one word, but the possibility remains.

18.22: unreal? ] This punctuation change from an exclamation mark to a question mark I believe to be Jackson's, though the possibility remains that CU and RB1 changed it to a question mark because the sentence is structured like a question. However, RB1 is not prone to putting in question marks whenever a sentence sounds like a question. Although $\mathrm{CU}$ does have this tendency, that they agree makes it more likely that Jackson herself made the change in proofs.

18.16: himself, ] Unusually, the manuscript and CU agree on the punctuation here. In most other instances of Jackson changing punctuation into a comma dash, CU leaves out 
the comma. Here, it looks as though Roberts Brothers put in the comma dash on their own. It is nevertheless possible that Jackson changed the comma into a comma dash at a later stage. However, I think it most likely, based on the overall pattern of em dash changes, that Jackson did not put in the dash here. I have thus kept the manuscript and CU comma.

18.29: not, ] In this exchange between Ramona and Felipe, the exclamation mark and the comma are switched. Originally, Jackson had: "That is more than human power can do," said Felipe. "I think not!" replied Ramona." Because this change is not consistent with house style, because CU and RB1 agree, and because Jackson as per my theory revised her proof for tonal changes, I have taken these punctuation changes as authorial.

19.19: "Humph!" ] Jackson did not put a punctuation mark here. She normally does when finishing a piece of dialogue, so I have taken the CU and RB1 explanation mark to be authorial.

19.22: man! And ] In this passage, an explanation mark and a semicolon, for "else" and "man" have been switched. Originally, it read: "We'd never have seen the Senorita back here else! I can tell you that, man; and for my part..." It is more possible that Jackson made this change, for $\mathrm{CU}$ and RB1 editorial changes have more to do with proper grammar and house style patterns than with switching punctuation marks to edit tone.

19.23: Señorita ; 11.23: Senorita, ] I have used the spelling of Señorita from CU and $\mathrm{RB} 1$, but the punctuation from the manuscript.

19.23: ashes! ] It is more likely that Jackson made this change to an explanation mark, as the change does not fit any demonstrated patterns of house style.

20.10: Can's ] The lack of a possessive here is probably an RB1 compositor error. Jackson clearly meant a possessive. I have used the CU here because it includes the apostrophe before the s.

20.11: Señorita ; 12.11: Senorita, ] I use the spelling of this word from CU and RB1, but the comma after it from the manuscript.

20.16: child, ] Jackson writes in the manuscript: "But how differently had it come! Not Felipe's child; Ramona's; the poor outeast as she proudly had pictured;" Because she heavily revised this sentence's structure, likely she went back over it in her proof stage to fix the punctuation. That she generally uses commas before "as" makes it further plausible that this change is authorial.

20.33: things; ] Jackson does not have a punctuation mark after "things" in the manuscript. Based on her usual style of punctuation, she would have separated these two clauses with some kind of punctuation mark. In the absence of any alternatives, then, I have taken the semicolon to be authorial. 
21.26: Barbara? ] Since Jackson revised the question mark after "Church" into a comma dash (see the textual note for a discussion on comma dashes), it is logical that she would defer the question mark until the new end of the sentence. The possibility that she wanted a period after "Barbara" still remains, though I believe it to be a small one.

21.35: sunny - ] CU and RB1 in general do not change Jackson's em dashes. There is a large possibility that Jackson herself went back to change this dash into a comma.

However, there is no further evidence to support this possibility, so I have left it in as the last reasonably verifiable record of her intention.

24.28: her. Could ] Jackson has extensive revisions after "her". These revisions show that Jackson was experimenting with a variety of sentence structures. She writes: "loved her; She and shewith all that lived in her the love she was capable of feeling, had been Felipe's could-she refuse to give Felipe happiness". It is likely here that Jackson went back to revise the semicolon after "her" in her proofs.

25.13: Señor ; 17.13: Senor;- - ] I have taken the spelling of Señor from CU and RB1, but the punctuation after it from the manuscript. 


\section{Collation of Paragraph Breaks}

To indicate paragraph breaks, I give the first few words of the new line, along with $n p$ for "new paragraph" or $s p$ for "same paragraph", to indicate that the line either marks the beginning of a new paragraph, or simply continues a paragraph with no break. For example, in the first variant, 1.38, "There were" is not a new paragraph in the manuscript, so I have marked it $s p$ for same paragraph. Because it is indented to create a new paragraph in CU and RB1, it is marked $n p$. In variant 2.6, Jackson indents the line beginning with "God knows" to create a new paragraph, so $n p$, while CU and RB1 keep "God knows" as part of an existing paragraph, so sp. I have kept all of the manuscript paragraph breaks for the critical edition.

\section{Chapter 1}

$\begin{array}{llll} & \mathrm{M} & \mathrm{CU} & \mathrm{RB} 1 \\ \text { 2.1: "There were } & s p & n p & n p \\ \text { 2.9: "God knows } & n p & s p & s p \\ \text { 2.16: "Beg your } & n p & s p & s p \\ \text { 2.19: "It is not } & n p & s p & s p \\ \text { 2.37: Encouraged by } & s p & n p & n p \\ \text { 3.7: His eyes } & n p & s p & s p \\ \text { 5.38: "Poor things } & n p & s p & s p \\ \text { 6.5: "Good morning } & n p & s p & s p \\ \text { 6.13: And it } & n p & s p & s p \\ \text { 6.22: "I will not } & n p & s p & s p \\ \text { 6.29: "Wear them } & n p & s p & s p \\ \text { 7.15: "Indeed } & n p & s p & s p\end{array}$

\section{Chapter 26}

$\begin{array}{llll} & \mathrm{M} & \mathrm{CU} & \mathrm{RB} 1 \\ \text { 9.11: "Felipe?" } & n p & s p & s p \\ \text { 9.28: Pointing } & n p & s p & s p \\ \text { 9.29: "Alessandro." } & n p & s p & s p \\ \text { 9.30: Felipe } & s p & n p & n p \\ \text { 9.32: "Naow, } & n p & s p & s p \\ \text { 10.4: "I am alone } & n p & s p & s p \\ \text { 10.7: "Dear Felipe } & n p & s p & s p \\ \text { 11.1: "Señor } & n p & s p & s p\end{array}$


11.28: "She of whom $n p$

12.17: 'Jake'— n $\quad n$

12.19: "Why np

12.20: "Yes $n p$

12.23: Them's $n p$

12.25: Wall $n p$

12.28: 'Wal! np

12.29: 'Yes $n p$

12.31: Yer see $\quad n p$

13.17: "I hain't $n p$

13.36: "I'll never $\quad n p$

14.20: "Sister! $n p$

14.31: "I allow $n p$

15.25: I larned $\quad n p$

15.29: But fur $n p$

16.29: "What's thet $n p$

17.12: "Ef it $n p$

17.25: Aunt Ri $\quad n p$

18.20: "Dearest $\quad n p$

18.34: When on $\quad n p$

18.38: I hope $n p$

20.33: "Oh yes $n p$

21.5: "You haven't $n p$

21.23: "Dear Felipe $n p$

21.29: He found $n p$

21.37: "Felipe! $\quad n p$

22.18: "She will $n p$

22.32: "Dear Felipe! $\quad n p$

22.33: "Ramona! $\quad n p$

22.33: The moonlight $s p$

22.36: "Felipe! $\quad n p$

23.7: "Dear Felipe $\quad n p$

23.13: "I have $n p$

23.16: You could $n p$

23.31: "I will

$n p$

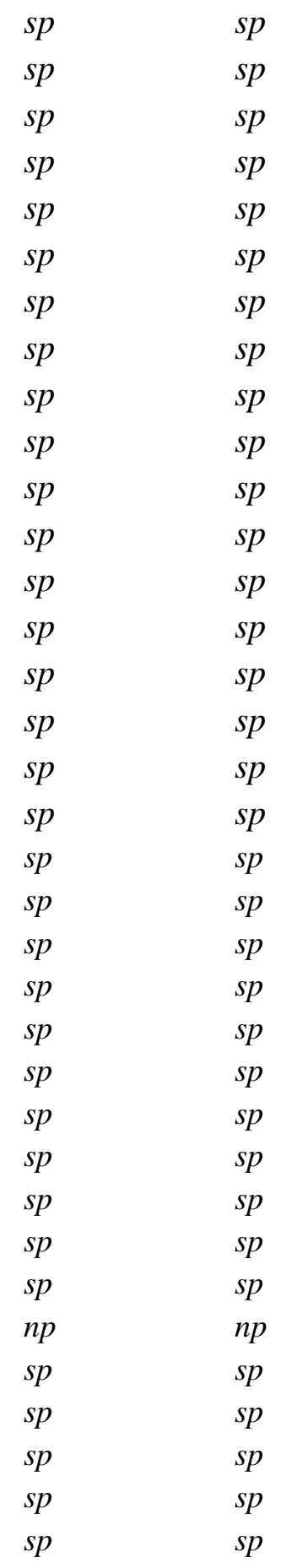




\section{APPENDIX A}

\section{Ramona Editions}

For these citations, I use Jackson's name as it appears on the title pages. In some copies, for example in the 1900 second editions, "Helen Jackson" is the author name on the binding, but "Helen Hunt Jackson" is the author name on the title page. By using the title page name, I show when the name "Helen Hunt Jackson" began to be used, a name that Jackson never went by during her lifetime.

There have been editions of Ramona printed throughout the world, and it has been translated into many different languages. For the purposes of this project, which includes a focus on the United States reception of the novel (see the historical commentary), I examined United States editions. I have not included the print-on-demand options for buying Ramona, as they are reprints of previous copies.

The purpose of this list is not to definitively assign which copies belong to each edition, as I was not able to study many copies that could possibly be different editions themselves. The purpose is to show the sources I examined, the different settings of editions that I was able to trace, the relationships between different editions, and to give a general idea of the United States publication history of Ramona since 1884. For a detailed description of these editions, please see Appendix B. I have listed the United States editions that I was not able to personally examine, but saw mentions of, after my list of the copies that I did study.

List of Ramona editions examined, 1884-2014

\section{FIRST EDITION}

Jackson, Helen. Ramona. A Story. Boston: Roberts Brothers, 1884.

-.1885 .

Jackson, Helen. Ramona. A Story. With appendix, "Ramona's Home: A Visit to the Camulos Ranch, and to the Scenes Described by 'H. H." By Edwards Roberts. Woodblock illustrations. Boston: Roberts Brothers, 1886.

$-.1887$.

-. 1889 .

$-.1890$.

-. 1894.

—. 1896.

-. 1897. 
—. Boston: Little, Brown and Company, 1898.

-. 1902.

-. 1910.

-. 1912.

\section{SECOND EDITION}

Jackson, Helen Hunt. Ramona. A Story. Introduction by Susan Coolidge, Illustrations by Henry Sandham, "Notes of Ramona Illustrations" by Henry Sandham. Monterey ed. 2 vols. Boston: Little, Brown and Company, 1900.

—. Edition de Luxe ed. 2 vols. Boston: Little, Brown and Company, 1900.

—. Pasadena ed. Boston: Little, Brown and Company, 1900.

Jackson, Helen. Ramona. A Story. Introduction by A. C. Vroman, illustrations from original photographs by A. C. Vroman and decorative headings from drawings by Henry Sandham. Boston: Little, Brown and Company, 1913.

$-.1915$.

$-.1920$.

-. 1922.

\section{THIRD EDITION}

Jackson, Helen. Ramona. A Story. With appendix, "Ramona's Home: A Visit to the Camulos Ranch, and to the Scenes Described by H. H." By Edwards Roberts. No illustrations. Boston: Little, Brown and Company, 1914.

- With appendix, "Ramona's Home: A Visit to the Camulos Ranch, and to the Scenes Described by H. H.'” By Edwards Roberts. Woodblock Illustrations. Includes photographic frontispiece from Ramona movie. Boston: Little, Brown and Company, 1917.

—. With appendix, "Ramona's Home: A Visit to the Camulos Ranch, and to the Scenes Described by H. H.”' By Edwards Roberts. No Illustrations. Includes 
photographic frontispiece from Ramona movie. Boston: Little, Brown and Company, 1924.

- With appendix, "Ramona's Home: A Visit to the Camulos Ranch, and to the Scenes Described by H. H.'” By Edwards Roberts. Woodblock Illustrations. Includes photographic frontispiece from Ramona movie. Boston: Little, Brown and Company, 1926.

Jackson, Helen. Ramona. A Story. Includes photographic frontispiece from Ramona movie. Boston: Little, Brown and Company, 1927.

\section{FOURTH EDITION}

Jackson, Helen. Ramona. A Story. Illustrations by Herbert Morton Stoops. New York: Junior Literary Guild, 1932.

Jackson, Helen. Ramona. A Story. Illustrations by Herbert Morton Stoops. Boston: Little, Brown and Company, 1937.

-. 1939.

\section{FIFTH EDITION}

Jackson, Helen Hunt. Ramona. Boston: Grosset and Dunlap, 1934.

-. 1936.

— . Introduction by May Lamberton Becker. Illustrations by N. C. Wyeth. Little, Brown and Company, 1939.

—. Introduction by May Lamberton Becker. Illustrations by N. C. Wyeth. Little, Brown and Company, 1941.

Jackson, Helen Hunt. Ramona. New York: Triangle Books, 1941.

— . Introduction by May Lamberton Becker. Illustrations by N. C. Wyeth. Little, Brown and Company, 1942.

— . Introduction by May Lamberton Becker. Illustrations by N. C. Wyeth. Little, Brown and Company, 1944. 
— . Introduction by May Lamberton Becker. Illustrations by N. C. Wyeth. Little, Brown and Company, 1951.

Jackson, Helen Hunt. Ramona. Boston: Grosset and Dunlap, 1961.

\section{SIXTH EDITION}

Jackson, Helen Hunt. Ramona. Art-Type Edition. New York: Books Inc., 1944.

\section{SEVENTH EDITION}

Jackson, Helen Hunt. Ramona. Limited Editions Club Edition. Introduction by J. Frank Dobie. Illustrations by Everett Gee Jackson. Los Angeles: Plantin Press for the Limited Editions Club, 1959.

\section{EIGHTH EDITION}

Jackson, Helen Hunt. Ramona. New York: Avon Books, 1970.

\section{NINTH EDITION}

Jackson, Helen Hunt. Ramona. New York: Pinnacle Books, $1981 .^{52}$

\section{TENTH EDITION}

Jackson, Helen Hunt. Ramona. Introduction by Michael Dorris. New York: Signet Classic, 1988.

- Introduction by Michael Dorris. Afterward by Valerie Sherer Mathes. New York: Signet Classic, 2002.

$-.2006$.

\section{ELEVENTH EDITION}

\footnotetext{
${ }^{52}$ Pinnacle books sold a sequel to Ramona as well: Myers, Virginia. Ramona's Daughter. New York:
} Pinnacle Books, 1981. 
Jackson, Helen Hunt. The Annotated Ramona. Introduction and Notes by Antoinette May. San Carlos: Wide World Publishing, 1989.

\section{TWELFTH EDITION}

Jackson, Helen Hunt. Ramona. Siobhan Senier, ed. Buffalo: Broadview Press, 2008.

Other Ramona Copies, not examined ${ }^{53}$

Jackson, Helen Hunt. Ramona. Gift edition. Illustrations by Herbert M. Stoops. Boston: Little, Brow and Company, 1932.

— . Abridged by Nora Kramer. New York: Scholastic Book Services, 1973.

—. New York: Lighthouse Press. 1976.

${ }^{53}$ DeLyser, Ramona Memories, 226. These copies are listed in DeLyser's bibliography of Ramona editions. 


\section{APPENDIX B \\ Descriptive List of Editions, 1884-2014}

Ramona has never been out of print, although publication since the 1990's has been driven more by scholarly interest than by its popularity with general readers. There has been work done to catalogue all of these different editions. DeLyser's book usefully includes a bibliography of all the editions of Ramona that the author was able to find; it includes mostly United States editions, but also lists some British and Canadian editions, as well as some audio book renditions. This enumerative bibliography is the only one that I have been able to find for Ramona specifically. Ruth Odell's biography of Jackson, mentioned in G. Thomas Tanselle's Guide to the Study of United States Imprints ${ }^{54}$, includes a comprehensive enumerative bibliography of all of Jackson's published and unpublished writing. ${ }^{55}$ Special Collections at the Tutt Library of Colorado College aims to collect all of the different editions of Ramona, in all languages, and is a highly useful resource for the study of this book's history.

Michele Moylan demonstrates why examining the changing book design of Ramona is important in understanding how publishers have interpreted audiences, and how audiences in turn have had their readings affected by the book's design. In other words, how does judging the book by its cover shape interpretation? She categorizes the book's design over its entire publication history into six different audience reactions. For example, she posits that audiences reading 1900 editions are influenced to read Ramona as being Spanish rather than Indian because of the illustrations, which have Ramona in

\footnotetext{
${ }^{54}$ Tanselle, G. Thomas. Guide to the Study of United States Imprints. 2 vols. (Cambridge: Belknap Press of Harvard University Press, 1971), 1: 223.

${ }^{55}$ Odell, Helen Hunt Jackson, 249-314.
} 
Spanish dress and heavily emphasize Catholic and Gothic symbols. ${ }^{56}$ Her premise is intriguing, and it could be taken even further by including analysis on more editions, including an examination of its evolving dust jackets.

Part of my goal in compiling this book history was to pave a broader way for more work like Moylan's to be done by systematically giving more detail on each edition of Ramona. Furthermore, studying the text in its material form will shed new light on its paradoxical reception history. For the purposes of this critical edition, I wanted to examine how the material text has perhaps changed or enhanced Jackson's meaning. Additionally, one can see how a critical edition would depart from the goals of previous editions of the book.

Description of Editions

The first edition was printed in 1884 , almost immediately after the serialization ended. Roberts Brothers was probably hoping for Christmas sales and released the book as a gift edition, complete with a book box. The book came in one volume and was not illustrated. It was an octavo that contained 31 gatherings; the advertisements were not inserted later, separately, by a binder, but were included in the last gathering. When a book box was not included, it came inside of a simple paper, creamy dust jacket. Its design, in red ink, mirrored the front cover, which had the title, author, and three artichoke flowers in gilt. Thomas Niles, the editor of Roberts Brothers, was invested in

\footnotetext{
${ }^{56}$ Moylan, Michelle. "Materiality as Performance: The Forming of Helen Hunt Jackson's Ramona," in Reading Books: Essays on the Material Text and Literature in America. Michelle Moylan and Lane Stiles, eds. (Amherst: University of Massachusetts Press, 1996), 230
} 
book design, and it is likely that he himself created the design for the binding. ${ }^{57}$ The book could have been had in binding cloths of a variety of colors: dark green, medium red, and medium yellow are three that I have seen.

The advertisements at the back of the book are the same, and from the same plates, in the printings through 1885 and some of 1886. In 1886, most likely in late April or May, Roberts Brothers added a gathering, making the book 32 gatherings long. They did so in order to add Edwards Roberts essay entitled "Ramona's Home: A Visit to the Camulos Ranch, and to the Scenes Described by 'H. H.,"' the original of which appeared in the San Francisco Chronicle on April 17, 1886. For the book, it was illustrated using woodblock prints. Niles usually preferred to use woodblock prints for illustrations, over working with electrotypes. ${ }^{58}$ The rest of gathering 32 was given to advertisements.

In 1898, Roberts Brothers, which had been floundering since Niles's death, was purchased by Little, Brown and Company. The firm had just recently begun to expand its catalogue towards fiction, concentrating before that time on printing, chiefly, law books. Ramona was among the most important titles added to the catalogue, but the firm was most excited to be able to bring Louisa May Alcott's novels under their imprint. ${ }^{59}$ Ramona was published under their imprint until 1939. The latest date that I have found the first edition plates used is 1912 , which is the second time that the copyright was renewed, by William S. Jackson, the author's second husband. This 1912 edition is printed from the plates of the 1886 edition, the one that has the extra gathering with the Roberts essay.

${ }^{57}$ Kilgour, Roberts Brothers, 261
${ }^{58}$ Kilgour Roberts Brothers, 261
${ }^{59}$ One Hundred Years of Publishing 1837-1937. (Boston: Little, Brown and Company, 1937), 33, 40 
Even while Little, Brown and Company was printing copies of the first edition, a new copyright was obtained in 1900 - the first time the copyright was renewed. With this new copyright came three quite different impressions of the book —all of which are the second edition, that is, printed from the same new type setting. With these books come the most dramatic experiments with space, compared with all other editions of the novel. The first edition clearly made its priority to be economical of space and to save paper; there are few paragraph breaks, no illustrations, and the leading, or the space between the lines of the text, is narrow.

The 1900 second edition copies, however, divide the book into two volumes, making the break between chapter 14 and chapter 15 . This design likely had nothing to do with text itself, but probably occurred in order to make the books more expensive and give them the aura of being collectable. Nevertheless, the break occurs in an opportune place, for chapter 14 ends with a dramatic, romantic climax. Ramona, after being refused permission to marry her Indian love Alessandro by her guardian, has been waiting for Alessandro to return and take her away to be married. When he at last does so, he has a tale of horror to tell. His people have been evicted from his village by white settlers, his friend has been murdered, and all of their assets stolen. Ramona insists that they still be married, even though Alessandro now has nothing. The ending of the chapter is clearly designed to make a reader's heart quake:

Suddenly her heart gave way; and without premeditation, without resolve, almost without consciousness of what she was doing, she flung herself on Alessandro's breast, and cried: "Oh, Alessandro, take me with you! Take me with you! I would rather die than have you leave me again! ${ }^{60}$

${ }^{60}$ Jackson, Ramona, 245 
The chapter, in short, is an apex for Jackson's agenda of using a romantic love story to raise sympathy in her audience; the devastation of Alessandro's people is wrapped in the powerful romantic packaging of Ramona's passionate declaration of love and Alessandro's bitter despair. Dividing the book here into two separate volumes heightens this climax by lengthening its moment of tension, as the reader has to open the next volume in order to continue the story. Interestingly enough, the chapter that is a major turning point for the novel ends exactly at the halfway mark of the book: the novel is 490 pages, and the end of chapter 14 is on page 245.

Is it a coincidence that this moment occurs here, bibliographically, half-way through the book? It is impossible to say whether or not Jackson, or Niles, intended this physical representation of the novel's turning point. For from this point on is a downward trajectory, in which Alessandro and Ramona struggle to support themselves, to find a home, and to lose a child. In the end, Alessandro literally loses his life, while Ramona figuratively loses hers. In this way, the division into two volumes could actually work in favor for Jackson's message_-although it was more than likely an economic and marketing decision to make two volumes. Furthermore, the books would make a more attractive set if they were the same size, that is, if the text was simply divided in half.

I was unable to determine the order of publication for these three sets, so my list of them here is arbitrary chronologically. The first of these sets that I will describe is the Monterey edition, which was bound in blue cloth. It has an introduction by Susan Coolidge (a.k.a. Jackson's friend Sarah Woolsey) and illustrations, as well as a note on his illustrations, by Henry Sandham, who had accompanied Jackson on her trips to California while she wrote travel articles for the Century Magazine. Sandham created 
smaller drawings for chapter headings, created using woodblocks, which were probably printed at the same time that the text was. He also contributed full-page drawings, which were produced planographically and are on a separate, heavier, paper from the paper that the text of the novel is on. The full-page illustrations have two tissue guards, one smaller white one, and one larger tan one that has the title of the drawing printed on it in red ink. Neither of the volumes have advertisements.

While the Monterey edition seems to be aimed towards a middle class audience, the Edition de Luxe possesses an over-the-top lavishness that must have been meant to appeal to the wealthy. Its claim to luxury derives from a combination of obviously rich materials, insinuations of French connections, and aged appearance. Though it was printed from the same plates as both the Monterey and the Pasadena editions, this fact is, perhaps on purpose, disguised by the text being printed on much larger, thicker paper than the other two editions. The edges are uneven, as though just cut apart. It comes in two separate books, as the Monterey does. The illustrations are the same as those in the Monterey edition: they have been done planographically and have two tissue guards. The only difference is that both volume one and volume two feature color frontispieces. It has no advertisements.

The Pasadena edition has the same plates as the Monterey, but was given a very different binding. Though the text is still divided into two volumes, it only comes in one book. For this reason, I posit that it was aimed at audiences who had lesser means, but still the desire to possess a rich-looking book. Sandham's full-page drawings are reproduced photographically and this time do not have tissue guards. It has no advertisements. 
In 1913 a new impression of the book came out, bound very differently once again, and with a new introduction, this time by A. C. Vroman. Adam Clark Vroman was a photographer who took a series of photographs of California Missions and portraits of Native Americans. His introduction traces the genesis of Ramona, emphasizes Jackson's commitment to Native American rights, and links the text with the real events that he explains Jackson wove into her plot. The plates are the same as the 1900 edition, so it is still the second edition of the book, even though it looks very different from the three 1900 impressions. The chapter headings Sandham created remain, but his full-page drawings have been replaced with Vroman's photographs. The photographs have two layers of protective tissue and link quotations from Ramona to actual places in Southern California. Vroman, in emphasizing the real places that inspired the novel, may have inadvertently encouraged growth of the already thriving tourist industry surrounding Ramona.

The third edition was created in 1914, after a 1913 renewal of copyright. It looks quite similar to the first edition in its binding, though the words and flowers are stamped in black rather than in gilt. This edition was printed at least through 1927. A significant event in the life of this edition was the 1916 Ramona movie, the first one that was created. As a result, a significant change appeared in the third edition in 1916: it added a photographic frontispiece that depicted a scene from the movie. Linking it explicitly with the film, of course, would have emphasized the entertainment quality of the novel and perhaps caused audiences to interpret it as the film interpreted the book. The 1927 edition that I examined came with a dust jacket. Presumably, earlier copies of this edition had the dust jacket as well (assuming that the jacket actually did come with that edition and was 
not switched to it from another one), but I could not verify whether or not they did. The dust jacket has Ramona on the front, and Alessandro on the back, which was no doubt meant to symbolize their tragic separation.

In 1932, Little, Brown and Company renewed the copyright and came out with yet another new edition. It has no introduction, but does feature new illustrations, done by Herbert Morton Stoops, a famous and highly sought after artist at the time. There is an illustration at the beginning of each chapter, a pastel-colored frontispiece at the beginning of the book, and some drawings interposed within the text and at the end of chapters. One copy was specifically geared towards children: its dust jacket declares that "this book has been chosen by the Editor of the Junior Literary Guild... as the selection for August, 1932, sent to Older Girls." This is the first of three different impressions in the book's history that would be geared towards children.

In 1934, Grosset and Dunlap began publishing the book, apparently using new plates; in any case, they are not the same as the 1932. Because they are usually a firm that reprints previous editions, it is quite possible that the plates they used were either based on the 1914 plates, or are the 1914 plates. At this point, then, it is questionable as to whether or not this book constitutes a different edition, though it is more likely that it has a new typesetting based on the 1914. That the 1914 plates are the basis for the book is indicated by the presence of a comma after "Southern California" in the first line instead of a semi-colon (the 1913 still has the semi-colon broken off, as does the 1912; the 1914 replaced that broken piece with a comma). Instead of using the Stoops illustrations, it uses the original Sandham chapter head illustrations from 1900. The publishers reused 
these plates at least through 1961, though over the years they released the book in different dust jackets.

The 1936 Grosset and Dunlap capitalizes on the movie made that year with a dust jacket featuring Loretta Young. The 1940 Grosset and Dunlap has a different binding and a different dust jacket, but uses the same plates. The dust jacket illustration is the same as that for the 1927, but the text on the inside flaps comes from the 1934 dust jacket. The 1961 Grosset and Dunlap came out with a new dust jacket, which has an illustration of Ramona sitting on a mule being led by Alessandro down a canon path.

Interestingly, the last impression that Little, Brown and Company published in 1939 used the 1934 Grosset and Dunlap plates as well, versus using their own plates. The book did, however, feature new illustrations, this time by N. C. Wyeth, as well as a new introduction, by May Lamberton Becker. It also came in an olive green dust jacket, with a large color drawing of Wyeth's. This impression appeared at least through 1951.

Triangle Books came out with a new impression of the book in 1941 with a new dust jacket, but the plates used were once again the 1934 Grosset and Dunlap. As Triangle Books advertised on the dust jacket that the main virtue of the book was its cheapness, this choice of plates is hardly a surprise. They even say proudly that that it was "printed complete from the expensive plates of the original $\$ 2.00$ and $\$ 2.50$ editions!"

In the midst of all these 1934 plate impressions that continued into the 1960's, a new edition did come out in 1944. Books Inc. created their own plates and even corrected the comma after "Southern California" in line one into a semi-colon. They offered the book in a new, very romantic, jacket. A large illustration of Ramona, in traditional 
Mexican dress, has her gazing dreamily upwards, her hands crossed on her chest, against a background of the night sky. It is surely meant to sell readers on the love story, and to symbolize that Ramona's longing for her lost husband is never satisfied. In this way, it subordinates Jackson's activist message.

The second of the editions aimed at children (the first being the 1932 Junior Literary Guild) came out in 1952 and was published by Globe Books. This time, the text was abridged by Olive Eckerson. The changes were mostly making sentences shorter, substituting some of Jackson's difficult punctuation for simpler marks, and adding titles for each chapter. The third and final edition for children came out in 1973 and was abridged by Nora Kramer.

In 1959 a luxurious edition was created for the Limited Editions Club. It came in its own box and was signed by the illustrator. Even as the Edition de Luxe did back in 1900 , there is a special page stating that only a certain number of editions had been printed, and there is a handwritten number indicating which of those editions the owner was in possession of. Once again, luxury is implied through the emphasis on rarity. In 1981 a new paperback edition came out, which was published by Pinnacle Books. It has a striking front cover, for it was made to fit the spirit of the times; the illustration of Ramona on the binding is reminiscent of Jane Fonda. Interestingly, Pinnacle Books made it more attractive by offering it in a set of two volumes, the other being the sequel to Ramona written that year: Ramona's Daughter, by Virginia Myers.

In 1988, Penguin published Ramona as a part of their Signet Classic series. It features an introduction by Michael Dorris. Penguin used the same type setting in its 2002 publication of the novel. The main differences between them are a different 
illustration for the binding, and the addition of a new afterword, by Valerie Sherer Mathes. Mathes is one of the most prominent Helen Hunt Jackson scholars today; she has several books on Jackson, including the volume of Jackson's letters that she edited. In 2006, Penguin once again released a copy of the same edition, again with a different illustration for the binding, but with no other new features.

In 2005, the Random House Publishing Group came out with an edition of Ramona, under the imprint "Modern Library Paperback Edition." It includes several extra features: a biographical note of Jackson, an introduction by Denise Chavez, a note on the text, and an English translation by Esther Allen of the Introduction to the 1888 Spanish edition, which was translated and published by Jose Marti. The notes were written by Andrea Tinnemeyer and there is also a reading group guide. Chavez writes about her own conflicted reading experience of the novel and about her thoughts on its continued relevance. It seems to be present as the publisher's solution of how to get a modern reader over the obstacle presented by Jackson's sentimental style, as Chavez explains, despite her aversions to the way it was written, she ended up enjoying the book and believing in its importance. The binding emphasizes the connection with Jose Marti by featuring a quotation from him. The photograph on the binding unusually does not feature a location in Southern California or a romantic picture of Ramona herself: it has the picture of a back of a generic girl's head and the single braid that goes down her back.

The type setting created in 2008 is the most recent printed edition of the novel that has been created. It is edited by Siobhan Senier. Aside from the flaws with the text, which I explore in the textual commentary, the edition does include useful historical background and documents. Its goal was less to capture Jackson's final intentions for her 
text, than to give, students especially, a sense of the context of Indian Reform that surrounds the novel. 


\section{Works Cited}

\section{Primary Sources}

Jackson, Helen. Ramona. Helen Hunt Jackson Papers. Tutt Library, Colorado College, Colorado Springs, Colorado. Box 4, HHJ Papers, Part 1, Ms 0020.

Jackson, Helen. "Ramona.” Christian Union (1870-1893), May 15, 1884. 462-464, http://search.proquest.com/docview/137053429?accountid=14678 (accessed April 11, 2014).

Jackson, Helen. “Ramona.” Christian Union (1870-1893), Nov 06, 1884. 441-444. http://search.proquest.com/docview/137067012?accountid=14678 (accessed April 11, 2014).

Jackson, Helen. Ramona. Boston: Roberts Brothers, 1884.

Jackson, Helen. Ramona. Boston: Roberts Brothers, 1886.

Jackson, Helen. The Hunter Cats of Connorloa. (Boston: Roberts Brothers, 1884)

Jackson, Helen Hunt. The Indian Reform Letters of Helen Hunt Jackson, 1879-1885.

Valerie Sherer Mathes, ed. Norman: University of Oklahoma Press, 1998. Print.

\section{Secondary Sources from within Ramona Editions}

Chávez, Denise. Introduction to Ramona. New York: The Random House Publishing Group, 2005.

Senier, Siobhan. "A Note on the Text” in Ramona. Buffalo: Broadview Press, 2008.

Sandham, Henry. Note about Illustrations in Ramona. Pasadena edition. Little Brown and Company, 1900.

Textual Note in Ramona. New York: the Random House Publishing Group, 2005. 


\section{Secondary Sources}

DeLyser, Dydia. Ramona Memories. Minneapolis: University of Minnesota Press, 2005.

Hart, James D. The Popular Book: A History of America's Literary Taste. New York: Oxford University Press, 1950.

Irwin, Robert McKee. "Ramona and Post Nationalist American Studies: On 'Our America' and the Mexican Borderlands". American Quarterly. 55.4 (December 2003): 539-567.

Kilgour, Raymond L. Messrs. Roberts Brothers Publishers. Ann Arbor: University of Michigan Press, 1952.

Mott, Frank Luther. A History of American Magazines, 1741-1930. 5 vols. Cambridge: The Belknap Press of Harvard University Press, 1958.

Moylan, Michelle. "Materiality as Performance: The Forming of Helen Hunt Jackson's Ramona," in Reading Books: Essays on the Material Text and Literature in America. Michelle Moylan and Lane Stiles, eds. Amherst: University of Massachusetts Press, 1996.

Odell, Ruth. Helen Hunt Jackson. New York: D. Appleton-Century Company, 1939.

One Hundred Years of Publishing 1837-1937. Boston: Little, Brown and Company, 1937.

Phillips, Kate. Helen Hunt Jackson: A Literary Life. Berkeley: University of California Press, 2003.

Tanselle, G. Thomas. "Editing Without a Copy-Text.” In Literature and Artifacts. Charlottesville: The Bibliographical Society of the University of Virginia, 1998.

Tanselle, G. Thomas. Guide to the Study of United States Imprints. (Cambridge: Belknap Press of Harvard University Press, 1971. 